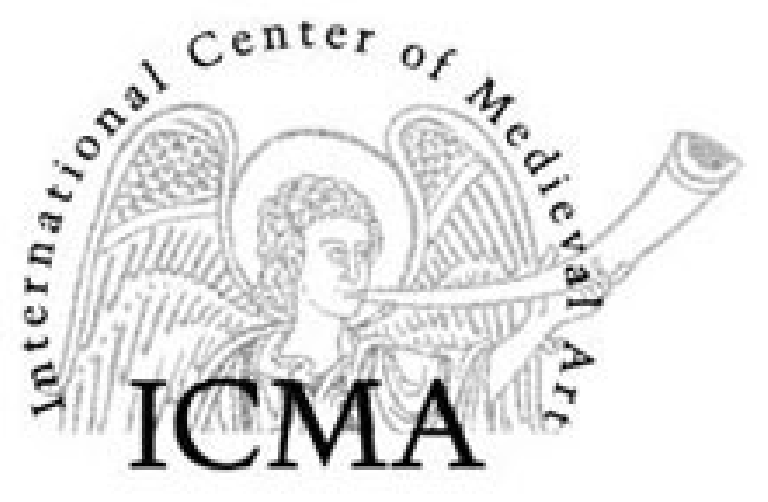

Synagoga Tumbles, a Rider Triumphs: Clerical Viewers and the Fürstenportal of Bamberg Cathedral

Author(s): Nina Rowe

Reviewed work(s):

Source: Gesta, Vol. 45, No. 1 (2006), pp. 15-42

Published by: International Center of Medieval Art

Stable URL: http://www.jstor.org/stable/25067124

Accessed: 05/06/2012 12:09

Your use of the JSTOR archive indicates your acceptance of the Terms \& Conditions of Use, available at http://www.jstor.org/page/info/about/policies/terms.jsp

JSTOR is a not-for-profit service that helps scholars, researchers, and students discover, use, and build upon a wide range of content in a trusted digital archive. We use information technology and tools to increase productivity and facilitate new forms of scholarship. For more information about JSTOR, please contact support@jstor.org. 


\section{Synagoga Tumbles, a Rider Triumphs: Clerical Viewers and the Fürstenportal of Bamberg Cathedral*}

NINA ROWE

Fordham University

\section{Abstract}

Paired female personifications of Church and Synagogue had become an established subject for medieval art from as early as the ninth century. But in the thirteenth century the theme gained particular popularity, given pride of place in decorative programs adorning the most ambitious cathedral building projects of northern Europe. While the figures continued to carry established meanings that manifested both the ecclesiological notion of the harmony between the Old and New Testaments and the triumph of Christianity over Judaism, monumental, lifelike instantiations of the theme in the new context of the cathedral facade invited interpretations in relation to contemporary secular and sacred ideologies of power. This article argues that in the eyes of Bamberg's clerics, ceremonial movement through the Fürstenportal of Bamberg Cathedral activated new meanings for the EcclesiaSynagoga motif, binding the figures to the Bamberg Rider sculpture within the building. The bishops and chapter of Bamberg were strong adherents of Emperor Frederick II, whose policy and ideology hinged in part on notions of the correct position of Jews in society. Viewed during a ritual entrance to the cathedral, an aestheticized yet impotent figure of Synagoga, along with the larger constellation of sculptures at the Fürstenportal, could project and reinscribe conceptions of Jews as fundamentally base, yet necessary, cogs in the machinery of a divinely ordered society.

On 6 May 1237 the city of Bamberg celebrated the consecration of its newly rebuilt cathedral. Perched high on a hill at the center of town and punctuated by four imposing towers, the new structure loomed over the civic space in the valley below (Fig. 1). Now known as the Fürstenportal, the chief ceremonial entryway at the building's north side was lavishly adorned with sculptures (Figs. 2 and 3). ${ }^{1}$ Deeply carved figures in dramatic poses inhabit its tympanum, offering a pantomime performance of the separation of the saved and the damned at the Last Judgment. Wedged into the door jambs below, apostles stand on the shoulders of prophets; both strain to look up and catch a glimpse of the sacred drama in the tympanum. Hovering at the base of the portal's left archivolts, a trumpeting angel announces Christ's Second Coming, and a figure of Abraham sits enthroned, cradling the souls of the saved. Two monumental, freestanding female personifications of a triumphant crowned Church and a blindfolded, wilting Synagogue-
Ecclesia and Synagoga - flank the ensemble, each installed atop a column, beneath a baldachin. Ecclesia's column is adorned with a seated figure and symbols of the evangelists; Synagoga's features the Devil blinding a Jew.

This vision of cosmic adjudication and celestial order was available to all members of Bamberg's urban community and to visitors to the city, though it appears to have been created primarily for the rarified audience of the bishop, his household, the chapter, and guests of the episcopacy. ${ }^{2}$ In the thirteenth century the episcopal precinct consisted of the cathedral itself, the bishop's palace to the northwest, and the canonical buildings and cloister attached to the cathedral's south side (Fig. 4). ${ }^{3}$ It seems that the plaza that stretches before the cathedral's north side today (bounded to the north by one arm of the seventeenth-century Neue Residenz, now the Staatsbibliothek) existed in a similar form in the thirteenth century. This whole precinct apparently was enwalled, though presumably still accessible to those who entered its eastern and western gates. There were occasions when Bamberg's urban population could have visited the cathedral hill and seen the Fürstenportal. For example, when the bishop of Bamberg held his court in the square at the north side of the cathedral, canons, clerics from local collegiate churches, and, possibly, members of the city's ministerial and burgher population could gaze at the Fürstenportal and reflect on themes of justice and retribution. ${ }^{4}$ City dwellers could also pass the Fürstenportal if they had business that brought them up from the mercantile center in the valley below, to the collegiate church of Saint Jacob or the monastery of Saint Michael, two foundations also on promontories beyond the cathedral hill. Such viewers may have meditated on the virulent anti-Jewish polemic likely preached by local Franciscans as they looked up at the sculpture of Synagoga or the Devil blinding a Jew on the pillar beneath her. ${ }^{5}$ The Jews of Bamberg who served ecclesiastical clients through the money trades also would have seen the sculptures. Members of this audience perhaps scoffed at the cathedral's loose interpretation of the Second Commandment prohibition on graven images while also viewing the portal's victimized Jew and decrepit Synagoga with anxiety over the anti-Jewish violence the images might ignite.

The Fürstenportal did not, however, address itself primarily to the laity. This ceremonial entrance was on the building's north side, whereas it was the east end of the building 


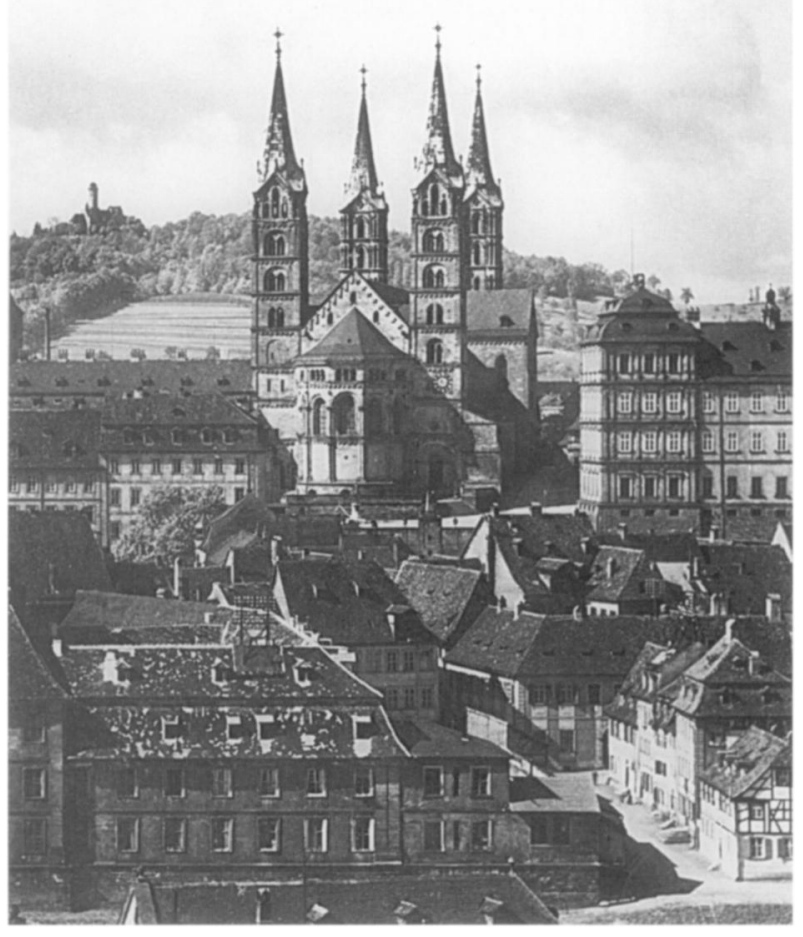

FIGURE 1. Bamberg Cathedral from the city center (photo: Foto Marburg / Art Resource, NY).

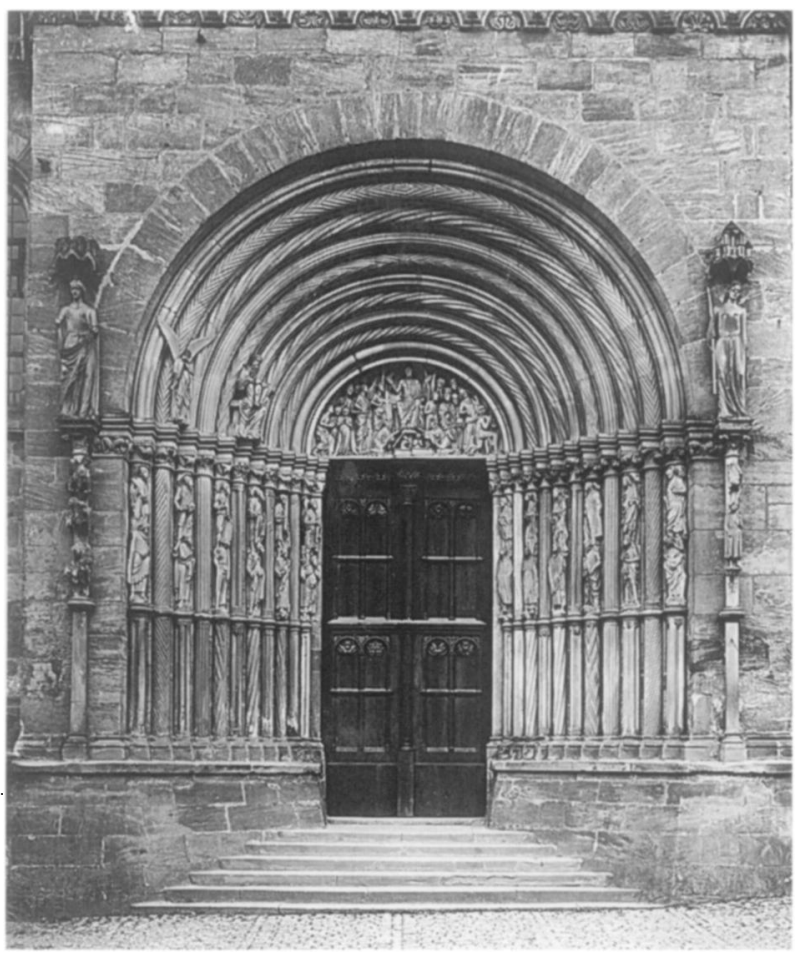

FIGURE 3. Fürstenportal. North facade, Bamberg Cathedral (photo: Foto Marburg / Art Resource, NY).

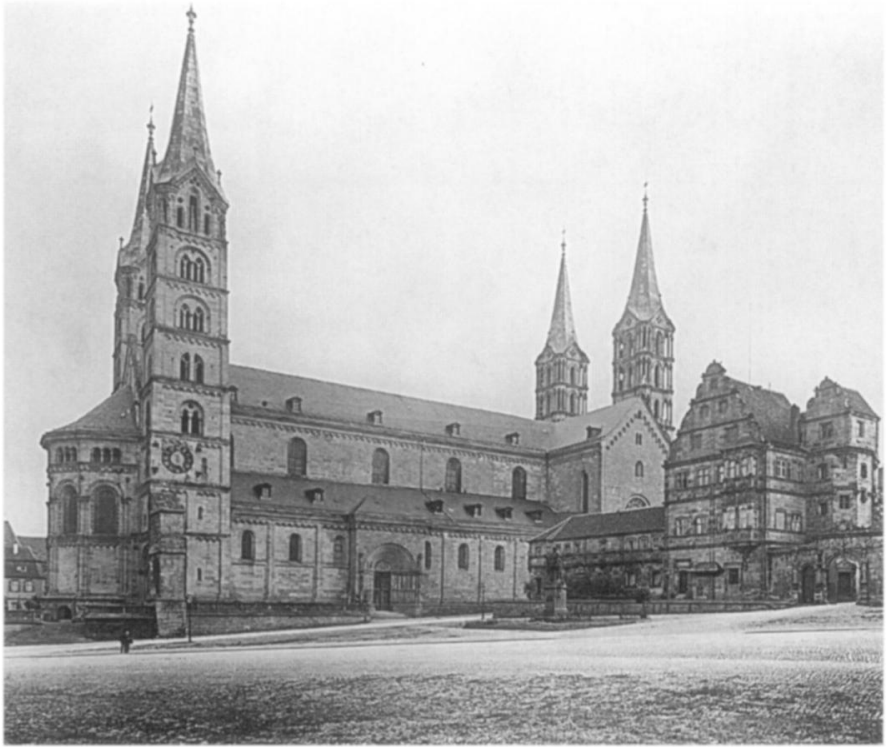

FIGURE 2. Bamberg Cathedral from the north (photo: Foto Marburg / Art Resource, $N Y$ ).

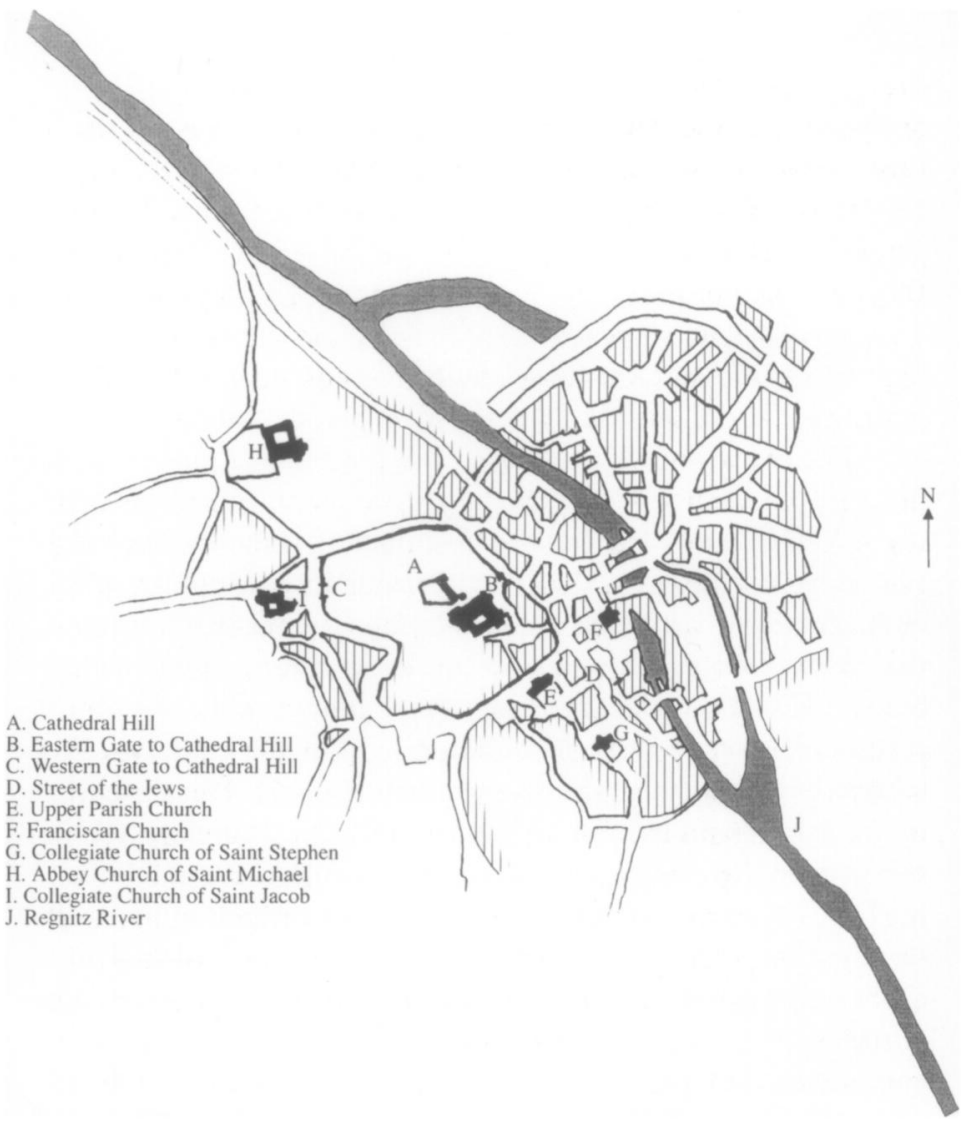

FIGURE 4. Plan of Bamberg's cathedral hill and western portion of the city (by the author with assistance from Wes Evard, 2006, after Schimmelpfennig). 


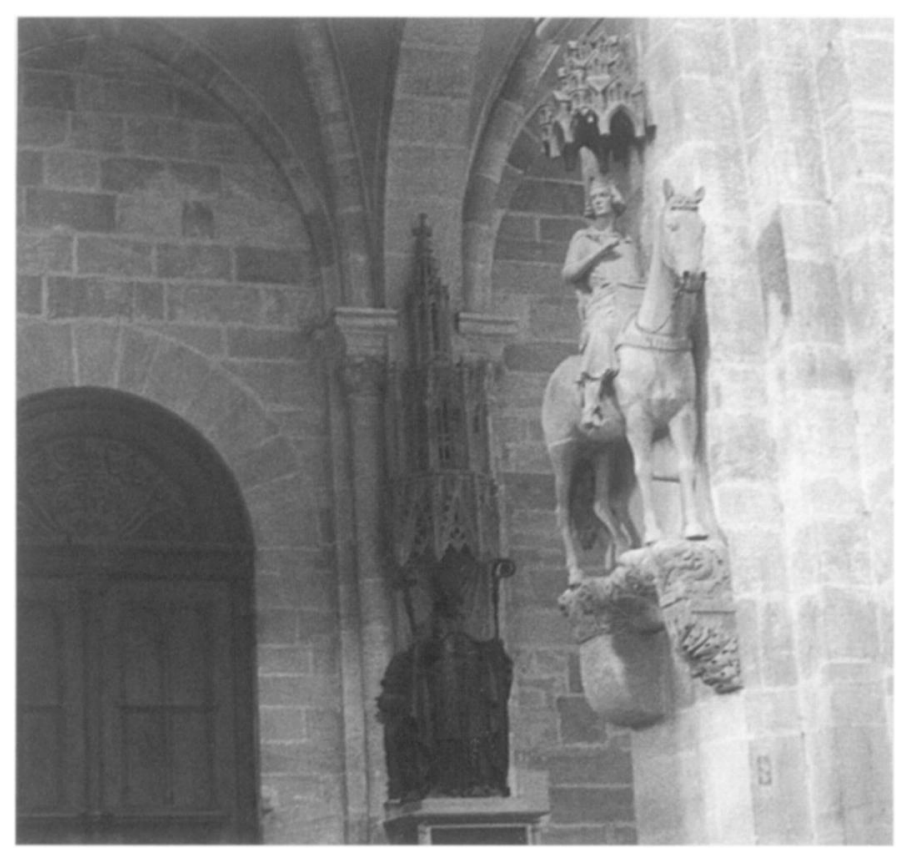

FIGURE 5. Bamberg Rider installed on northern pier, east end, Bamberg Cathedral (photo: Foto Marburg / Art Resource, NY).

that greeted visitors who walked up the cathedral hill. ${ }^{6}$ Scholars posit that the south portal of the building's eastern face (known as the Adamspforte) was created especially as a site for lay penitential rituals and to serve as an entrance for pilgrims traveling to Bamberg to honor its recently canonized founders Emperor Henry II and Empress Kunigunde. ${ }^{7}$ The citizens of Bamberg seem to have visited the cathedral only on high feast days and relied for spiritual needs such as baptisms, marriages, and death services on their parish churches. ${ }^{8}$

The clerics of the cathedral and their select guests were the principal audience for Bamberg's ceremonial entrance, and, it seems, the only audience permitted to walk through the Fürstenportal and, as a result, experience its exterior program in conjunction with the cathedral's interior decor. Only they would see that the portal program is complemented, indeed completed, by the equestrian sculpture known as the Bamberg Rider affixed to a pier at the eastern end of the cathedral directly inside the ceremonial entryway (Fig. 5). During ceremonial processions at the cathedral hill, the Bamberg Rider served to draw members of the clerical retinue into the building and to introduce them to the sacred order represented within. ${ }^{9}$ The Bamberg Rider, a representative of earthly authority, gained meaning in relation to the figures on the portal exterior - the scene of the Last Judgment and the personifications of the Church and the Jewish tradition. ${ }^{10}$ Similarly, because of their juxtaposition with the Rider, Ecclesia and Synagoga invite emphatically political interpretations. ${ }^{11}$

Earlier scholarship on the Ecclesia-Synagoga motif ignored its political significances. ${ }^{12}$ Key surveys on the theme explain the paired personifications of Church and Synagogue as a pictorial means to convey either the theological notion of the harmony between the Old and New Testaments or the triumph of Christianity over Judaism. These iconographic studies are useful because they analyze a range of instances of the theme of Ecclesia and Synagoga across multiple media throughout the Middle Ages and amass a body of related theological texts. But this literature suffers from some of the shortcomings endemic to iconographic analysis in general. ${ }^{13}$ Tracking gestures, attributes, and only occasionally the visual contexts of the figures, questions regarding scale, style, patronage, and particularly viewership tend to be unexplored. ${ }^{14}$

Studies of Bamberg Cathedral, for their part, typify longstanding trends in the field of medieval art history. Previous analyses of the building's architecture were largely concerned with chronology and style, mentioning the sculpture only in passing. ${ }^{15}$ Discussions of the sculpture emphasized connoisseurship, distinguishing between multiple hands who worked at the site. ${ }^{16}$ Particular attention was paid to differentiating production of the "older" workshop, responsible for the reliefs at the interior eastern choir (Georgenchor) and the northeast portal (Gnadenpforte), from that of the "younger" workshop that came to Bamberg around the 1220 s, perhaps after having been at the Reims work site, to complete the Fürstenportal and other figures. ${ }^{17}$ In an important recent article, Robert Suckale assesses the production at the Bamberg work site, demonstrating that the sculptures were created to be seen from multiple vantage points and calling for further analysis of the way the works address viewers. ${ }^{18}$ Suckale's insights, along with other recent studies that consider the political and social as well as the scopic contingencies of medieval viewership, are departure points for the present study. ${ }^{19}$

In this article, I seek to reconstruct the viewing experience of the elite group of clerics who were permitted to walk through the Fürstenportal into the cathedral and proceed to their designated seats at the building's high choir, the western Peterschor. Borrowing a term from reception theory, I consider these clerics and their adherents as a principal "interpretive community" for the decorative complex. ${ }^{20}$ That is, in the high Middle Ages, monumental visual programs often were created to appeal to a variety of audiences, with a range of experience with and investment in the theological and ecclesiological abstractions that drove iconographies. Collective identities of such groups often crystallized around a shared "horizon of expectations," forged by social, intellectual, and corporate experience. At Bamberg, the local Jewish community, the city's burghers, pilgrims honoring the cults of SS. Henry and Kunigunde, among others, each constituted a separate interpretive community, distinct from that of the cathedral's clerics. Sensitivity to the varied worldviews informing reception in general can help scholars analyze systematically the multivalence of premodern decorative programs.

In the discussion that follows, I consider the political, theological, and social conditions that constituted the Bamberg 
clerics' horizon of expectations as they viewed the Fürstenportal. These expectations were driven by historical circumstances and the ideological commitments of the clerics' overlord, Bishop Ekbert von Andechs-Meran (1203-1237). Bishop Ekbert ruled during much of the time that the cathedral building project was under way. He was the magnate under whom the Fürstenportal was created and the leader whose political alliance to Emperor Frederick II shaped the cathedral's decorative program.

Ekbert's clerics certainly may have deviated from the bishop's official positions and likely oversaw much of the cathedral's construction. Indeed, Bishop Ekbert was away from Bamberg on the day of the ceremonial consecration of the cathedral in 1237. He was in Austria, fighting on behalf of his imperial overlord. Ekbert died within a month of the cathedral's dedication, never having returned to Bamberg to see the building project completed. Ekbert's successor, his uncle, Poppo von Andechs-Meran (provost 1206-1237; bishop 1237-1242), was the first Bamberg bishop to enjoy full use of the Fürstenportal, and the clerics under Poppo's leadership were the ones who experienced the site as an integrated image environment. But the early reign of Bishop Poppo is marked by continuities with rather than breaks from the previous regime. Poppo had been the provost of the cathedral throughout Ekbert's reign, and when he became bishop he continued his nephew's political affiliation with the Hohenstaufen. ${ }^{21}$ The cathedral clerics, for their part, at times disagreed with Ekbert, but it was only after the era of Ekbert and Poppo, in the late thirteenth and fourteenth centuries, that the Bamberg chapter forcefully asserted its independence from the bishop. ${ }^{22}$ If clerics at Bamberg periodically resented or even renounced the absolute authority of their episcopal overlord, by dint of their office they still were immersed in the historical circumstances and versed in the prevailing imperial ideologies that officially informed clerical production and reception of the Fürstenportal.

Recovery of the original sensory effects of the works at Bamberg is a challenge. In the nineteenth century, the polychromy was stripped off the sculptures and the walls at Bamberg Cathedral. ${ }^{23}$ In 1936 the building underwent further transformation when the sculptures of Ecclesia, Synagoga, the trumpeting angel, and Abraham were removed from their original posts on the Fürstenportal exterior. ${ }^{24}$ Currently they are installed at the east end of the cathedral's interior south aisle, perched on raised plinths that approximate the height of the original columns on which the figures stood. ${ }^{25}$ Because visuality is contingent, no twenty-first-century scholar can fully re-create a thirteenth-century imagistic encounter. ${ }^{26}$ But it is worth trying to estimate the original scopic experience of Ecclesia and Synagoga in relation to their decorative environment, because it will lead to a better understanding of medieval uses of the notion of the Jew and of the coercive power of lifelike style and aestheticization.

\section{An Episcopal Agenda}

On the day of the cathedral consecration in 1237, Bamberg's canons had much to celebrate. Over the previous half century their city had been transformed from a cultural backwater and a site of fluctuating political fortunes to a center of power within the empire. Located in Franconia, in the northern part of the modern state of Bavaria, Bamberg was established in 1007 by Emperor Henry II, who founded the city as seat of a new bishopric and as putative administrative and spiritual center for his rule. ${ }^{27}$ Following Carolingian and Ottonian precedents at cities such as Aachen and Magdeburg, Henry II endowed Bamberg with extensive holdings, showered the new see with luxury manuscripts and liturgical objects, and ordered the construction of a lavish cathedral. ${ }^{28}$ Throughout Henry II's reign Bamberg hosted multiple secular and ecclesiastical celebrations and was a favored visiting spot for the itinerant imperial court. But following Henry's death in 1024, imperial interest in Bamberg dwindled. For close to a century and a half the city strengthened its religious hold over the region and flourished economically, but in this era, the bishops of Bamberg had only weak ties to the empire, and the city rarely was visited by the imperial retinue.

With the episcopal election of Otto II von AndechsMeran (1177-1196), however, Bamberg's period of insularity ended. Otto II was one of Emperor Frederick Barbarossa's closest ecclesiastical allies and was deeply involved in imperial politics in the 1180s and 1190s. Otto II's great-nephew Ekbert von Andechs-Meran enhanced Bamberg's transregional élan further. As spiritual and temporal lord, Bishop Ekbert aggressively sought to restore his see to the transregional status it had enjoyed at its founding. As a member of one of the most powerful noble lines in Germany, Ekbert was able to cement new connections between Bamberg and power centers across northern Europe. ${ }^{29}$ His siblings were among the strongest ecclesiastical and secular princes of the empire, and his family administered territories throughout Franconia, Bavaria, the Tyrol, and Carniola. Moreover, thanks to the shrewd diplomacy of his family, Ekbert was brother-in-law to King Philip Augustus of France and King Andrew of Hungary.

In 1208 Ekbert sought to augment further the prestige of his line, himself, and his see by brokering the marriage of his brother to the niece of the German king, Philip of Swabia (1198-1208). Ekbert arranged to have the wedding held at Bamberg, and dignitaries from across the German territories traveled to the city to honor the union. But while Ekbert expected the nuptial festivities to win him honor, they only brought disgrace. ${ }^{30}$ On the wedding day, after presiding over the exchange of vows, King Philip retired to the bishop's palace, where he was assassinated by Otto von Wittelsbach, palatine count of Bavaria.

Bishop Ekbert, his brother Henry of Istria, and the episcopal ministeriales were implicated in the murder, for it was 


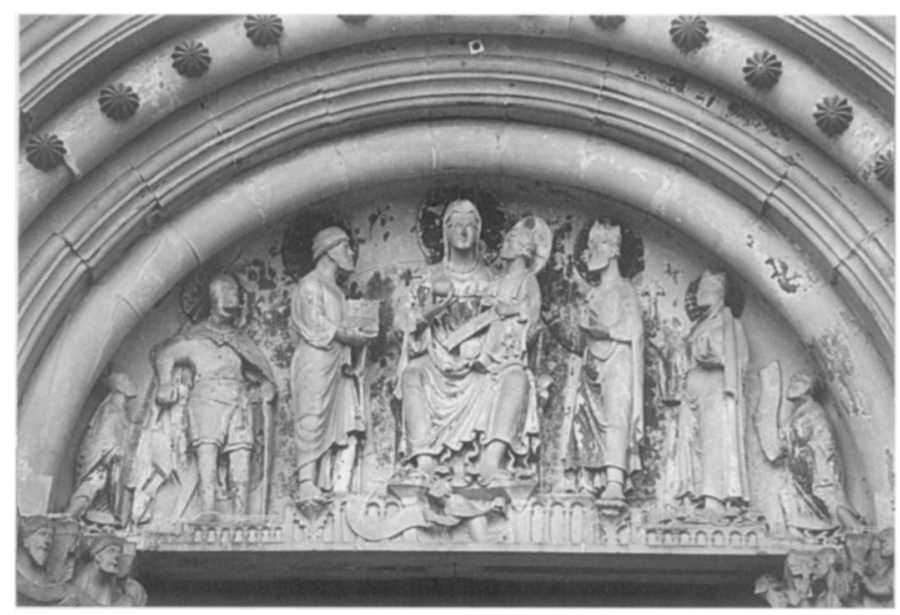

FIGURE 6. Virgin and Child with SS. Henry, Kunigunde, George, Peter, and ecclesiastical figures, Gnadenpforte, Bamberg Cathedral (photo: author).

apparent that without the assistance of an intimate who knew the intricacies of the episcopal palace and the precise whereabouts of the king during his stay at Bamberg, Otto von Wittelsbach could not have carried out his attack. However, contemporary sources contradict one another over the degree of Ekbert's involvement. Some suggest that the bishop lured Philip into the designated spot of the murder or helped Otto von Wittelsbach escape. Others say only that the bishop's men took part in the bloody assault, though one source even doubts Ekbert's participation altogether ${ }^{31}$ Recent scholarship concludes that the bishop did conspire in the murderous plot, welcoming the assassination of Philip, because the king refused to renounce his claims to fiefs included within Bamberg's holdings. ${ }^{32}$ Whatever the actual extent of their involvement, the bishop and Henry of Istria aroused suspicions because they fled Bamberg for the safety of the Hungarian royal court, where their sister Gertrud was queen. ${ }^{33}$ At an imperial diet of November 1208, when Otto of Brunswick was elected king of Germany, the princes of the realm ruled that Ekbert should be tried without an investigation. Shortly thereafter the bishop was condemned and given the same harsh sentence as the known murderer, Otto von Wittelsbach. Bishop Ekbert lost all his fiefs and taxation authority over his allodial lands, his title was revoked, and the Bamberg chapter was put under the administration of King Otto IV. For more than three years Ekbert remained in exile. But eventually he forged an alliance with Pope Innocent III, and in 1211 he was acquitted and restored to office. ${ }^{34}$

Once Ekbert was reinstalled as bishop, he used the cathedral as a monument to assert his recovered authority. The cathedral constructed at the order of Emperor Henry II had been damaged by successive fires in the twelfth century. After a particularly large conflagration in 1185 , a rebuilding campaign advanced in fits and starts to create an enlarged copy of Henry's cathedral, with choirs at the east and west ends. ${ }^{35}$ New evidence analyzed by Achim Hubel and Manfred Schuller suggests that the eastern choir was rebuilt by about 1201 , and, following a break in construction about 1210 , the eastern part of the cathedral's north aisle and the Fürstenportal were complete by $1225 .{ }^{36}$ Construction of the western portion of the building was interrupted by another fire about 1227 but was complete by the time of the consecration in $1237 .{ }^{37}$

The sculpture adorning Bamberg Cathedral was created by two teams of sculptors. The first team carved the interior relief sculptures located on the north and south sides of the Georgenchor at the cathedral's east end and the sculpture at the northeastern Gnadenpforte (Fig. 6). They then crafted most of the jamb figures at the Fürstenportal. Midway through the project, a new team of sculptors came to the Bamberg work site, introducing a sculptural style associated with Reims. ${ }^{38}$ Scholars disagree over the precise dating of the arrival of this "younger" workshop. While some have argued that they came to Bamberg as late as 1235 , recent archaeological and historical evidence suggests they may have arrived in the $1220 \mathrm{~s}^{39}$ The "younger" workshop carved most of the Fürstenportal tympanum, some of the right jamb figures, Ecclesia, Synagoga, and the Bamberg Rider. The team also created the sculptures that now adorn the southeastern Adamspforte, the freestanding works now installed around the Georgenchor inside the cathedral, and the tomb of Pope Clement II in the west choir. ${ }^{40}$

Work on the bishop's ceremonial entrance, the Fürstenportal, was under way during the years that Ekbert sought to restore respect for himself and his see through adherence to his imperial overlord. Following Philip of Swabia's murder, Otto of Brunswick secured the German crown, but had a tentative hold on it. Staufen adherents recovered power quickly and elected Frederick II as their new ruler. Bishop Ekbert supported Frederick II, attending Frederick II's coronation in Aachen in 1215 and becoming one of the first to take up the cross when Frederick called for a new crusade. ${ }^{41}$ While Frederick delayed his campaign to the east until 1228, Bishop Ekbert fulfilled his vow right away, departing with the first contingent of the Fifth Crusade in a public display of penitence and of support for his Staufen overlord. ${ }^{42}$ Ekbert's time as a crusader, though, was brief, and by May 1218 the bishop was back in Bamberg. ${ }^{43}$ Meanwhile, up on the Bamberg Cathedral hill, work continued apace. There had been a break in the building project, presumably because of Ekbert's outlaw status and the seizure of episcopal lands and revenues between 1208 and 1211. Within years of his reinstatement, though, work seems to have picked up again, so that by the time the bishop returned from crusade, much of the eastern end of the building was complete. In the years between 1218 and 1223, Ekbert stayed close to home, leaving the city only to go as far away as the Rhineland. ${ }^{44}$ Presumably in these years he invited the "younger" sculptural team to Bamberg, and they set to work on the figures outside and inside the Fürstenportal. 


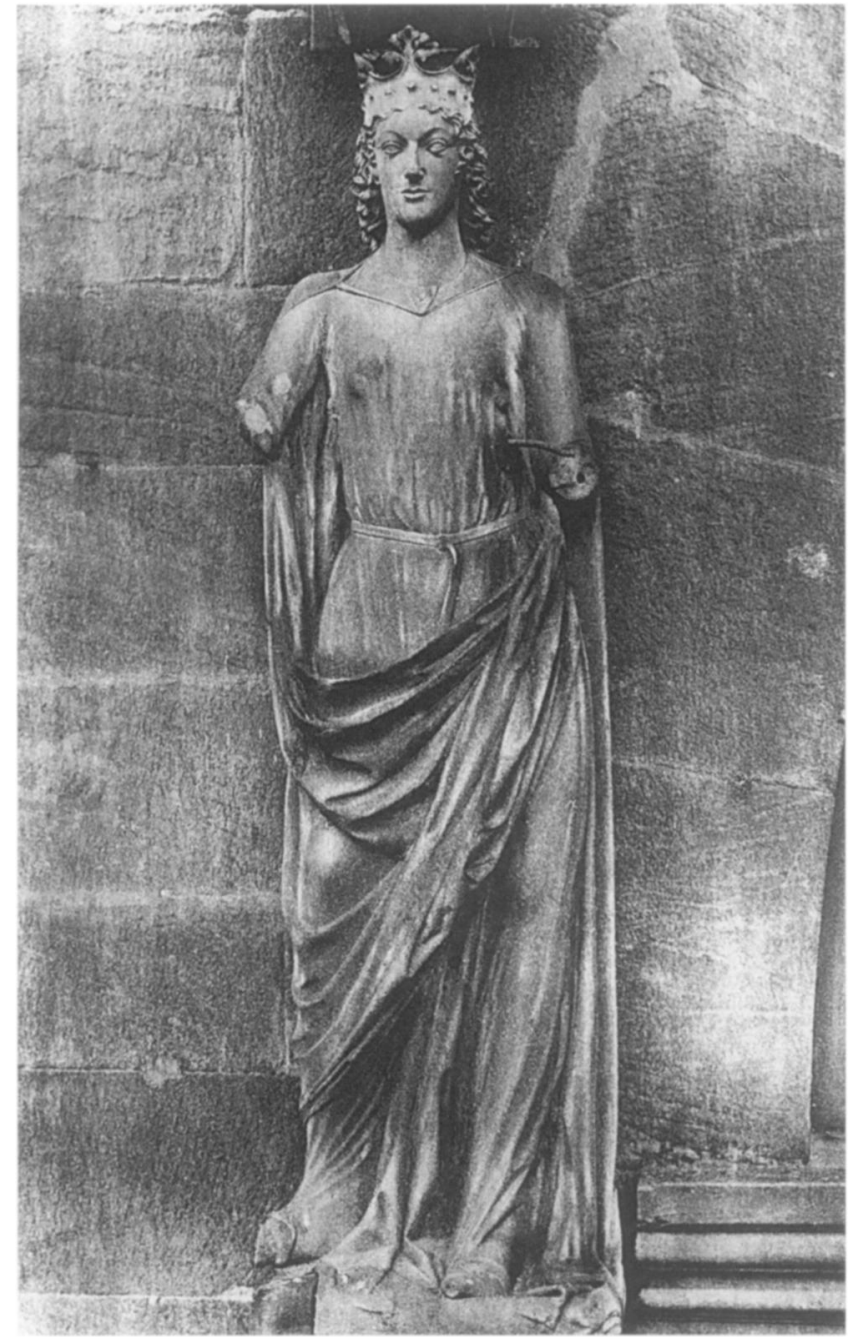

FIGURE 7. Ecclesia, Fürstenportal (formerly), Bamberg Cathedral (photo: Foto Marburg / Art Resource, NY).

In 1225 Ekbert struck a deal that both cemented his ties to the imperial crown and ensured the continued progress of the cathedral's construction. Under the terms of a contract concerning some contested fiefs, Emperor Frederick II granted Ekbert four thousand silver marks. ${ }^{45}$ Most of the money likely went toward the cathedral building project, which by this time was half complete. While it may be too much to say that the settlement resulted in Frederick II's direct support for Bamberg's new cathedral, it was the only church north of the Alps built thanks to an influx of cash from the emperor's fiscum. ${ }^{46}$ At the very least, Ekbert's settlement with Frederick II demonstrates that by the mid-1220s Ekbert could claim a particularly close relationship to the emperor, and the cathedral could serve as a monument to the restoration of Bishop Ekbert's status within the imperial realm. Evidence concerning an altar in the southern arm of the west crossing, dedicated to the Virgin in 1229, demonstrates Ekbert's per-

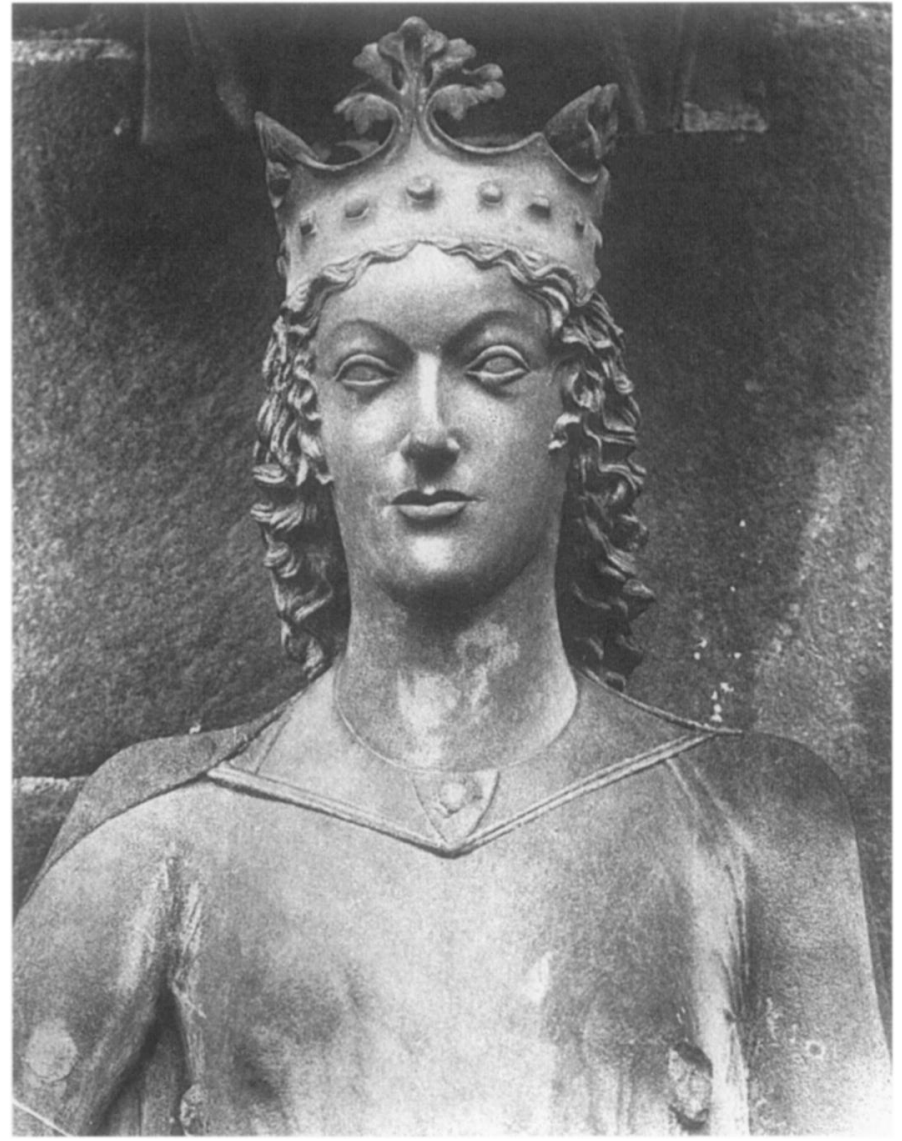

FIGURE 8. Bust of Ecclesia, Bamberg Cathedral (photo: Foto Marburg / Art Resource, NY).

sonal investment in the building and its construction. ${ }^{47}$ The altar was designated to the memory of a certain Wortwinus, apparently the deceased master of the building workshop. There must have been some dispute concerning who had authority to use the site, because a document of 1231 insists that it was Bishop Ekbert alone-neither the provost, nor the deacon, nor any other clerics-who could act as priest at this altar. ${ }^{48}$

If Bishop Ekbert were responsible for reinvigorating the cathedral building project and for bringing sculptors to the site, it was up to the chapter to oversee the building's progress. For in the final years of the construction of Bamberg Cathedral, the bishop was more caught up in cementing his personal relation with Emperor Frederick than with the mortar and masonry of the cathedral going up in his city. In 1225 Ekbert spent roughly six full months in Frederick II's kingdom of Sicily, serving as ambassador on imperial missions. ${ }^{49}$ When Pope Gregory IX excommunicated Frederick II in September 1227 for having delayed too long the fulfillment of his crusading vow, Ekbert was there to garner allies for the imperial cause. The bishop toured the Italian lands with the imperial retinue repeatedly in the early 1230 s. Later in that decade, the emperor rewarded Ekbert with the governorship 


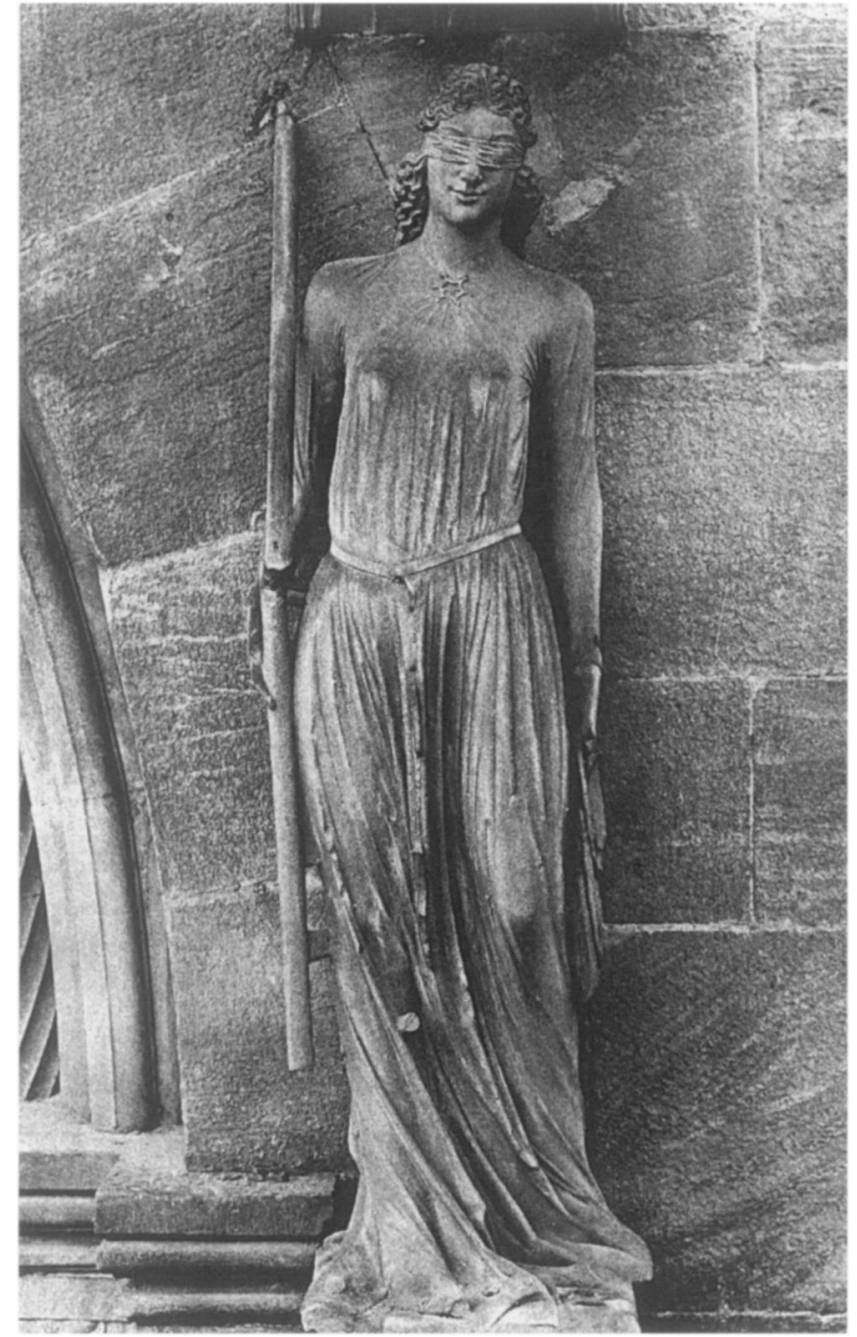

FIGURE 9. Synagoga, Fürstenportal (formerly), Bamberg Cathedral (photo: Foto Marburg / Art Resource, NY).

of Austria because the bishop had led a campaign against his own kinsman (Duke Frederick II the Quarrelsome) who had shirked imperial authority. ${ }^{50}$ Bishop Ekbert also orchestrated the marriage of Frederick's son Henry (VII) and then, when the rebellious Henry was deposed in 1235, Ekbert, along with the bishop of Salzburg, was appointed to escort Henry over the Alps to Aquileia. ${ }^{51}$ Meanwhile, back in Bamberg, the chapter under the leadership of Provost Poppo from the mid-1220s oversaw the cathedral's completion in time for its consecration on the 225th anniversary of the dedication of Henry II's original foundation. ${ }^{52}$

\section{Representing the Ideal}

Once the new Bamberg Cathedral was complete, the Fürstenportal served as the centerpiece in the performance of ecclesiastical power. ${ }^{53}$ The order of processions entering this

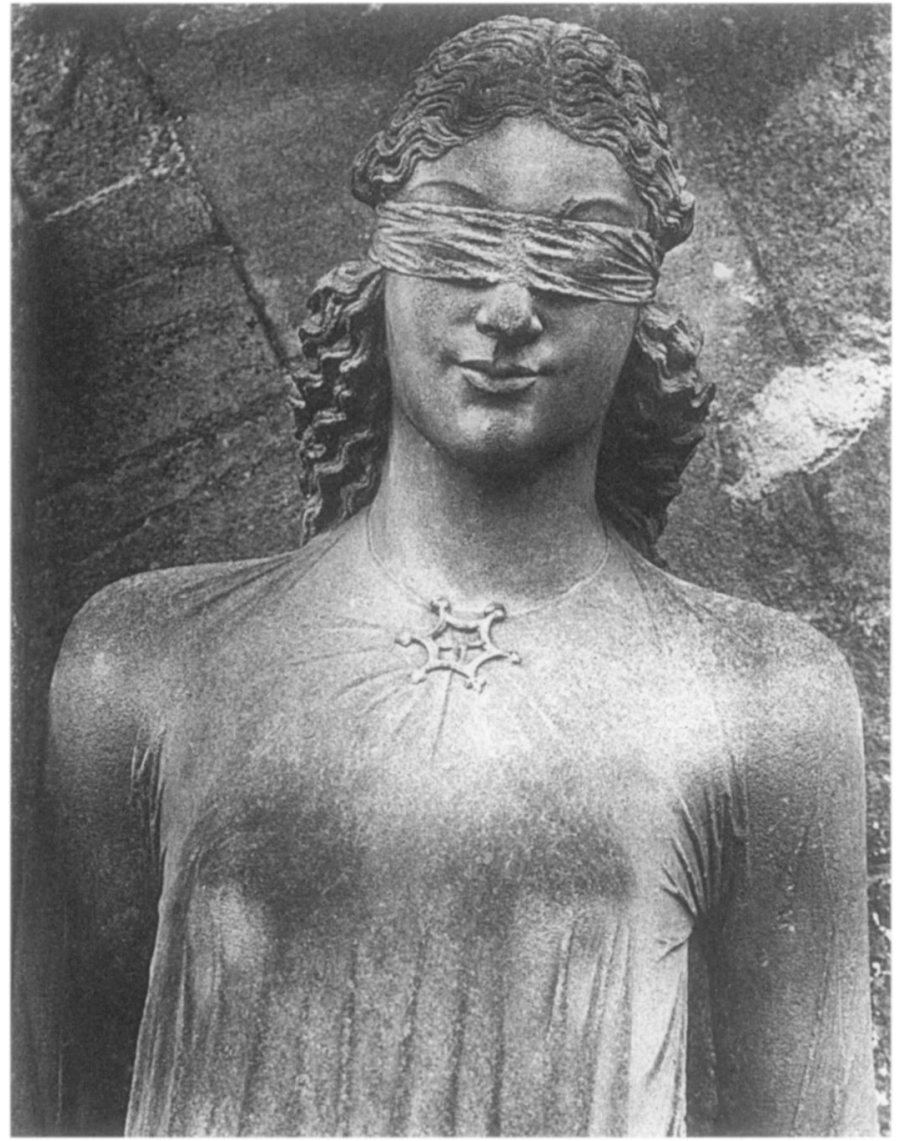

FIGURE 10. Bust of Synagoga, Bamberg Cathedral (photo: Foto Marburg / Art Resource, NY).

door presumably reflected cathedral hierarchy, beginning with the bishop, and provost, followed by twenty cathedral canons, fourteen canons-in-training (Kapitelsanwärter), multiple vicars, and students at the cathedral school (scholares), a group of which likely functioned as chanters (chorales). In addition, on many occasions leaders of Bamberg's three collegiate churches, Saint Stephen, Saint Gangolf, and Saint Jacob, participated in cathedral rituals. ${ }^{54}$ These were the ecclesiastical elites of the city who, along with special guests of the bishop, had access to the dynamic scopic experience shaped by the sculptures both outside and inside the Fürstenportal.

When the clerics of Bamberg looked up at the Fürstenportal, they encountered an ecclesiological visualization of three eras of human history: the age of the law, the age of grace, and the end of time foretold in Revelation. Synagoga represents the age of the old law (Figs. 9 and 10). She is a queen who once ruled the earth, but now her time has passed. Bearing a broken staff, she sways and drops her Mosaic tablets. Her blindfold marks her as misguided and unable to see the truth of Jesus' status as messiah. Ecclesia, in contrast, stands as steadfast ruler in the age of grace (Figs. 7 and 8). Her mantle and crown attest to the legitimacy of her rule while her chalice 


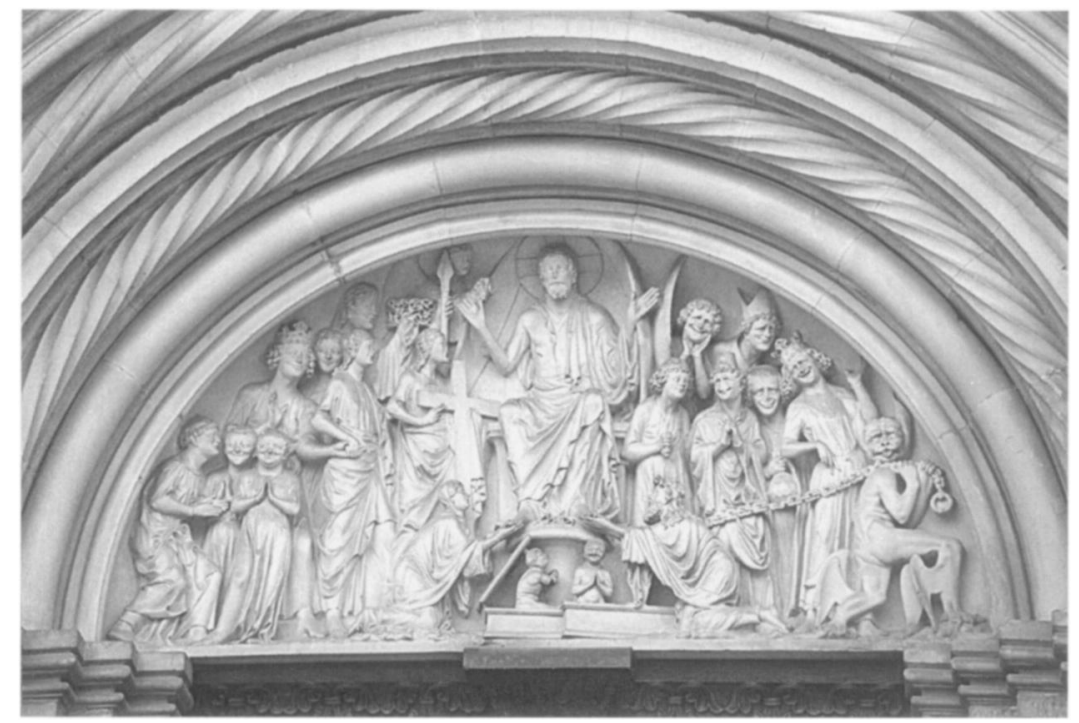

FIGURE 13. Last Judgment, tympanum, Fürstenportal, Bamberg Cathedral (photo: author).

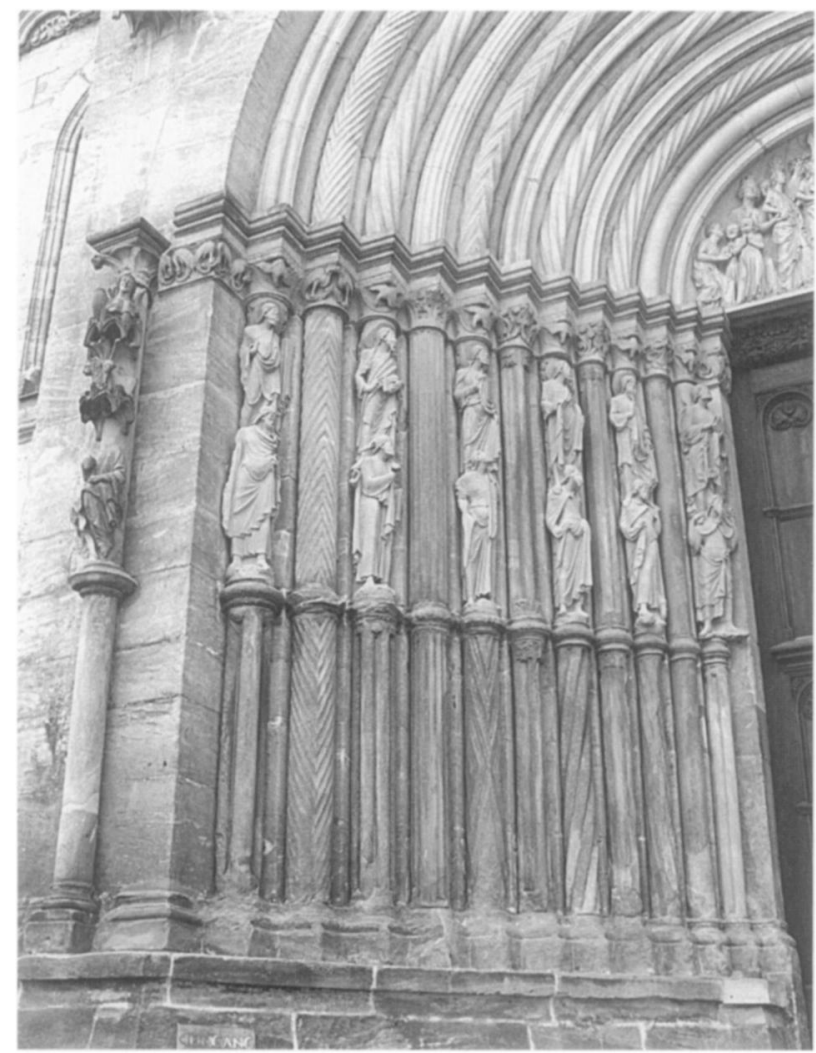

FIGURE 11. Apostles standing on the shoulders of prophets, left jambs, Fürstenportal, Bamberg Cathedral (photo: author).

and labarum (now destroyed) herald the sacraments and the Church's strength. ${ }^{55}$ The prophets and apostles of the jambs (Figs. 11 and 12), the former representing the age of the Old Testament, the latter the age of the New, are counterparts to

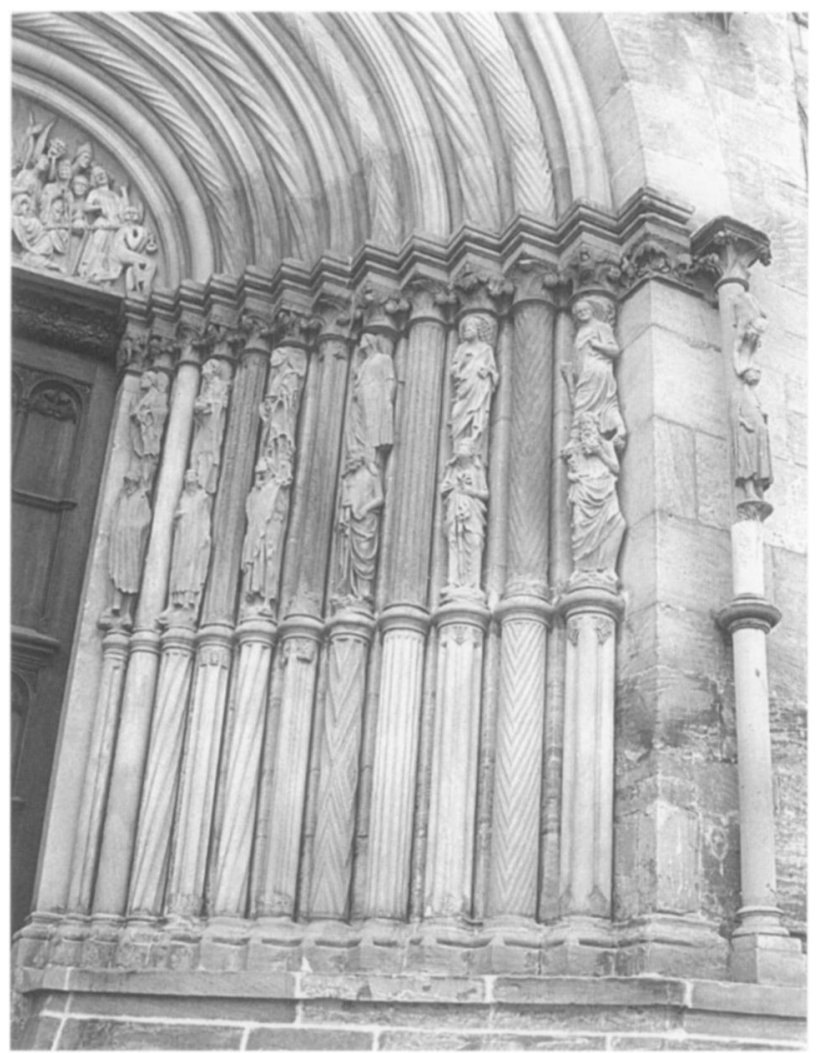

FIGURE 12. Apostles standing on the shoulders of prophets, right jambs, Fürstenportal, Bamberg Cathedral (photo: author).

Synagoga and Ecclesia. The Last Judgment scene in the tympanum (Fig. 13) visualizes the opening of the final era of history, when Christ will separate the saved from the damned, preparing the way for the descent of the Heavenly Jerusalem 
to earth. Off to the left, a trumpeting angel announces Christ's return, as Abraham rocks the souls of the saved (for overall view, see Fig. 3). The constellation of figures on the Fürstenportal diagrams the key tenets of the Christian notion of historical progression.

Visual qualities of the works drew the ensemble out of the realm of theology into the realms of politics and social life. When the "younger" workshop came to Bamberg, they created works in a new, dramatic, and lifelike style. ${ }^{56}$ Various factors contributed to the early-thirteenth-century experiments with naturalism, pioneered by workshops in northern Francea new emphasis on Christ's humanity following the Fourth Lateran Council, theological speculation on the status of the natural world, scientific inquiry into the physiology of vision and the theory of intromission, among others. Though it is impossible to know the reasons for the arrival of the "younger" team to Bamberg, as mentioned above, the archaeological and historical evidence suggests that Ekbert and his clerics invited the workshop to their city in the 1220 s. It is easy to imagine that the Bamberg magnates were aware of contemporary experiments with naturalism being worked out by sculptors in northern France and were eager to bring to their cathedral sculptors working in the most fashionable, innovative styles.

The techniques of the "younger" Bamberg workshop may have engendered different responses than some of the productions of the "older" team. ${ }^{57}$ For example, the blocky, hieratic figures of the Virgin and Child with saints on the Gnadenpforte seem to inhabit a remote realm when compared to the dramatic naturalism of Synagoga or the Bamberg Rider (compare Figs. 6,9 , and 14). In the sculptures by the "younger" workshop, bodies are anatomically coherent, gravity appears to pull on drapery, facial expression and gesture suggest human emotion. These stylistic qualities were amplified through coloration. New research by Walter Hartleitner suggests that the Fürstenportal tympanum scene was painted in a single pink tone. ${ }^{58}$ The Ecclesia and Synagoga figures, however, were vividly polychromed. Ecclesia's robe seems to have been ocher-colored, her crown was gold, and her hair was reddish brown. ${ }^{59}$ Synagoga's robe also likely was painted ocher, her blindfold black, and the clasp on her dress gold. The jamb sculptures may have been adorned with color, and the pupils of their eyes appear to have been painted black. ${ }^{60}$ The Bamberg Rider discussed more fully below was painted in similar tones.

Just as medieval theologians read scripture on multiple levels - the literal, the symbolic, the moral, and the anagogicso too medieval viewers recognized images on cathedrals to be polysemous. ${ }^{61}$ Thus it was possible for medieval monumental art to be understood by its original audiences as both conveying enduring tenets of dogma and inviting interpretation in relation to more immediate temporal concerns. I believe that at Bamberg and other early-thirteenth-century centers, dramatic and lifelike style combined with polychromy enhanced this phenomenon by visually referring to the corporeal world while at the same time projecting a transcendent ideal. The sculp-

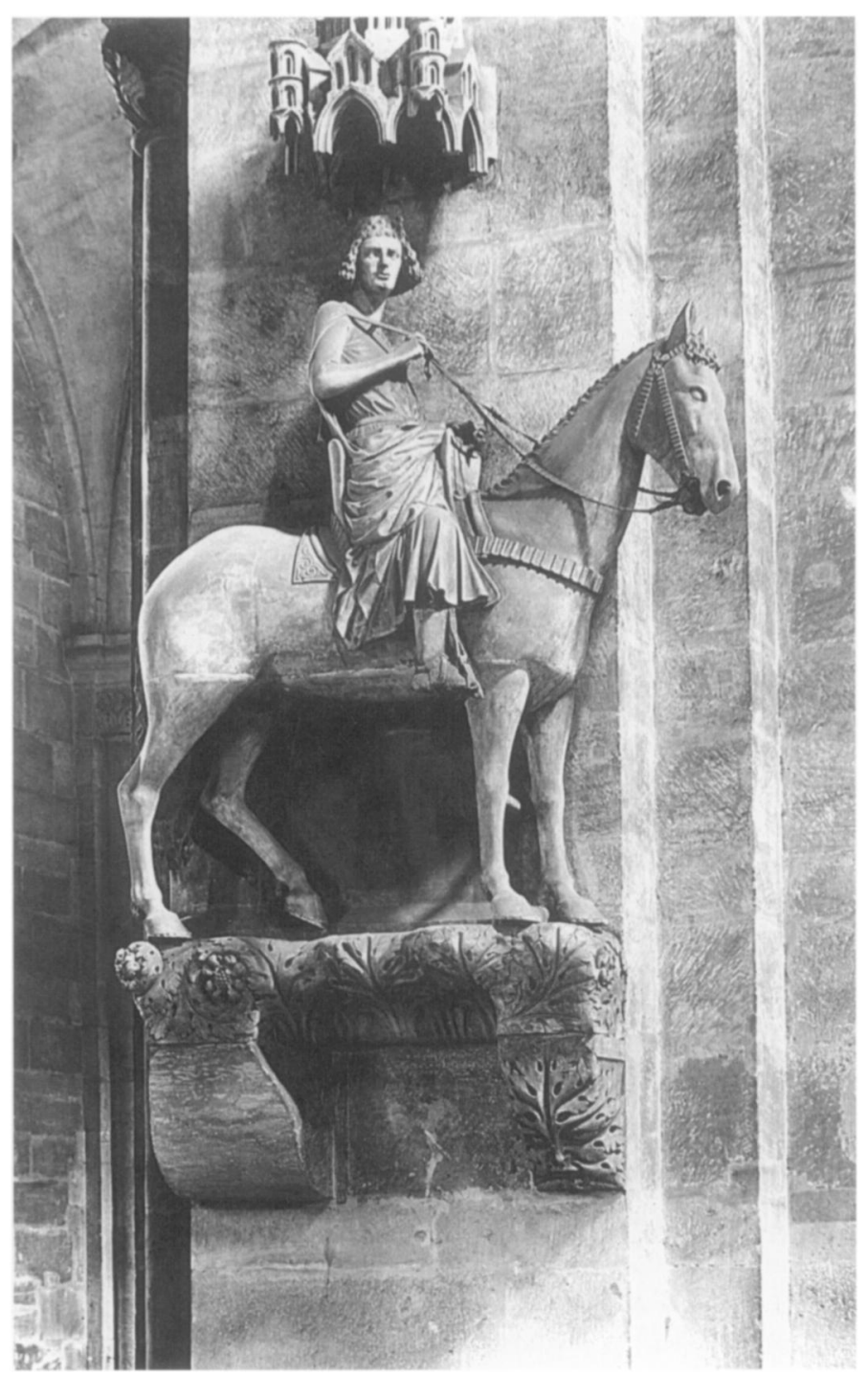

FIGURE 14. Bamberg Rider. Interior, east end of Bamberg Cathedral (photo: Foto Marburg / Art Resource, NY).

tures of Ecclesia and Synagoga at Bamberg in particular continued to convey their long-standing significances, acting as a pictorial manifestation of the ecclesiological notion of the harmony between the Old and New Testaments and the epochal shift that came with Christ's Incarnation and death. Made manifest in the forms and colors of the tangible world, these figures invited clerics to understand sculptural fabrications as embodiments of a divinely sanctioned reality. Recent scholarship recognizes that mimesis can draw attention to the artificial nature of images themselves and relies on a cooperative audience, invested in reading ideological projections as truths. ${ }^{62}$ The same can be said for the new style introduced at Bamberg as seen through the eyes of cathedral clerics. The relevant ideological projections at Bamberg orbited around ideals and realities concerning Jews. 


\section{Before the Law}

As the ecclesiastics of Bamberg proceeded toward the Fürstenportal, the figures of Ecclesia and Synagoga enframing a scene of judgment invited reflection on thirteenth-century imperial concerns about keeping earthly forces in balance. Medieval rulers were conceived of as vicars of Christ, minimizing disorder in the terrestrial realm so that it could as closely as possible mirror the celestial City of God, in the terms articulated by Augustine. ${ }^{63}$ In the twelfth and thirteenth centuries there was a new emphasis on the authority of the law within political theology. In his Policraticus (1159), for example, John of Salisbury deems the ruler an "Image of Justice," both a quasi-divine being who was above the law and a keeper of the laws that order society on a celestial model. ${ }^{64}$ Bishop Ekbert's ally Emperor Frederick II advanced such formulations, casting himself as law incarnate (lex animata) and instituting successive new legal codes with the intent to reform society and keep control over his vast realm, which included the kingdoms of Germany and Sicily as well as lands in northern Italy. ${ }^{65}$

Within these codes, Frederick's regulation of Jews manifested in microcosm his larger drive to bring divine order to the quotidian realm. In two legal proclamations instituted in the Sicilian kingdom, the emperor strove to keep both antiJewish violence and Jews themselves in check. In the Assizes of Messina (1221), Frederick stipulated that Jews bear an outward marker of their non-Christian status (probably a sky blue garment or patch), and Jewish men were to grow their beards. ${ }^{66}$ The aim of this ruling was to protect Christians from inadvertent sexual contact with "nonbelievers," as prescribed in the canons of the Fourth Lateran Council (1215). ${ }^{67}$ Later, in the Constitutions of Melfi, also known as the Liber augustalis (1231), Frederick reviled blasphemers, heretics, rapists, and murderers, but Jews were not included among the condemned groups. Moreover, here the emperor failed to reiterate earlier promulgations regarding distinctive dress for Jews. ${ }^{68}$ Indeed, the constitutions outlawed attacks based solely on religious grounds against Jews as well as Muslims. ${ }^{69}$ The evidence of this legal code, other imperial policies, and the presence of learned Jews at Frederick II's court have led some scholars to categorize the emperor as unusually Jew-friendly, an enlightened liberal avant la lettre..$^{70}$ But recent reassessment makes plain that Frederick's policies on Jews were primarily informed by commercial and practical concerns. ${ }^{71}$ Chief among the latter was the drive to keep order across the expanse of the imperial realm.

Within the German kingdom, Frederick also proscribed anti-Jewish violence as a means of instituting peace. Waves of attacks on Jews erupted periodically throughout the twelfth and thirteenth centuries in the German territories. A series of massacres across the German kingdom from the winter of 1235 to the winter of 1236 is particularly well documented. In this year mobs attacked Jews at Wolfhagen (near Kassel),
Lauda and Tauberbischofsheim (both in Baden), and at Fulda (in Hessen). ${ }^{72}$ Circumstances seem to have been similar at all these sites, though we have the most vivid account of the episode at Fulda, where the charred bodies of a miller and his five sons were discovered in an incinerated mill outside town. ${ }^{73}$ In this infamous instance of the blood libel, locals accused their Jewish neighbors of murder and arson and launched a riot during which thirty-four Jews were slaughtered. One account reports that, under torture, some Jews admitted to killing the Christian boys in order to draw blood for ritual use.

The violence of the mid-1230s came to a halt when the emperor intervened. Following the attacks in Fulda, after both Jewish and Christian plaintiffs had come before the emperor at the imperial residence at Hagenau in Alsace, Frederick II launched an investigation into the accusations against the Fulda Jews ${ }^{74}$ Once he found the charges to be false, the emperor instituted his Privilege and Judgment in Favor of the Jews (Privilegium et sententia in favorem Iudaeorum) of 1236 to protect Jews against further accusations and assaults. ${ }^{75}$ The ruling denounced and outlawed the blood libel and attacks against Jewish body and property on the grounds of such false accusations.

But with protection came submission. By the time Frederick II came to the throne, it was customary for emperors to claim Jews to be their special property. His grandfather Frederick I Barbarossa had instituted one charter that proclaimed imperial authority in all matters pertaining to Jewish life and customs (1157) and in a second charter (1179) deemed Jews members of the imperial treasury (ad fiscum imperatoris pertinent), that is, special protectees but implicitly special property as well. ${ }^{76}$ Frederick II's 1236 privilege contained language enhancing the notion that the Jews of the empire were directly servile to the emperor and none other, calling Jews servi camere nostre (or Kammerknechte).$^{77}$ Scholars have debated the significance of the term servi within the context of this and other German charters concerning Jews. ${ }^{78}$ Some maintain that it suggests that Jews held the status of slaves. Others argue that Jews were considered "serfs" or "servants" of the royal chamber, though those terms themselves are vague. For the purposes of the present argument, the significance of this ruling is that, though Jews were not literal servants of any imperial court, conceptually Frederick's 1236 privilege underscored a notion long prevailing in theology-that in the Christian world order, Jews were inferior beings to be kept under Christian watch. ${ }^{79}$

From the time of the early Church, theologians had conceived of Jews as crippled by their rejection of Christ and enslaved within the Christian realm. ${ }^{80}$ Paul explained the story of the twins Jacob and Esau (Gen. 25:21-34) as an allegory of the relation of the Church to the elder Synagogue. Born first, Esau held the family birthright but, scorning his divinely granted preeminence, sold this right to his brother. For Paul, prophecy put forth in Genesis was fulfilled in the split of the 
Church from the Synagogue: "the elder shall serve the younger" (Rom. 9:12). Augustine and other church fathers elaborated on what they held to be divine endorsement of Jewish submission: just as later in the Genesis tale Jacob gains his father's blessing and Esau is made to serve, so too is Christ "lord over his brethren, since his people have dominion over the Jews." 81 Theologians of the high Middle Ages continued to propagate the notion of Jewish servitude and went further to maintain that such submission of God's original "chosen" was now part of the Lord's plan. With his promulgation of 1236, Frederick II exploited a patently theological conception to justify a policy aimed at keeping the Jews of the German kingdom protected but also servile.

Scholars of history and religion have shown that conceptualizations debasing, yet protecting, Jews and Judaism were crucial to Christian articulations of political and spiritual authority in the twelfth and thirteenth centuries. In his landmark studies, R. I. Moore demonstrates how European secular and ecclesiastical rulers in this period sought to establish hegemony by identifying and constraining those deemed alien to the Christian community, particularly targeting Jews. ${ }^{82}$ But while Jews were condemned for blindly rejecting Jesus' status as messiah and for orchestrating his murder, theologians defended the persistence of Jews within Christian society. Pauline pronouncements, further developed by Augustine, insisted on the preservation of Jews: Jews were the Lord's original "chosen," as such they attested to the validity of the Old Testament and further, at the end of time (so went the hope) they would be converted to Christianity. ${ }^{83}$ In the high medieval drive to consolidate temporal and sacred authority, Jews were a conveniently built-in population of "outsiders," a community and a tradition against which Christianity could be defined. Frederick II's policy typified official attitudes toward and uses of Jews in the thirteenth century. The population was defended and thus preserved, yet kept in its place.

Up on the Bamberg Cathedral facade, a comely personification of Jewish history and religion appeared bound and weakened-included within the sacred order, yet impotent within it. From the plaza to the north of the cathedral, Bamberg's ecclesiastical retinue would have looked up and encountered the entirety of the Fürstenportal exterior. From this vantage point, Ecclesia and Synagoga, each slightly overlifesize ( $1.88 \mathrm{~m}$ including base), dwarf the other figures around the portal and originally would have commanded attention through their vivid polychromy. ${ }^{84}$ As the episcopal procession moved closer and as its members viewed the sculptures headon, Church and Synagogue offered a striking visualization of the opposition between physical strength and weakness. Ecclesia, ensconced in the fabric of her mantle, with crown firmly on her head, gazes outward, forthrightly. Originally bearing a chalice and battle standard, Ecclesia invites onlookers to join the community of the saved, assuring them that she has the strength to protect her flock. Synagoga hardly presents a formidable alternative. Her legs restrained by the diaphanous drapery of her robe, she is a figure off balance, swaying and threatening to topple over. Synagoga carries a broken staff, and the tablets of the law that once lent her authority slip from her hand, sliding down her left leg, ready to crash to the ground. The tumbling plaques even appear to be an attenuated appendage, elongating Synagoga's limp left arm, hence amplifying her feebleness. Robbed of her crown and blindfolded, Synagoga can neither lead nor protect. But Synagoga is also aestheticized. ${ }^{85}$ She embodies the ideals for female beauty codified in representations of the Virgin, female saints, and even Ecclesia. Synagoga's beauty marks her as consummate insider within the Christian world order projected on the cathedral facade. This use of the female form stands in counterdistinction to contemporaneous images of male Jews, such as those elsewhere at Bamberg Cathedral and in contemporary manuscripts (discussed below). A feminized, aestheticized figuration of Jewish history projects an ideal of Jewish inclusion against a reality of Jewish debasement. Like the Jews of the empire, Synagoga is a constitutive member of a divinely ordered society. But also like her real-world Jewish counterparts, in the Christian understanding, Synagoga's inability to recognize Jesus as messiah marks her as feeble dependent.

As the Bamberg clerics moved toward the portal, the Last Judgment tympanum came into view (see Fig. 13). At the central axis of the scene Christ sits enthroned as judge and Man of Sorrows. To Christ's right, the saved and heavenly attendants, in orderly rows, glide toward the savior. A cluster of angels bears the instruments of Christ's Passion, and one celestial agent takes a smiling monarch by the hand, leading him toward the Lord: the king who rules the earth following Christ's precepts will enjoy his eternal reward. On Christ's left, the disorder of damnation is materialized. Bodies twist and gesticulate wildly. A satanic beast with the face of an animal and the body of a man grasps a bejeweled chain that ensnares the transgressors of divine law, a coterie that includes a king, an ecclesiastic, and a grinning man with a sack of money, suggesting the greed associated with usury. ${ }^{86}$ Beneath Christ's feet are two supplicant figures of the Virgin and John the Baptist. The Bamberg clerics turned their heads to look up at the tympanum in a manner similar to the representations of prophets and apostles wedged into the portal jambs, though some of these sculpted figures turn away from the scene of judgment and thus engaged their clerical viewers head-on (see Figs. 11, 12, and 15). Old Testament seers, the first Christian acolytes, and contemporary ecclesiastical authorities alike all participated in an intervisual play, looking up at the spectacle of deific adjudication and looking out at one another. Clerics became witnesses to and participants within sacred history, as the scene of divine justice in the Fürstenportal tympanum invited meditation on the current temporal order. Emperor Frederick II's supporters hailed him as lex animata, the ruler who embodies and brings to earth divine order, the ruler who judges with divine approbation. Those who abide 


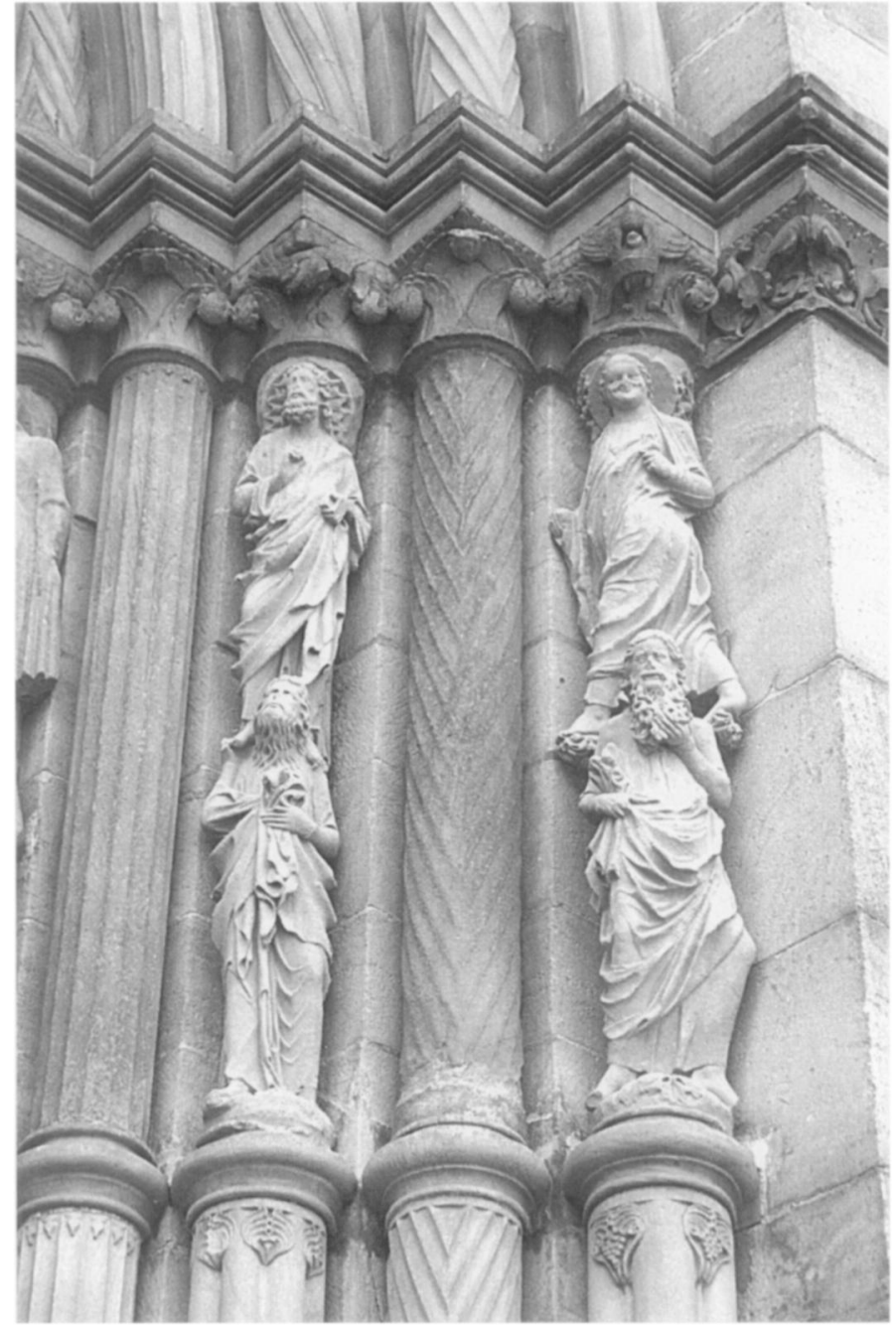

FIGURE 15. Apostles and prophets looking up and out, right jambs of Fürstenportal, Bamberg Cathedral (photo: author).

by Frederick's laws participate in the maintenance of earthly harmony. They will enjoy the rewards of the saved. Those who transgress his laws, who threaten the peace by spreading calumny and igniting riots, will forever be enchained by Satan.

Once the clerics of Bamberg reached the threshold of the cathedral, further images cued them to reflect on the position of Jews within sacred and civil society. To the right of the Fürstenportal, on the pillar beneath Synagoga, is the figure of a Devil blinding a Jew, identified by standardized iconography - beard and pointed hat (Figs. 16 and 17). ${ }^{87}$ Scholars have observed that this figure, more directly than Synagoga, refers to actual living Jewish populations. ${ }^{88}$ And Bamberg's population of Jews resided close at hand, concentrated in a street at the foot of the cathedral hill in the southern portion of the urban center (Figs. 4 and 18). ${ }^{89}$ Jews had been in Bamberg at least since the final years of the eleventh century. ${ }^{90}$ At this time Pope Clement III wrote to the Bamberg bishop telling him

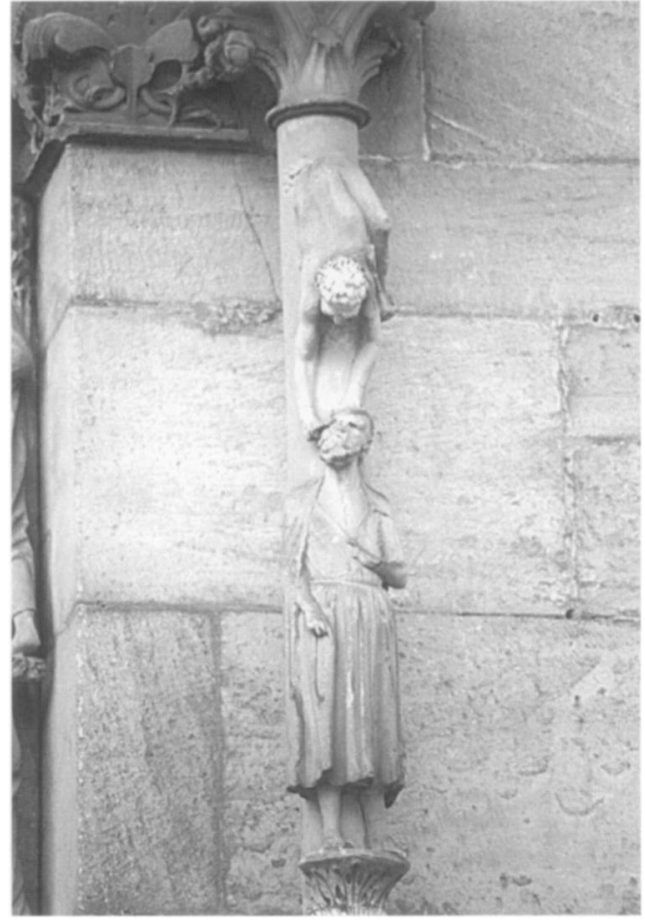

FIGURE 16. Devil blinding a Jew (column beneath Synagoga, Fürstenportal, Bamberg Cathedral) (photo: author).

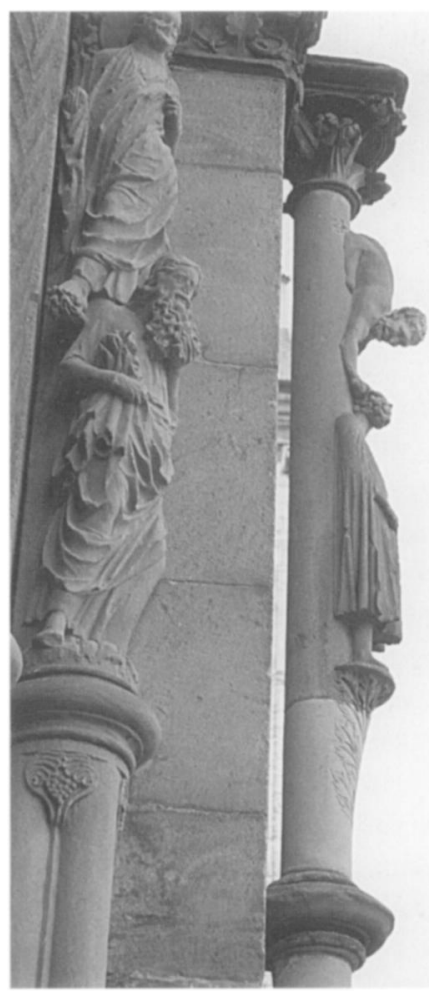

FIGURE 17. Devil blinding a Jew (column beneath Synagoga, Fürstenportal, Bamberg Cathedral). Photo taken from steps of Fürstenportal (photo: author). 
to be on the lookout for Jews who had converted to Christianity but were lapsing into their old traditions. ${ }^{91}$ A Jewish population in the city is also attested by Benjamin of Tudela's late-twelfth-century account (1160-1173), ${ }^{92}$ and the less reliable Miracula Cunegundis (1199-1200) tells of a Jewish conversion before the relics of Empress Kunigunde. ${ }^{93}$ In the early thirteenth century the Jewish street appears to have accommodated a synagogue, a school, and perhaps a bathhouse and a dance hall. ${ }^{94}$ In the same era a local rabbi, Samuel ben Baruch, was considered an authority on questions of Halacha and rituals, and he corresponded with rabbis throughout the German kingdom. ${ }^{95}$ In accordance with trends across northern Europe, the Jews of Bamberg seem to have been immersed in the money trades-pawn-broking and money lending. Documents particularly attest to financial deals between Bamberg ecclesiastics and local Jews, a circumstance that would periodically have brought members of the community up the cathedral hill. ${ }^{96}$

The bishop of Bamberg was obliged to see that the local Jewish population did not disrupt the civic order. For, as was the case across the German kingdom, the bishop of Bamberg also was the count of the region. It was his right to levy tolls and taxes on local trade and his charge to keep city life harmonious, which he did with the help of an episcopally appointed mayor (Schulthei $\beta$ ).$^{97}$ Frederick II's Privilege and Judgment in Favor of the Jews claimed authority over the Jews of the German kingdom, but the emperor seems to have exercised no imperial prerogative over Bamberg's community. So while in many Rhineland cities, Jews were made to pay heavy taxes to the imperial coffers, in Bamberg all such protection payments presumably went to the bishop. ${ }^{98}$ In exchange for such taxes, it was the bishop's obligation to defend the community, keeping anti-Jewish violence to a minimum by closely regulating Jewish-Christian social interaction.

In this task, Ekbert and his successor Poppo had a blueprint to follow. In 1215, like most authorities in Latin Christendom, Ekbert traveled to Rome for Innocent III's Fourth Lateran Council. At this congress, among many other rulings, the pope and his lawyers issued decrees aimed at limiting Jewish-Christian contact and curtailing Jewish authority over Christians, mostly in the context of the money trades. ${ }^{99}$ One canon sought to ensure that Christians would not be exploited by Jewish moneylenders and thus would not be financially beholden to Jews. ${ }^{100}$ Another ruled that Jews were forbidden to hold public offices. ${ }^{101}$ The canon that most affected the daily lives of Jewish and Christian city dwellers alike was the one that had influenced Frederick II's Assizes of Messina, which required Jews to distinguish themselves visibly from Christians so as to avoid sexual contact or even marriage between members of the two faiths. ${ }^{102}$ It was up to the Bamberg bishop and his officers to enforce such ordinances locally. ${ }^{103}$ It seems Bishops Ekbert and Poppo did a fair job of keeping the peace in their domain. During their reigns only one case of local antiJewish violence was recorded: in 1218 two young Jewish men,

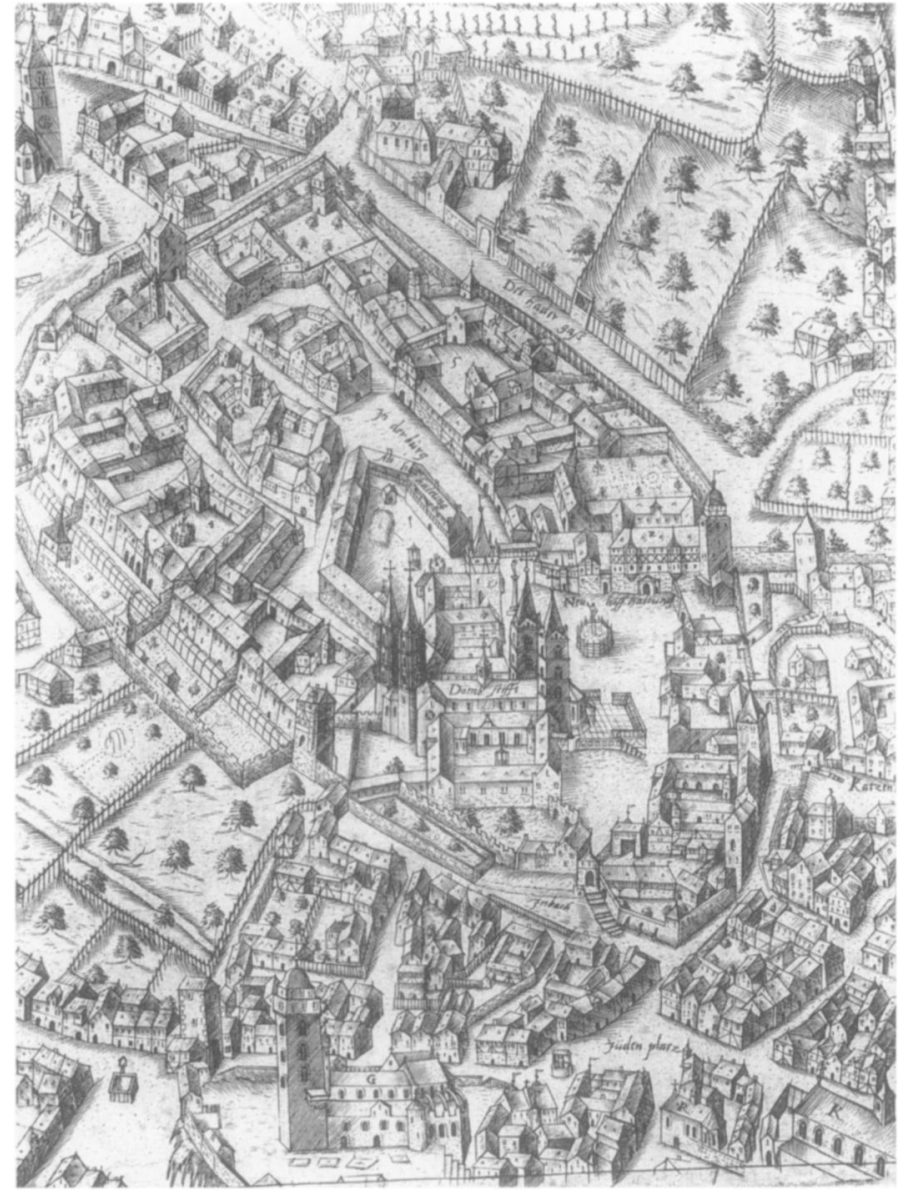

FIGURE 18. View of Bamberg's cathedral hill and valley below; Jewish quarter at lower right. Etching from 1602 (Staatsbibliothek, Bamberg, V. B. 22) (photo: Foto Marburg / Art Resource, NY).

perhaps traders from Ahar (in northwest Iran), were for unknown reasons killed in Bamberg. ${ }^{104}$ Under Bishop Ekbert and Bishop Poppo, Jews became absorbed physically and conceptually within the episcopally ordered city of Bamberg in a local manifestation of the prescriptions of papal ordinances and of Frederick II's kingdom-wide juridical ideal.

As the clerics of Bamberg stood at the top steps of the Fürstenportal, they encountered a figure of a Jew, victimized by the Devil. This Jew bears the trappings of earthly success, wearing a long tunic and mantle, as well as the pointed hat and beard identifying him unequivocally. Though he has achieved worldly riches, he is spiritually bankrupt because he has allowed himself to fall victim to devilish forces that blind him from the truth offered by the Church. ${ }^{105}$ In his wealth, he echoes the figure of the usurer, clutching a coin purse on the side of the damned in the Fürstenportal tympanum. He thus also functioned as a moralizing figure, a Dives type, personifying Vice. He was an earthly admonishment preparing viewers for the ultimate judgment visualized above. ${ }^{106}$ Moreover, the Jew 


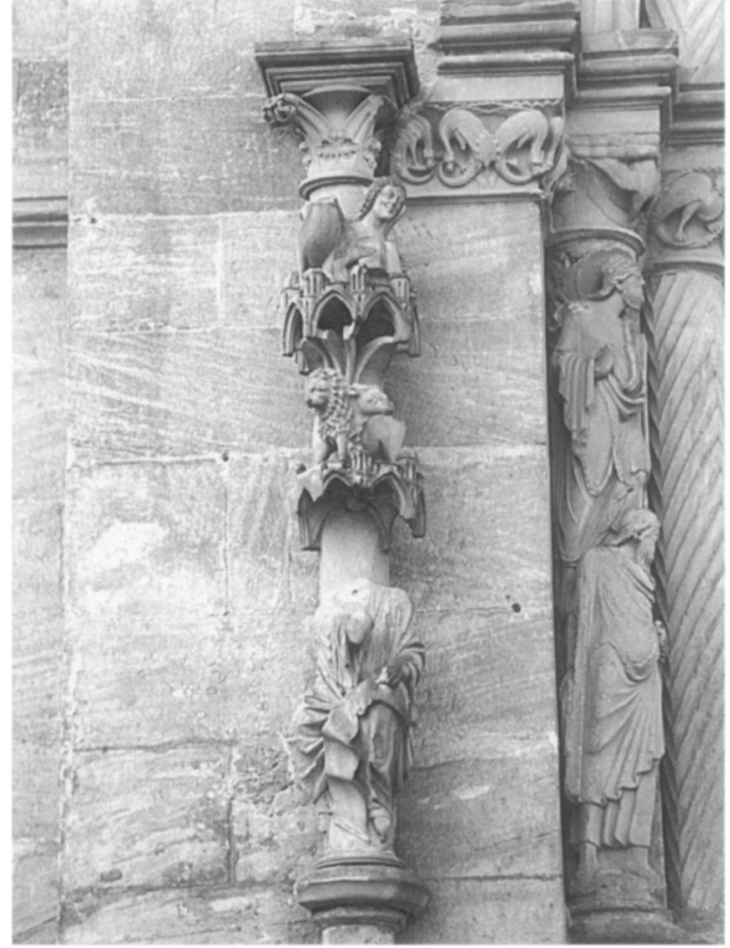

FIGURE 19. Seated figure and symbols of the evangelists (column beneath Ecclesia, Fürstenportal, Bamberg Cathedral) (photo: author).

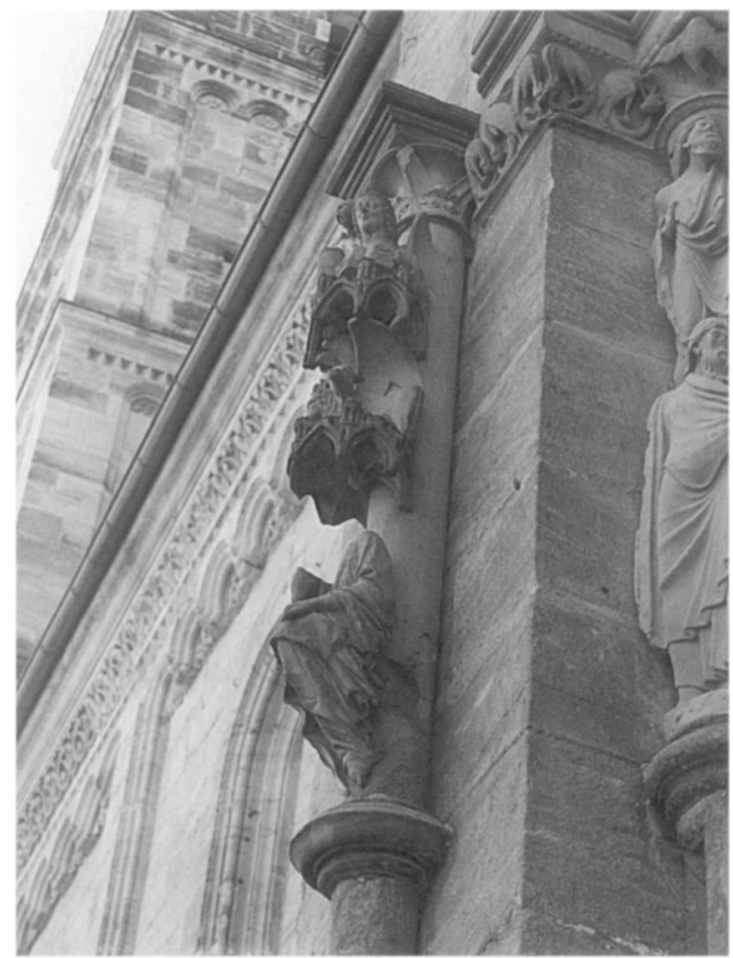

FIGURE 20. Seated figure and symbols of evangelists (column beneath Ecclesia, Fürstenportal, Bamberg Cathedral). Photo taken from steps of Fürstenportal (photo: author). fingers the cord of his mantle, a gesture associated with aristocratic bearing. The same pose is seen in contemporary depictions of regal or noble figures at centers across northern France and Germany, including the figure of the Bamberg Rider himself. ${ }^{107}$ In this context, the gesture only underscores the folly of the Jew who is seduced by the outward markers of status but has none of the inner nobility to resist Satan. The bivalent nature of the Jew came to the fore as the Bamberg clerics compared the figures on the pillar beneath Synagoga to those on the pillar beneath Ecclesia. On Ecclesia's pillar sits a now headless figure, apparently an Old Testament prophet or king, while above this figure are the symbols of the evangelists representing the Gospels (Figs. 19 and 20). An Old Testament figure placed below the evangelist portraits alludes to Judaism's status as the foundation, the prehistory of the Church. Thus the figures on Ecclesia's pillar serve as a validation of the faith, though they also attest to Judaism's obsolesence. An insistence on Christian dominance over Jewish forebears is further articulated in the Fürstenportal jambs, where apostles find their footing on the shoulders of prophets. The stalwart Ecclesia paired with the languid Synagoga, in their turn, present this same notion in an alternative visual form. Integrated within the larger ensemble of the Fürstenportal, Ecclesia and Synagoga invited the clerics of Bamberg to meditate on the position of Jews in the Christian realm in general and within their city in particular. The Bamberg bishop lorded over a civic space in which a Jewish population, both protected and restrained physically and socially, was integrated within the fabric of the city. So too up on the cathedral facade, Synagoga, included but incapacitated physically, was integrated within a fabricated conception of historical progress.

\section{Triumphal Entry}

As the episcopal retinue moved through the Fürstenportal, the Church's dominance over her forerunner became all the more visually emphatic. Ecclesia's heavy robe encircles her body so that waist, torso, and posterior are subsumed in a swath of fabric (Fig. 21). She is a material manifestation of coherence and strength. From the Fürstenportal threshold the clerics could see that Ecclesia's back is a solid block of stone, a columnlike monolith (Fig. 22). Seen while approaching the cathedral entrance, the figure of Synagoga, on the other hand, disintegrated. From the entryway steps, her form became the very embodiment of lassitude (Fig. 23). Her legs are restrained by twisted drapery, her head hangs off to the side, and she teeters, ready to topple from her pedestal like the fallen idols depicted in contemporary manuscripts. ${ }^{108}$ And seen from the top step, glancing up to the right, Synagoga appeared to crash in on herself (Fig. 24). Hip and splintered staff jut forward. Synagoga's useless weapon becomes an analog for her entire body; staff and figure alike are broken tools. Her bent arm and the lower part of her staff further create a dramatic zigzag pattern, and her body slouches so much that her head is hardly 


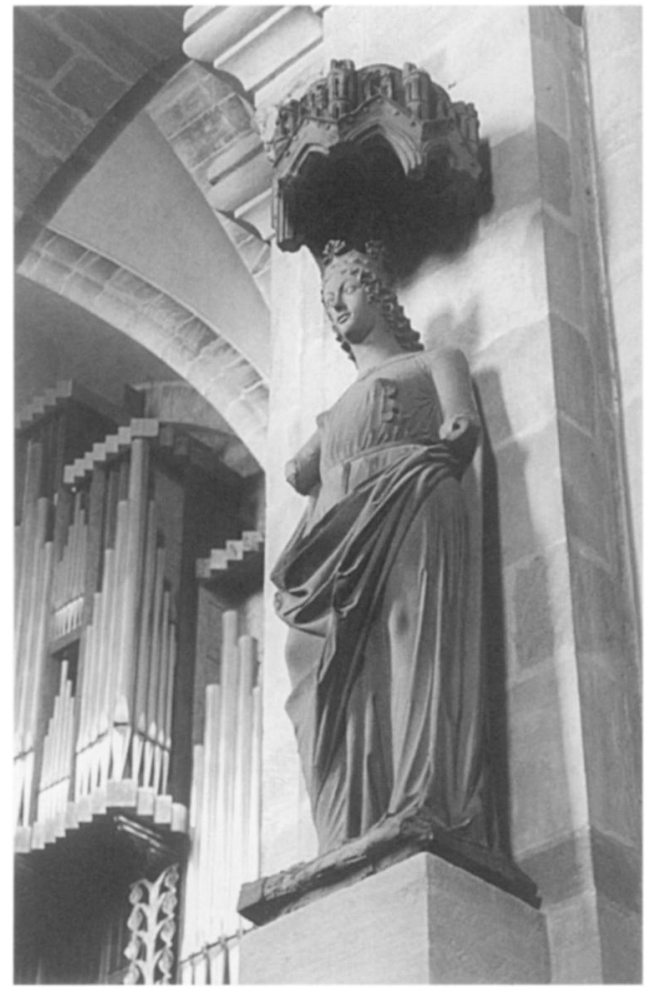

FIGURE 21. Ecclesia from the right, Bamberg Cathedral (photo: author).

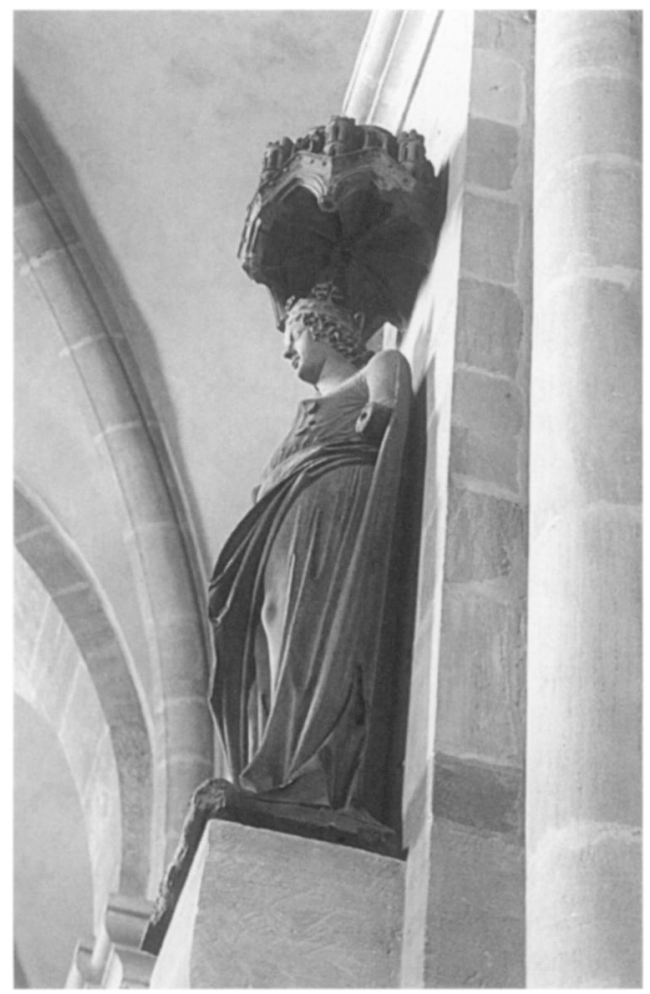

FIGURE 22. Ecclesia from the extreme right, Bamberg Cathedral (photo: author).

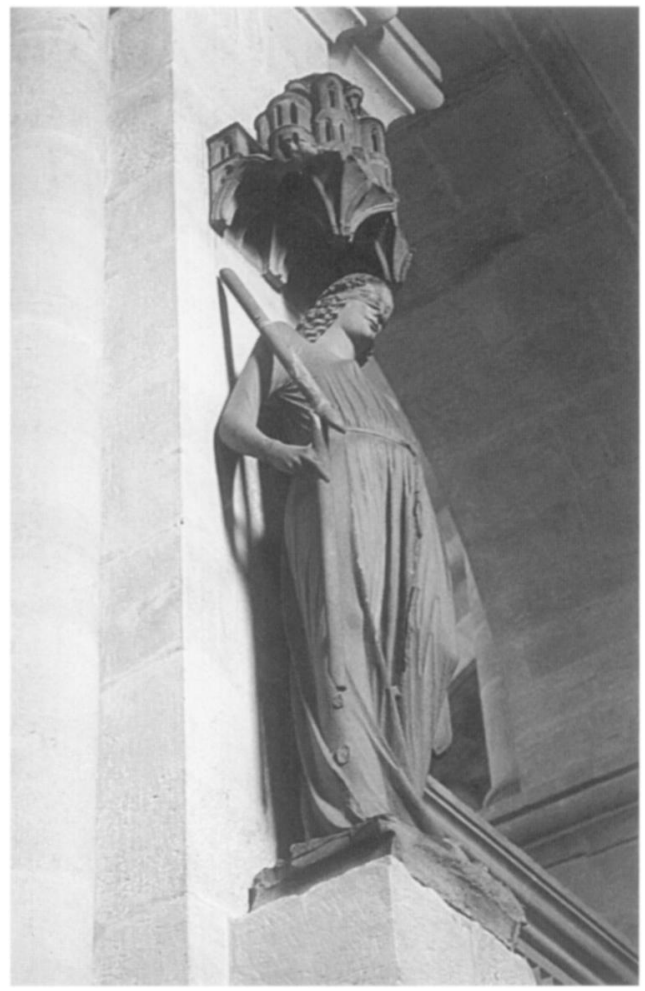

FIGURE 23. Synagoga from the left, Bamberg Cathedral (photo: author).

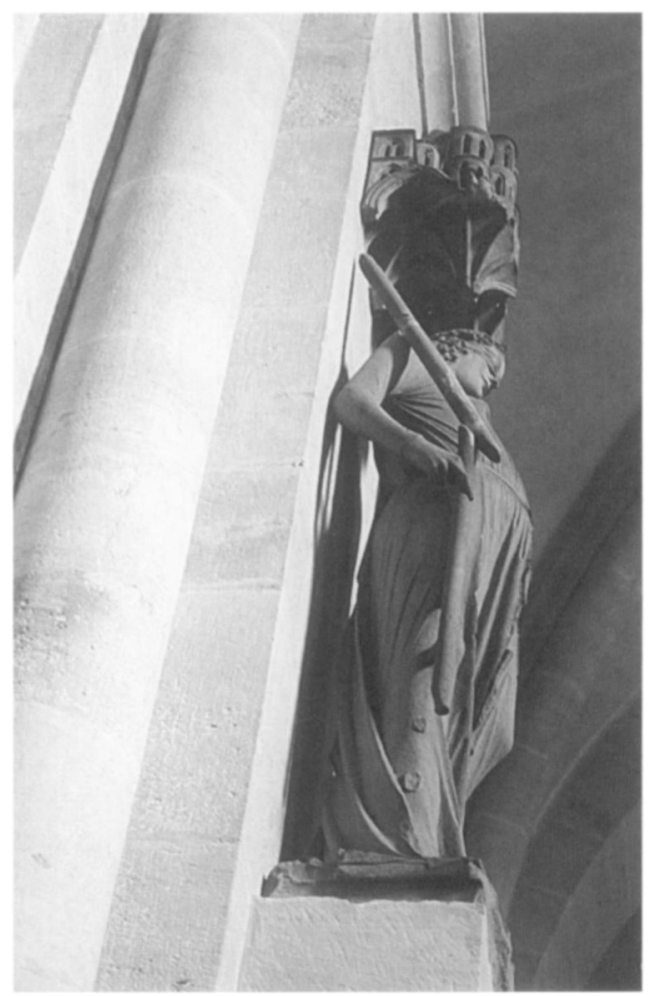

FIGURE 24. Synagoga from the extreme left, Bamberg Cathedral (photo: author). 


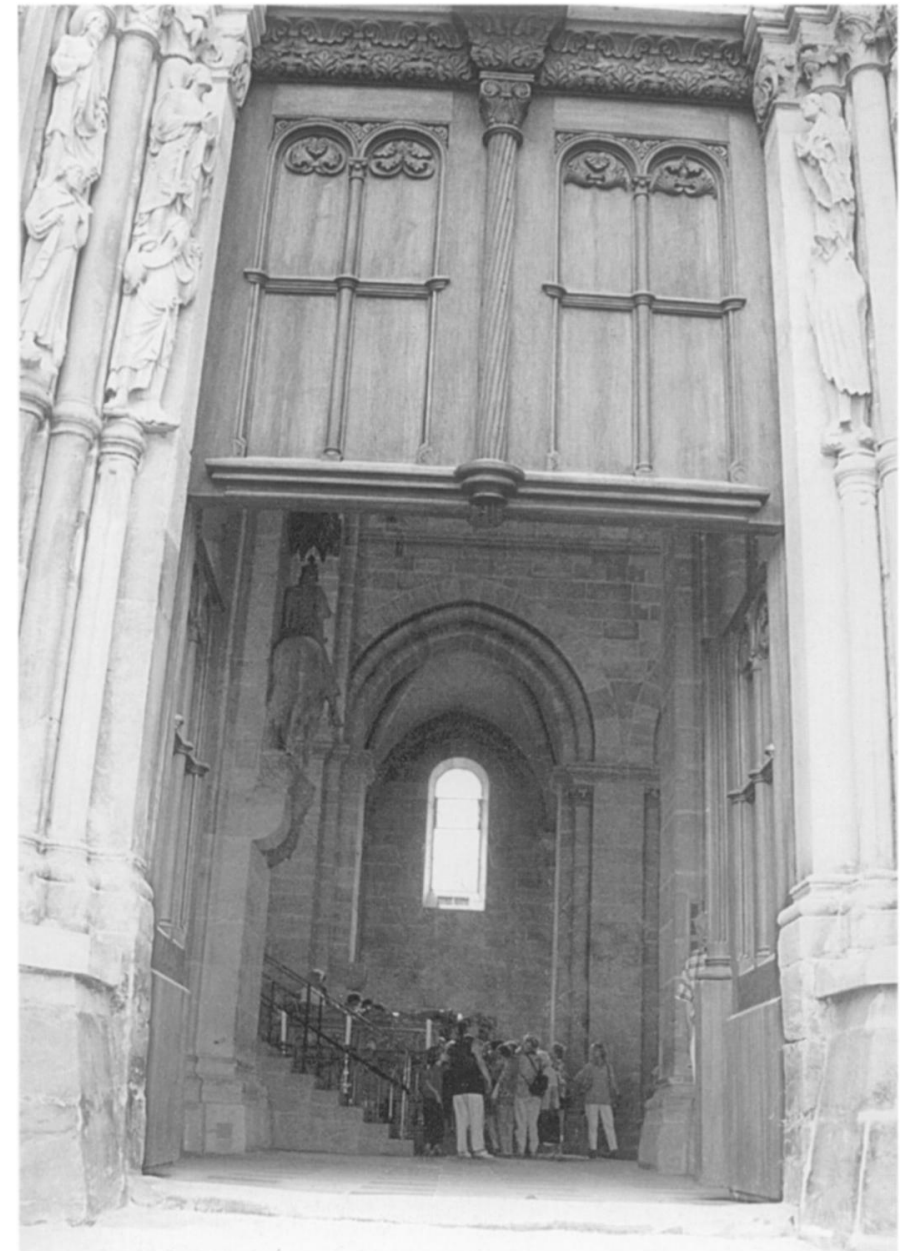

FIGURE 25. View through the Fürstenportal with the Bamberg Rider at left, Bamberg Cathedral (photo: author).

visible. Lifelike and dramatic style amplified a long-standing artistic motif. Through form and posture Ecclesia and Synagoga became the quintessence of Christian strength and Jewish decrepitude.

When the members of the cathedral hierarchy entered Bamberg Cathedral, they found themselves gazing up at the rear end of a horse and a mounted prince, that is, the back end of the Bamberg Rider (Figs. 25 and 26). ${ }^{109}$ The animate clerical retinue thus became attendants of this stony monarch, who led the bishop and his men to the interior of the church. Various feasts at Bamberg called for ritual processions, integrating the multiple altars that originally were set up throughout the building's nave and aisles. ${ }^{110}$ The cathedral's two principal altars, though, were in the east and west choirs. These were designated for the canons and the bishop respectively, though other dignitaries, as well as a group of canons, often joined the bishop at the west choir. ${ }^{111}$ So on many feast days, once the episcopal retinue entered the building through the Fürstenportal, they walked toward the cathedral's nave, moved beneath

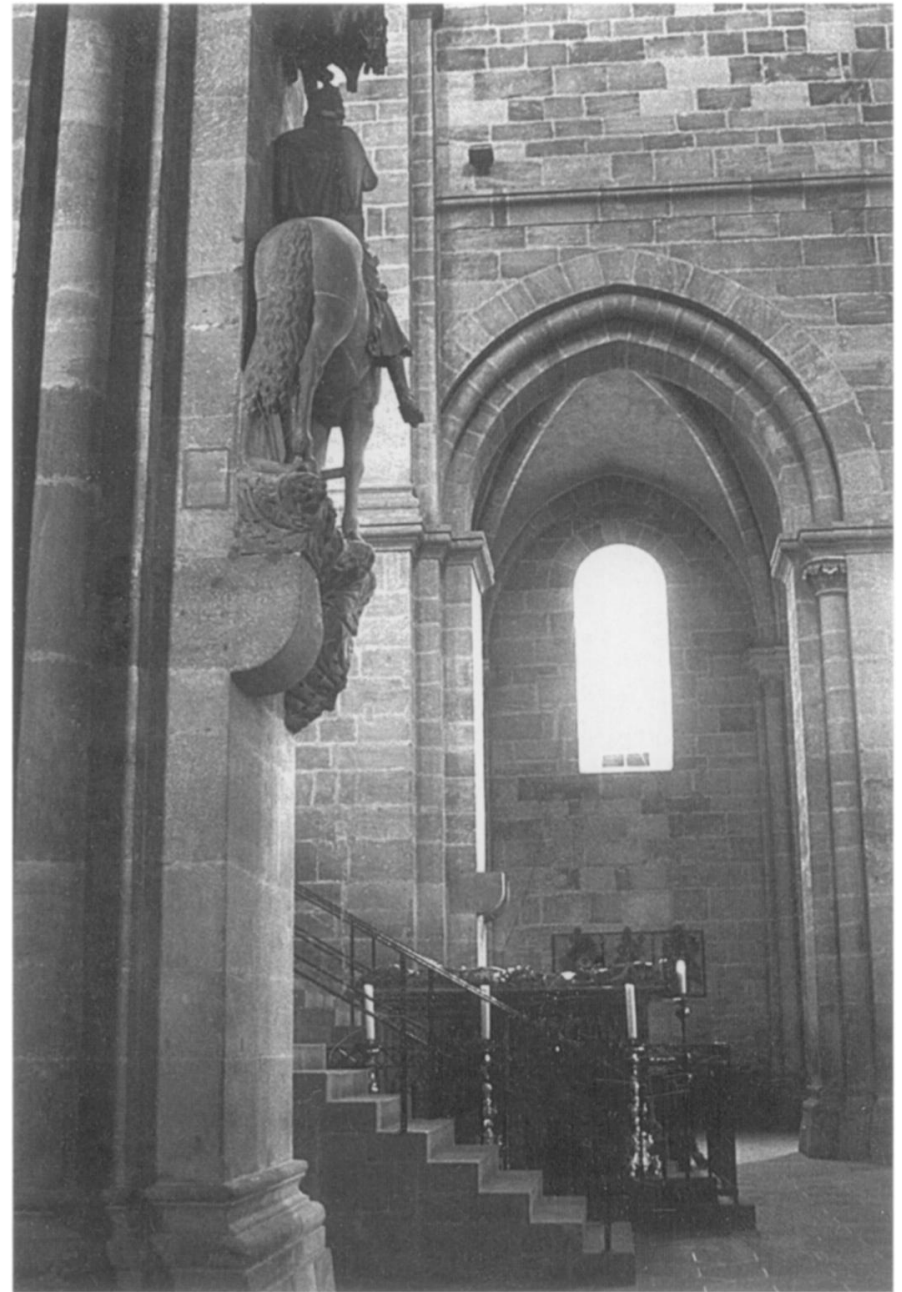

FIGURE 26. Bamberg Rider from the rear, Bamberg Cathedral (photo: author).

the Bamberg Rider, and then turned west toward the Peterschor, the episcopal choir (Fig. 28). ${ }^{112}$

Moving into the cathedral and looking up at the Rider, the procession of clerics encountered a model Christian prince, complete with all the features that artists across the empire and in the French kingdom had codified as markers of rulership (Fig. 27). The Rider's piercing eyes, smooth, beardless face, chin-length wavy hair, mantle, belt, and the brooch affixed to his collar recall the countenance and garments of sculpted kings on the eastern portions of Reims Cathedral and in the glass at Chartres, for example. ${ }^{113}$ The figure's grandeur originally would have been enhanced by polychromy in tones that complemented those painted on Ecclesia and Synagoga. The Rider had dark brown hair and black pupils and wore a yellow robe covered by a reddish orange mantle that seems to have been heightened with silver-colored foil. His crown, belt, and stirrups were gold, and his horse was painted white with gray spots. Gold leaf adorned the harness and bridle as well. ${ }^{114}$ 


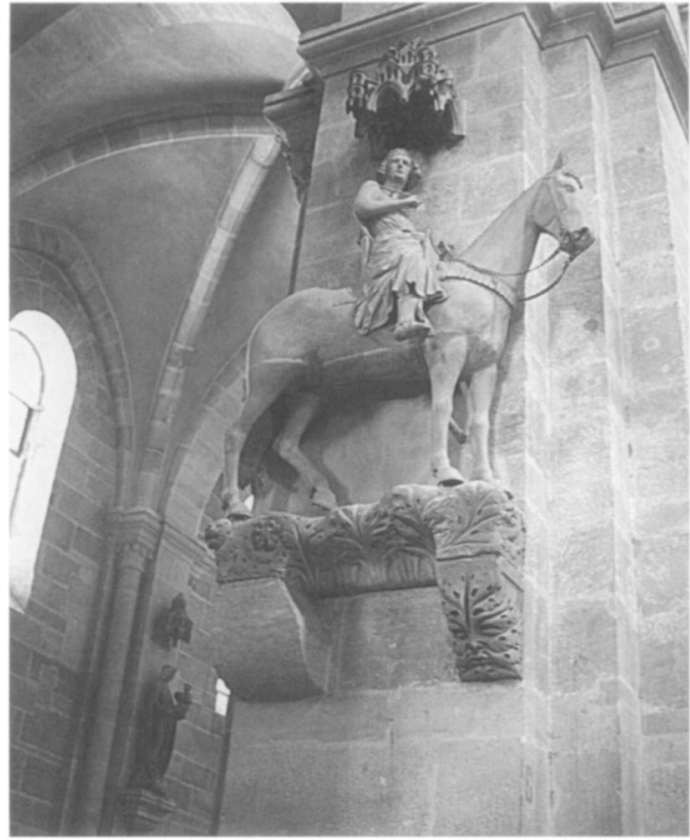

FIGURE 27. Bamberg Rider from below, Bamberg Cathedral (photo: author).

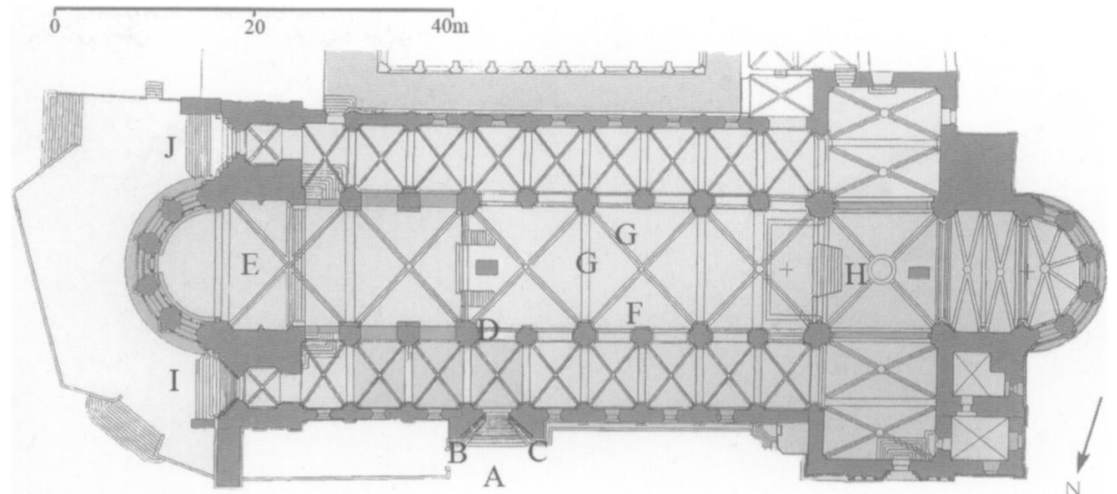

A. Fürstenportal

B. Ecclesia

C. Synagoga

D. Bamberg Rider

E. East choir (Georgenchor)

F. Nave

G. Locations of Jews in vaults

H. West choir (Peterschor)

I. Gnadenpforte

J. Adamspforte

FIGURE 28. Plan of Bamberg Cathedral (by the author with assistance from Wes Evard, 2006).
From the spot beneath this sculpted and painted king, members of the episcopal procession gazed out on the Rider's domain (Figs. 27-29). While all churches are conceived as earthly reflections of the Heavenly Jerusalem, at Bamberg we have unusually rich evidence of the now-lost polychrome and ornamentation that manifested this metaphor visually. ${ }^{115}$ At the time of its consecration, the walls and vaults of the Bamberg interior were a deep pink, the ribs and other architectural details were ivory white, the columns gray, the capitals and consoles yellow ocher, and in the high altar at the west end, a diaper pattern adorned the vaults and ribs (traces remain). Colored glass in the windows and multiple tiny oil lamps hanging from the ceiling amplified the painted splendor of the space. Following typical practice, the cathedral was further adorned on high feast days. The walls were hung with tapestries, the space was lit by ornamental lamps, and luxurious reliquaries were displayed. ${ }^{116}$

At the margins of this celestial vision, in the vaults of the nave, are two ghastly faces, painted on the ceiling apparently in the early thirteenth century (Figs. 30-32). ${ }^{17}$ They hover in the nave vaults, in the second bay from the west, one head in the southern quadrant, the other in the eastern quadrant, each adjacent to a vault rib. Visible to the clerical retinue both from the nave and from the western high choir, these heads mocked the celebrants below. Both wear a pointed cap with a large brim extending out over his face. One is oriented frontally, exposing fully his beastlike, half-closed, sleepy eyes and large nose with prodigious nostrils. From his gaping mouth emerges a dangling tongue, wagging like that of a dog. Two shaggy

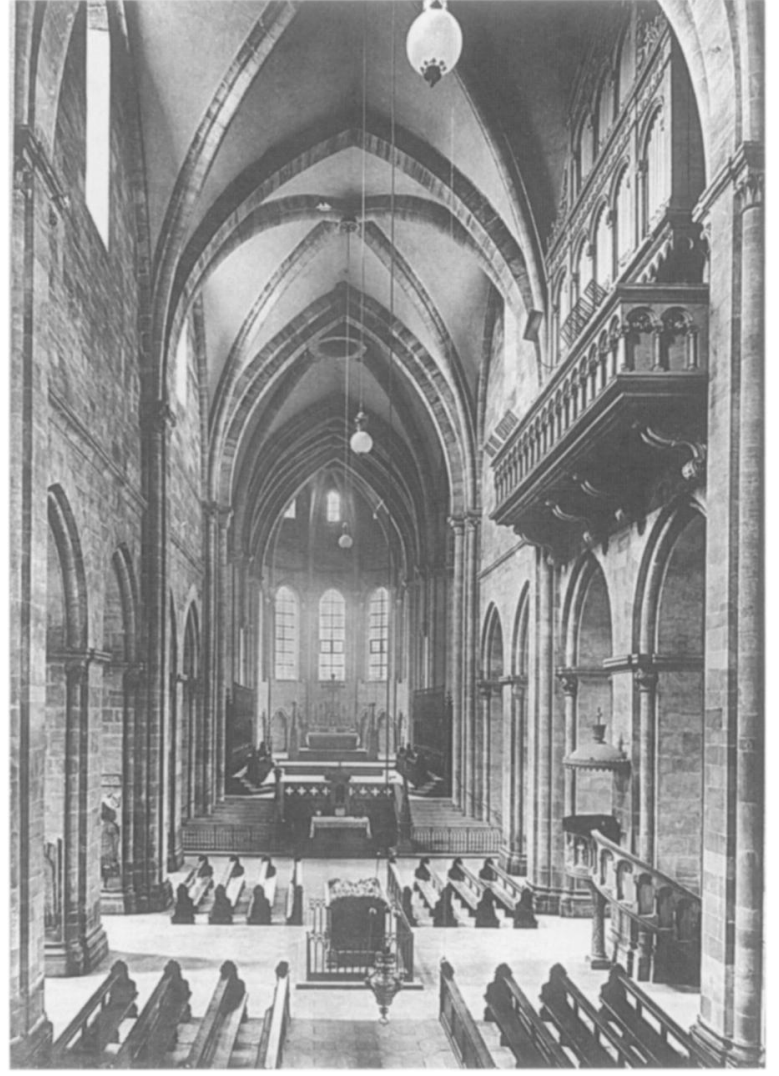

FIGURE 29. Nave and west choir, Bamberg Cathedral (photo: Foto Marburg / Art Resource, NY). 


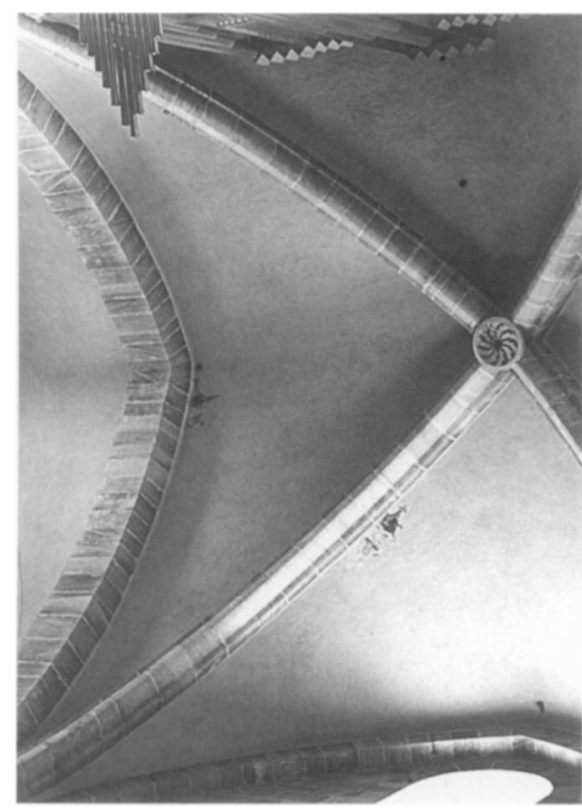

FIGURE 30. Jews painted in nave vaults as seen from west end of Bamberg Cathedral (photo: author).

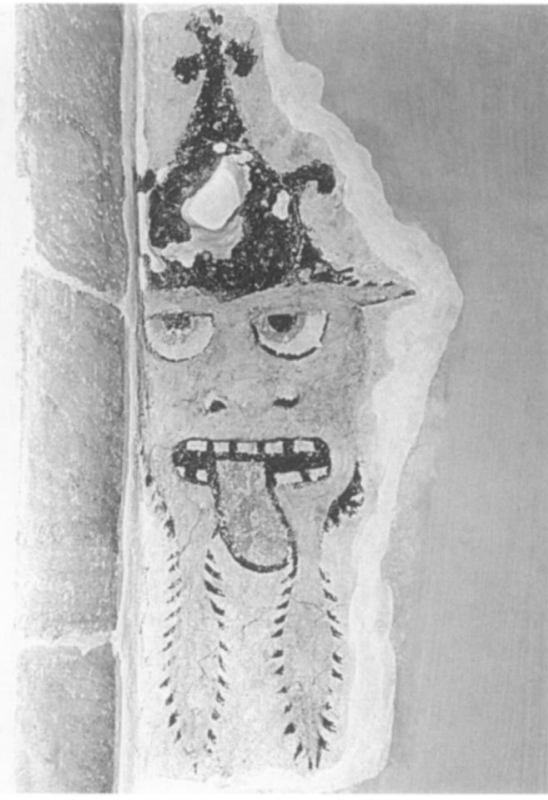

FIGURE 31. Jew in nave vault, Bamberg Cathedral (photo: Bayerisches Landesamt für Denkmalpflege).

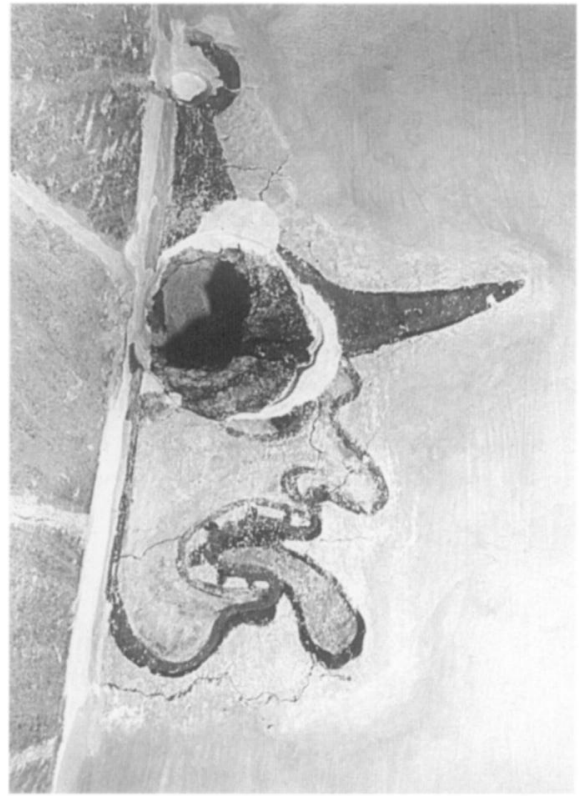

FIGURE 32. Jew in nave vault, Bamberg Cathedral (photo: Bayerisches Landesamt für Denkmalpflege). bits of beard hanging from his chin underscore the figure's patent brutishness. The other figure is in profile. Like his neighbor, he has bulging, somnolent eyes and an open maw with outstretched tongue. He also exhibits an excessively large nose whose form echoes those of his hat brim and tonguethree protruding members refusing to be contained. The pointed hats, beard, and oversized proboscises accord with stereotyped images of Jewish men seen in contemporary works created at centers across northern Europe (for example, Fig. 33). ${ }^{118}$ Mocking and nefarious Jews were poised at the margins of the celestial kingdom governed by the Bamberg Rider. They threatened the divine order, but were kept at bay.

Once the bishop and his clerics settled in the stalls at the western choir, they could look up at the Jewish figures in the vaults and contemplate the Bamberg Rider. The Rider casts his gaze toward the southwestern portion of the cathedral, thus back toward the high choir, the episcopal retinue, and perhaps a monumental crucifix once installed there along with a tomb for Pope Clement II (d. 1047). ${ }^{119}$ Who is this ruler overseeing the Bamberg interior? No attributes identify him explicitly as a historical or a sacred figure. ${ }^{120}$ Identifications have ranged from biblical heroes to saints to kings, and today many accept the argument that he is St. Stephen of Hungary, a celebrated saint at Bamberg. ${ }^{121}$ While some interpretive communities in the thirteenth century and later may have understood the Bamberg Rider to be a representation of the sainted Hungarian king and none other, I believe that the Rider was created to function in more general terms as a type for divinely sanctioned rule, rather than to depict a specific individual. As a type, he accommodated contemporary readings relevant to the explicitly temporal preoccupations of Bishop Ekbert, his successor Poppo, and their clerics, particularly the network of legal realities and ideals surrounding Emperor Frederick II. ${ }^{122}$ While the figure is not a portrait of the Staufen ruler, I am convinced that the Bamberg clerics intended the Rider to refer to both an eternal ideal and a contemporary reality. ${ }^{123}$

The common visual features and proximate installation of the Bamberg Rider with Ecclesia and Synagoga make these figures a coherent trio, the queenly figures on the Fürstenportal exterior functioning as pendants to the Rider sculpture within. ${ }^{124}$ These three sculptures are of equal scale, carved in a common style, and originally were similarly polychromed. As a group they echo other medieval representations of rulers accompanied by feminized figurations of power. The Magdeburg Rider ensemble, a work contemporary with Bamberg Cathedral, offers the most suggestive conceptual analogy (Fig. 34). ${ }^{125}$ The Magdeburg Rider is a freestanding, monumental mounted ruler accompanied by two female figures, one bearing a shield, the other a spear (apparently originally with a banner). The group was installed on a pedestal with a baldachin in the middle of the market square of Magdeburg in the 1230s. Virginia Roehrig Kaufmann argues that the equestrian figure refers to either the empire in the abstract or the person of Frederick II in particular and that the paired female personifications refer to the Italian and German components of the empire. ${ }^{126}$ Formal and stylistic similarities between the Magdeburg Rider and the Bamberg Rider as well as diplomatic contacts between Bamberg's Bishop Ekbert and Magde- 


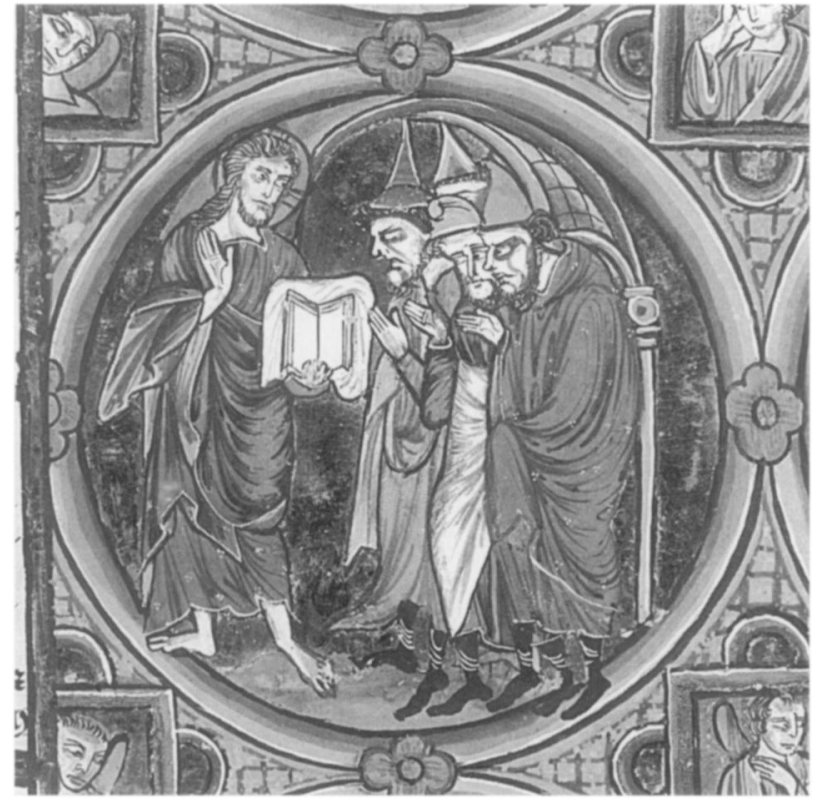

FIGURE 33. Jews mocking Christ and the Gospels, Bible moralisée, Vienna, Österreichische National Bibliothek, MS 2554, fol. 37 (roundel a) (photo: A. N. L. Picture Archives, Vienna).

burg's Archbishop Albrecht von Käferberg (1205-1232) have impelled scholars to discuss the two equestrian sculptures in relation to one another. ${ }^{127}$ Yet the structural similarities between the two groups - that is, the association of a mounted ruler with paired female personifications of abstract concepts-appears to have gone unnoticed.

A twelfth-century panegyrical text that builds on centuries-old eschatological traditions strengthens the association of Ecclesia and Synagoga with the Bamberg Rider. ${ }^{128}$ This work, a liturgical drama known as the Play of the Antichrist (Ludus de Antichristo), features a Staufen emperor who, as the Last World Emperor, unifies all the kingdoms of the earth, proceeds to the Holy Land, and fights the Antichrist as female personifications of the Church, the Synagogue, and a third figure, pagan religion (Gentilitas), stand by. ${ }^{129}$ Scholars long have suggested that this play or others like it may have influenced the representations of Ecclesia and Synagoga at Bamberg and other centers. ${ }^{130}$ But the parallels between the personae in the play and those adorning the exterior and the interior at Bamberg also are apparent.

It is particularly suggestive that the monastery housing the single surviving manuscript exemplar of the complete drama (now Munich, Staatsbibliothek, MS lat. 19411), ${ }^{131}$ the Benedictine abbey at Tegernsee, was a foundation held by the Andechs-Meran clan, that is, the family of bishops Ekbert and Poppo. ${ }^{132}$ Indeed, it is possible that an Andechs-Meran ancestor, Margarve Berthold III von Istria (d. 1188), who possessed lands in the diocese of Bamberg and whose brother was Bishop Otto II of Bamberg, borrowed books from the

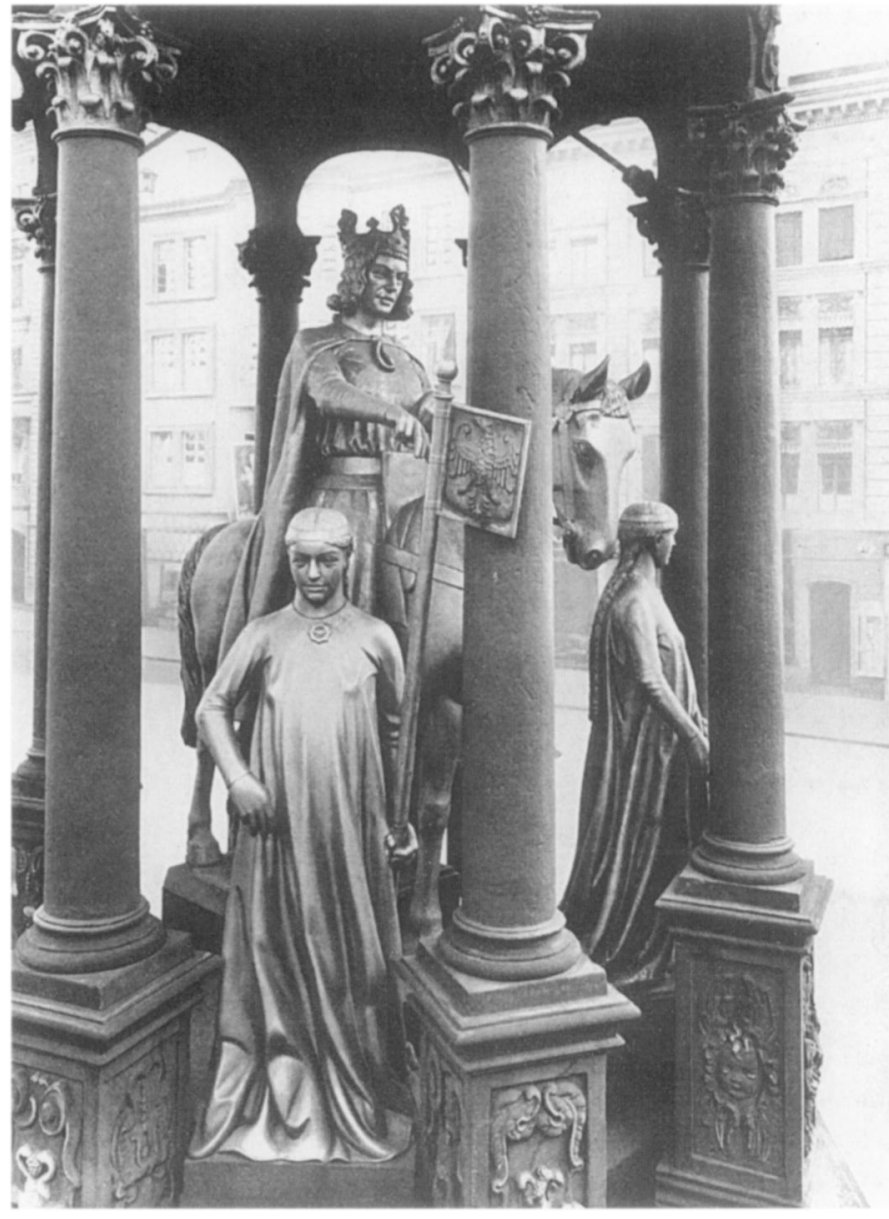

FIGURE 34. Magdeburg Rider (photo: SLUB Dresden / Deutsche Fotothek).

Tegernsee library. ${ }^{133}$ The manuscript containing the Ludus text is a 139 -folio miscellany containing works on grammar, style, epistolary forms, poetry, and letters, as well as a large excerpt of Otto of Freising's Gesta Friderici. ${ }^{134}$ It was compiled in the late twelfth or early thirteenth century, and the Ludus portion (fols. 2v-7) dates to about 1178-1186. Although there is no evidence that this manuscript traveled, it is possible that it was lent out. Whatever the case, the cast of characters in the Play of the Antichrist suggests that female personifications of world faiths-Christianity, Judaism, and paganism - were figurae established in the lexicon of Staufen panegyric. The circumstantial evidence linking the play to the circle of bishops Ekbert and Poppo bolsters the suggestion that the clerics of Bamberg conceived of Ecclesia and Synagoga on the exterior of the Fürstenportal as pendants to the Rider sculpture within.

The Bamberg Rider, presented with all the attributes of an ideal ruler, seemed to halt his steed and gaze toward the clerics as they sat in the cathedral's west choir. If the Bamberg bishop and his retinue reflected on the current world order as they looked at the Rider, they could draw on a wealth of 
imperial panegyric to direct their meditations. Nicholas of Bari exemplifies the prevailing rhetoric in an ode to the emperor whom he hails as a ruler who fulfilled sacred prophecies, an earthly echo of Christ:

[T]he exceptional prophet King David, in his authority, foretold of the greatness of two commanders, namely the heavenly emperor who commands the winds and the sea, who spoke and things were made, who ordered and the universe was created. And ruling the earth there is the magnificent emperor Frederick, anointed with the joyous oil before all the kings of the world. First he [David] prophesied the son [Christ], second [he prophesied] Christ's successor in the empire [Frederick]. ${ }^{135}$

Throughout Frederick's reign supporters cast him as mediator between the earthly and the heavenly realms and as motor of cosmic history, an epoch-making ruler who would usher in the end of time and thus speed Christ's return to earth to judge humanity. ${ }^{136}$ More specific to the theme of entry, by the thirteenth century it was traditional that when a ruler made a ceremonial entry into a city (adventus) he would be celebrated as bringer of a golden age, a leader whose presence transformed the site into a new Zion. ${ }^{137}$ Frederick II indeed had succeeded in entering the real Jerusalem and having himself crowned king of that city in the Church of the Holy Sepulchre in March 1229. This act echoed the long-standing prophecies about the Last German Emperor entering the holy city and inaugurating the end of time, prophecies that had been revived in texts such as the Play of the Antichrist. ${ }^{138}$ Imperial allies embraced the notion that the emperor's successes in the East forged an equation between the biblical ruler of Israel, King David, and the present king of Jerusalem, Frederick. These encomia are all the more remarkable because the emperor was an excommunicate at the time. ${ }^{139}$ Bishop Ekbert, having spent months and years with the imperial court, as well as his successor and the Bamberg clerics, would have been well acquainted with this network of imperial idealizations. The Bamberg Rider may not have been created to illustrate such notions literally. But his placement directly inside a portal whose tympanum presents the Last Judgment, the figure's lifelikeness, and its grandeur invited the Bamberg clerics who looked at the Rider to consider him in relation to such tropes.

\section{Style and the Balance of Power}

In the 1230 s, to attain stability in the realm, Emperor Frederick II established new controls over the Jews of the
German empire. Authority over Jews manifested in microcosm the emperor's authority over the whole of the imperial domain. These political moves built on theological justifications for the enduring presence of Jews within Christian society. Jews were considered the Lord's original "chosen," keepers of the Old Testament who at the end of time might convert to Christianity. Safeguarding them was thus part of a divine plan. Because Jews constituted a necessary population within the civic machinery, while taxes and municipal surveillance ensured their submission, bishops Ekbert and Poppo, in the first half of the thirteenth century, succeeded in integrating the local Jews within the social structure of Bamberg, thereby fulfilling papal prescriptions.

At the Fürstenportal of Bamberg Cathedral, a valiant king, a triumphant Ecclesia, and a vanquished Synagoga, against the backdrop of a scene of divine justice, collectively advanced a fiction of the rectitude of Jewish protection and repression as metonym for cosmic stability. Synagoga appears as a comely yet powerless member of the Christian retinue. In keeping with theological notions of outward beauty as a marker of inner spiritual merit, she is as well proportioned, serene, and lovely as her neighbor Ecclesia. She is a constitutive, indeed necessary, member of the City of God. Her beauty underscores the notion that she belongs among the panoply of figures populating a divinely ordered society. Her physiological lassitude, broken staff, and blindfold, however, brand her as a weakling whose very repression is sanctioned under the current world order.

Style and form were the vehicles for this message. The "younger" workshop sculptors experimented with a new visual mode, presenting idealized figurations in lifelike and dramatic guises. Bodies are anatomically coherent; gestures are expressive; gravity seems to weigh down drapery-all this, and vivid polychrome, too. These visual features invited audiences to understand the world projected in stone on the cathedral as one in dialogue with earthly existence. Naturalistic form wordlessly insisted that dogmatic visual projections conveyed realworld truths.

The clerics at Bamberg Cathedral could view the Fürstenportal complex and find comfort that under the current world order, cosmic harmony would endure. At the end of time the righteous will find their reward with Christ, and the sinful will be enslaved to Satan. In the meantime, a divinely sanctioned ruler administers the empire justly. Under him, cosmic oppositions are brought into balance. Under him the Church stands strong, ensuring salvation for her followers. Under him, Jewsarchetypal transgressors yet constitutive members of the Christian universe - are rendered impotent and kept at the margins of society. Remove Synagoga from this delicately balanced constellation, and the whole edifice collapses. 
* Research for this article was funded by the Leo Baeck Foundation, the Deutscher Akademischer Austausch Dienst, the Memorial Foundation for Jewish Culture, and Northwestern University. Thanks to Sandra Hindman, Karl Werckmeister, and Larry Silver for guiding me through the dissertation from which this article draws (Northwestern University, Evanston, IL, 2002) and especially to Joyce, Gerald, and Claudia Rowe for their unceasing encouragement. A version of this article was presented at a session in honor and memory of Jane Welch Williams at the 34th Annual Congress on Medieval Studies, Kalamazoo, MI, May 1999. I am grateful to Barbara Abou-El-Haj for including me on the panel. This text benefited immensely from the critiques and suggestions of anonymous Gesta reviewers as well as many friends and colleagues. Particular thanks are due to Robert Lerner, Mitchell Merback, Janine Mileaf, Stephen Perkinson, Liz Spikol, Claudia Swan, and Achim Timmermann, and also to Elizabeth Sears and Anne D. Hedeman for editorial interest in my work and guidance. I thank Cornell Owesny for proofing Latin translations and Wes Evard for assistance with Photoshop. Finally, I dedicate this article to Glenn Hendler, who helped me through multiple drafts of this text and so much more.

1. This portal was dubbed the "Fürstentor" (Princes' Portal) in the eighteenth century; a 1583-1584 source calls the portal the "Ehethür" (Portal of Honor). See R. Kroos, "Liturgische Quellen zum Bamberger Dom," ZfKg, XXXIX/2-3 (1976), 105-146, at 110-112. This article was reprinted in the chief monograph on the architecture of Bamberg cathedral, D. von Winterfeld, Der Dom in Bamberg, 2 vols. (Berlin, 1979), I, 160-176 (subsequent references are to pages in $\mathrm{ZfKg}$ ).

2. On the social makeup of Bamberg in the Middle Ages, see B. Schimmelpfennig, Bamberg im Mittelalter: Siedelgebiete und Bevölkerung bis 1370 (Historische Studien, CCCXCI) (Lübeck, 1964), 36-39, 46-47, and $69-82$.

3. Schimmelpfennig, Bamberg im Mittelalter, 12-17; and J. Zeune, "Die Bamberger Bischofspfalz," in Bamberg, Historisches Museum Bamberg, Die Andechs-Meranier in Franken: Europäisches Fürstentum im Hochmittelalter (Mainz, 1998), ed. U. Vorwerk and E. Schurr, 203-207.

4. On the cathedral square as the site of the Bamberg bishop's court, see A. Erler, Das Straßburger Münster im Rechtsleben des Mittelalters (Frankfurt am Main, 1954), 30-32; R. Neumüllers-Klauser, "Der Bamberger Dom als Stätte mittelalterlicher Rechtspflege," Bericht des Historischen Vereins Bamberg, CII (1966), 177-189; and Kroos, "Liturgische Quellen," 112. There is also evidence that the pillar on which Synagoga stands was used as a whipping post for the accused and condemned. See Erler, Das Straßburger Münster, 31-32. On medieval buildings and artworks as symbols of justice in general, though without direct discussion of Bamberg, see K. Frölich, Mittelalterliche Bauwerke als Rechtsdenkmäler (Tübingen, 1939).

5. On Franciscans in Bamberg, see H. Paschke, "Das Franziskanerkloster an der Schranne zu Bamberg," Bericht des Historichen Vereins Bamberg, CX (1974), 169-314. On Franciscan anti-Jewish polemic, see J. Cohen, The Friars and the Jews: The Evolution of Medieval AntiJudaism (Ithaca, NY, 1982).

6. See the remarks of T. Breuer, "Der Bamberger Dom in seiner Stadtund Landschaft," in Hortulus floridus bambergensis: Studien zur fränkischen Kunst- und Kulturgeschichte. Renate Baumgärtel-Fleischmann zum 4. Mai 2002, ed. W. Taegert (Petersberg, 2004), 19-34, at 24-25.

7. For example, W. Boeck, Der Bamberger Meister (Tübingen, 1960), 12; though see the remarks of Kroos, "Liturgische Quellen," 113-114. On Bamberg's sainted imperial founders, see R. Klauser, "Der Heinrichsund Kunigundenkult im mittelalterlichen Bistum Bamberg," Bericht des Historischen Vereins Bamberg, XCV (1957), 1-208; and K. Guth, Kaiser Heinrich II. und Kaiserin Kunigunde: Das heilige Herrscherpaar-Leben, Legende, Kult und Kunst (Petersberg, 2002).
8. The principal parish church in early-thirteenth-century Bamberg was the Obere Pfarrkirche (Upper Parish Church), also known as Unsere Liebe Frau. See H. Mayer, Die Obere Pfarrkirche zu Bamberg (Bamberg, 1929); and H. Paschke, Unter unserer lieben Frauen Pfarre zu Bamberg (Bamberg, 1967).

9. On the installation of the Bamberg Rider, see note 109 below.

10. Many now identify the Bamberg Rider with St. Stephen of Hungary. If they are right, he is not strictly an "earthly authority." I address this issue below.

11. This claim pertains to the situation at Bamberg as well as other contexts across northern Europe dating from the early thirteenth century on. Examples of the Ecclesia-Synagoga motif on cathedral facades include the cathedrals at Reims, south facade (ca. 1220-1235) and Chartres, north porch (destroyed) (ca. 1220); the church of Sainte-Madeleine at Besançon (destroyed) (ca. 1220-1230); the cathedrals at Strasbourg, south facade (ca. 1220-1235) and Magdeburg, north facade (ca. 1250); the Liebfraukirche at Trier, west facade (ca. 1250); the church of SaintSeurin at Bordeaux, south facade (ca. 1270); the castle chapel at Marienburg (Malbork), upper portal (ca. 1270-1280); the cathedrals at Minden, western narthex (severely damaged) (ca. 1275), Freiburg im Breisgau, west porch (ca. 1290-1295), Worms, south facade (ca. 1300) and Lincoln Cathedral, south side (now headless) (ca. 1260-1270); the church of Saint Peter at Wimpfen im Tal, south facade (ca. 1300); and the cathedrals at Béziers, west facade (fourteenth century) and Erfurt, west facade (ca. 1335).

12. Principal studies are P. Weber, Geistliches Schauspiel und kirchliche Kunst in ihrem Verhältnis erläutert an einer Ikonographie der Kirche und Synagoge (Stuttgart, 1894); W. S. Seiferth, Synagogue and Church in the Middle Ages: Two Symbols in Art and Literature, trans. L. Chadeayne and P. Gottwald (New York, 1970); and Essen, Alte Synagoge, and Saarbrücken, Regionalgeschichtliches Museum, Ecclesia und Synagoga: Das Judentum in der christlichen Kunst, ed. H. Jochum (Essen, 1993). See also the more narrowly focused studies A. Raddatz, "Die Entstehung des Motivs 'Ecclesia und Synagoge': Geschichtliche Hintergründe und Deutung" (Dissertation, Humboldt-Universität, Berlin, 1959); and B. Blumenkranz, "Géographie historique d'un thème de l'iconographie religieuse: les représentations de Synagoga en France," in Mélanges offerts à René Crozet (Poitiers, 1966), II, 1141-1157. Iconographic encyclopedias include A. Weis, "Ekklesia und Synagoge," in Reallexikon zur deutschen Kunstgeschichte, ed. E. Gall and L. H. Heydenreich (Stuttgart, 1958), IV, 1189-1215; W. Greisenegger, "Ecclesia und Synagoge," in Lexikon der christlichen Ikonographie, ed. E. Kirschbaum (Rome, 1968), I, 569-578; and G. Schiller, Ikonographie der christlichen Kunst (Gütersloh, 1976), IV, Part 1, 45-68. See also the sources cited in note 14 below.

13. On this issue, see G. Didi-Huberman, Confronting Images: Questioning the Ends of a Certain History of Art (University Park, PA, 2005); H. Damisch, "Semiotics and Iconography," in The Tell-Tale Sign: A Survey of Semiotics, ed. T. Sebeok (Lisse, 1975), 27-36; W. J. T. Mitchell, Iconology: Image, Text, Ideology (Chicago, 1986), esp. 151159; B. Cassidy, "Introduction: Iconography, Texts, and Audiences," in Iconography at the Crossroads, ed. Cassidy (Princeton, 1993), 3-15; and H. Bredekamp, "Words, Images, Ellipses," in Meaning in the Visual Arts: Views from the Outside, ed. I. Lavin (Princeton, 1995), 363-371.

14. Recently scholars have begun to consider the physical qualities of sculptures of Ecclesia and Synagoga, though without direct discussion of political contexts. See H. Sciurie, "Ecclesia und Synagoge: Bilder von Sinnlichkeit und Gewalt am deutschen Kirchenportal des 13. Jahrhunderts," in Blick-Wechsel: Konstruktionen von Männlichkeit und Weiblichkeit in Kunst und Kunstgeschichte, ed. I. Lindner et al. (Berlin, 1989), 
243-250; eadem, "Ecclesia und Synagoge an den Domen zu Straßburg, Bamberg, Magdeburg und Erfurt: Körpersprachliche Wandlungen im gestalterischen Kontext," Wiener Jahrbuch für Kunstgeschichte, XLVIXLVII (1993-1994), 679-687 and 871-874; and A. Weber, "Glaube und Wissen-Ecclesia et Synagoga," in Wissenspopularisierung: Konzepte der Wissensverbreitung im Wandel, ed. C. Kretschmann (Berlin, 2003), 89-126. Others also have begun to examine instances of Ecclesia and Synagoga in narrower historical, material, and iconographic contexts. Noteworthy examples are A. Timmermann, "The Avenging Crucifix: Some Observations on the Iconography of the Living Cross," Gesta, XL/2 (2001), 141-160; and S. Lipton, "The Temple Is My Body: Gender, Carnality and Synagoga in the Bible moralisée," in Imagining the Self, Imagining the Other: Visual Representation and JewishChristian Dynamics in the Middle Ages and Early Modern Period, ed. E. Frojmovic (Leiden, 2002), 129-163. In another article I interrogate the sculptures of Ecclesia and Synagoga at Strasbourg Cathedral in explicitly political terms. See N. Rowe, "Idealization and Subjection at the South Porch of Strasbourg Cathedral," in Beyond the Yellow Badge: Anti-Judaism, Antisemitism and European Visual Culture before 1800, ed. M. Merback (Leiden, forthcoming).

15. The principal monograph on the architecture of Bamberg Cathedral is Winterfeld, Der Dom in Bamberg. For a general overview of the history of the cathedral, see A. F. von Reitzenstein, Die Geschichte des Bamberger Domes: von den Anfüngen bis zu seiner Vollendung im 13. Jahrhundert (Munich, 1984). An important recent study on the chronology of the Fürstenportal is M. Schuller, Das Fürstenportal des Bamberger Domes (Bamberg, 1993).

16. Classic discussions of the Bamberg sculpture are W. Vöge, "Über die Bamberger Domskulpturen," Repertorium für Kunstwissenschaft, XXII (1899), 94-104, and XXIV (1901), 195-229 and 255-289; idem, "Die Bamberger Domstatuen, ihre Aufstellung und Deutung," Zeitschrift für christliche Kunst, XV (1902), 357-368 (these articles are reprinted in Bildhauer des Mittelalters: gesammelte Studien von Wilhelm Vöge [Berlin, 1958], 130-209); H. Jantzen, Deutsche Bildhauer des dreizehnten Jahrhunderts (Leipzig, 1925; rpt. Berlin, 2001), 72-178; W. Pinder, Der Bamberger Dom und seine Bildwerke (Berlin, 1927); Boeck, Der Bamberger Meister; and H. Fiedler, Magister de vivis lapidibus: Der Meister im Bamberger Dom (Kempten im Allgäu, 1965). A useful and accessible introduction appears in P. Williamson, Gothic Sculpture, 1140-1300 (New Haven, 1995), 91-98. The latest findings on both the architecture and sculpture of Bamberg are in a special edition of Das Münster, edited by A. Hubel and M. Schuller, "Sonderheft: Bamberger Dom-Architektur, Skulptur, neue Glasfenster,” Das Münster: Zeitschrift für christliche Kunst und Kunstwissenschaft, LVI/5 (2003).

17. See note 39 below.

18. R. Suckale, "Die Bamberger Domskulpturen: Technik, Blockbehandlung, Ansichtigkeit und die Einbeziehung des Betrachters," Münchner Jahrbuch der Bildenden Kunst, XXXVIII (1987), 27-82.

19. Recent scholarship that informs my own study of Bamberg Cathedral as an image environment includes B. Abou-El-Haj, "The Urban Setting for Late Medieval Church Building: Reims and Its Cathedral between 1210 and 1240," $A H, \mathrm{XI} / 1$ (1988), 17-41; W. Kemp, "Kunstwissenschaft und Rezeptionsästhetik," in Der Betrachter ist im Bild: Kunstwissenschaft und Rezeptionsästhetik, ed. Kemp (Cologne, 1985), 7-27; L. Spitzer, "The Cult of the Virgin and Gothic Sculpture: Evaluating Opposition in the Chartres West Façade Capital Frieze," Gesta, XXXIII/2 (1994), 132-150; V. C. Raguin, K. Brush, and P. Draper eds., Artistic Integration in Gothic Buildings (Toronto, 1995); J. Jung, "Beyond the Barrier: The Unifying Role of the Choir Screen in Gothic Churches," $A B$, LXXXII/4 (2000), 622-657; eadem, "Peasant Meal or Lord's Feast? The Social Iconography of the Naumburg Last Supper," Gesta, XLII/1 (2003), 36-61; and M. T. Davis, "Canonical Views: The
Theophilus Story and the Choir Reliefs at Notre-Dame, Paris," in Reading Medieval Images: The Art Historian and the Object, ed. E. Sears and T. K. Thomas (Ann Arbor, 2002), 103-116.

20. See W. Iser, The Act of Reading: A Theory of Aesthetic Response (Baltimore, 1978), esp. 107-134; S. Fish, "Is There a Text in This Class?" in Is There a Text in This Class? The Authority of Interpretive Communities (Cambridge, MA, 1980), 303-321; and H. R. Jauss, Toward an Aesthetic of Reception, trans. T. Bahti (Minneapolis, 1982), passim. Brian Stock first applied concepts from reception theory to medieval examples, examining communal identities forged around texts-what Stock terms "textual communities." See B. Stock, The Implications of Literacy: Written Language and Models of Interpretation in the Eleventh and Twelfth Centuries (Princeton, 1983); as well as idem, "Textual Communities: Judaism, Christianity, and the Definitional Problem," in Listening for the Text: On the Uses of the Past (Baltimore, 1990), 140-158.

21. As will be discussed, Ekbert's reign is marked by a strong adherence to the Hohenstaufen. Poppo apparently continued to support this imperial family until 1242, when he took the side of Frederick II's enemies in the emperor's dispute with the pope. As a result of the betrayal, Poppo was stripped of his title as bishop of Bamberg. Between the reigns of bishops Ekbert and Poppo there was the brief interregnum of Siegfried von Öttingen, which lasted one or two months. On Siegfried and Poppo, see E. Freiherr von Guttenberg, Das Bistum Bamberg (Berlin, 1937), 170-173. On Poppo, see A. Frenken, "Poppo, Dompropst und Electus Bambergensis: Ein unterschätzter Protagonist Andechser Hausmachtpolitik in Franken," Bericht des Historischen Vereins Bamberg, CXXXVII (2001), 169-184.

22. That Ekbert's canons may not have always behaved loyally is suggested by Ekbert's ruling stating that if the deacon should fail in the administration of corrective measures against the canons, then the bishop may step in and exercise his authority using violence. Guttenberg, Das Bistum Bamberg, 86. On subsequent relations between the chapter and the bishops of Bamberg, see S. Bachmann, "Die Landstände des Hochstifts Bamberg: ein Beitrag zur territorialen Verfassungsgeschichte," Bericht des Historischen Vereins Bamberg, XCVIII (1962), 3-320, at 34-39. See also Schimmelpfennig, Bamberg im Mittelalter, 92-93; Guttenberg, Das Bistum Bamberg, 61-62; and R. Neumüllers-Klauser, "Die Quellen zur Baugeschichte des Ekbert-Domes," in Winterfeld, Der Dom in Bamberg, I, 30-37, at 33-34.

23. This restoration was carried out at the request of King Ludwig I of Bavaria. The king's restorer, Friedrich Karl Rupprecht, kept journals recording the work, now housed in the Archiv des Erzbistums in Bamberg. In the early 1930s Alexander Freiherr von Reitzenstein created a typescript of selections from these notebooks. Reitzenstein's transcriptions remain unpublished, but copies are housed in the Staatsbibliothek of Bamberg and the Bayerisches Landesamt für Denkmalpflege in Munich under the titles "Akten zur Geschichte des Bamberger Domes: Restaurierung 1826/1841" (n.d., ca. 1934) and "Die Veränderungen des Bamberger Domes in den Jahren 1828/44" (n.d., ca. 1934). On Rupprecht's project, see A. Hubel, "Die beiden Restaurationen des Bamberger Domes: zur Geschichte der Denkmalpflege im frühen 19. Jahrhundert," Bericht des Historischen Vereins Bamberg, CXXI (1985), 45-90. Analysis of Reitzenstein's typescripts and further evidence on the restoration is found in C. Hans-Schuller, Der Bamberger Dom: seine "Restauration" unter König Ludwig I. von Bayern (1826-31) (Petersberg, 2000).

24. Schuller, Das Fürstenportal, 12.

25. In 1778 the level of the street in front of the Fürstenportal was lowered. Its level in the thirteenth century remains unknown. See Winterfeld, Der Dom in Bamberg, II, 13-14; and Schuller, Das Fürstenportal, 37-39. This fact further frustrates a precise re-creation of the original viewing 
experience of the Fürstenportal. For commentary on this problem, see Suckale, "Die Bamberger Domskulpturen," 59 and 79, note 112.

26. For examination of this and related issues, see R. Nelson, "Introduction: Descartes's Cow and Other Domestications of the Visual," in Visuality before and beyond the Renaissance: Seeing as Others Saw, ed. Nelson (Cambridge, 2002), 1-21; the essays in The Mind's Eye: Art and Theological Argument in the Middle Ages, ed. J. Hamburger and A.-M. Bouché (Princeton, 2006); as well as the useful overview in C. Hahn, "Vision," in A Companion to Medieval Art: Romanesque and Gothic in Northern Europe, ed. C. Rudolph (Oxford, 2006), 44-64. I am grateful to Cynthia Hahn for sharing her text with me before publication.

27. On the history of Bamberg, see Guttenberg, Das Bistum Bamberg; J. Kist, Fürst- und Erzbistum Bamberg: Leitfaden durch ihre Geschichte von 1007 bis 1960 (Bamberg, 1962); Schimmelpfennig, Bamberg im Mittelalter; and O. Meyer et al., Oberfranken im Hochmittelalter: Politik-Kultur-Gesellschaft (Bayreuth, 1973).

28. On Henry II's donations to Bamberg and other centers, see E. Garrison, "The Art Policy of Emperor Henry II (1002-1024)" (Dissertation, Northwestern University, Evanston, IL, 2005).

29. On Bishop Ekbert, see E. Hautum, "Ekbert von Meran, Bischof von Bamberg, 1203-1237" (Dissertation, Friedrich-Alexander-Universität, Erlangen, 1924); and S. Beulertz, "Ekbert von Andechs: Bischof von Bamberg (1203-1237)," Fränkische Lebensbilder, XVII (1998), 9-22. The most up-to-date works on the Andechs-Meran clan in general are Kloster Andechs, Haus der Bayerischen Geschichte, Herzöge und Heilige: das Geschlecht der Andechs-Meranier im europäischen Hochmittelalter (Regensburg, 1993), ed. J. Kirmeier and E. Brockhoff; Bamberg, Die Andechs-Meranier in Franken; and A. Frenken, "Hausmachtpolitik und Bischofsstuhl: Die Andechs-Meranier als oberfränkische Territorialherren und Bischöfe von Bamberg," Zeitschrift für bayerische Landesgeschichte, LXIII (2000), 711-786. On the twelfthcentury history of the family, see J. R. Lyon, "Cooperation, Compromise and Conflict Avoidance: Family Relationships in the House of Andechs, ca. 1100-1204" (Dissertation, University of Notre Dame, IN, 2004).

30. On the events surrounding the wedding and their aftermath, see Hautum, "Ekbert von Meran," 20-25; P. Groebe, "Schuld und Mitschuld am Bamberger Königsmord," Fränkische Heimat, XVII (MayJune 1938), 80-83; W. Liebhart, "Der Königsmord von Bamberg (1208) und Pfalzgraf Otto VIII.," in Die Wittelsbacher im aichacher Land: Gedenkschrift der Stadt Aichach und des Landkreises Aichach-Friedberg zur 800-Jahr-Feier des Hauses Wittelsbach, ed. T. Grad (Aichach, 1980), 122-127; and the incisive analysis in B. U. Hucker, "Der Königsmord von 1208-Privatrache oder Staatsstreich?" in Bamberg, Die Andechs-Meranier in Franken, 111-127.

31. For summary, see Hautum, "Ekbert von Meran," 21.

32. Hucker, "Der Königsmord," 118-119.

33. A. Schütz, "Die Andechs-Meranier in Franken und ihre Rolle in der europäischen Politik des Hochmittelalters," in Bamberg, Die AndechsMeranier in Franken, 3-54, at 32-34.

34. On the negotiations behind the acquittal, see Hautum, "Ekbert von Meran," 25-31; and Schütz, "Die Andechs-Meranier," 34-36.

35. For decades scholars have dated the bulk of the rebuilding of Bamberg Cathedral to Ekbert von Andechs-Meran's episcopacy. But recently experts have argued that the project was advanced much earlier. For dating that places the inauguration of the project in the late twelfth century, see U. Vorwerk, "Die Andechs-Meranier und der Neubau des Bamberger Domes," in Bamberg, Die Andechs-Meranier in Franken, 209-218, esp. 213-214; and A. Hubel and M. Schuller, "Der Bamberger Dom als Erinnerungsort," in Bamberg, Haus der Bayerischen Geschichte, Kaiser Heinrich II., 1002-1024 (Stuttgart, 2002), J. Kirmeier et al., 388-391. For a review of the principal arguments on chronology, see U. Arnold, "Bemerkungen zu den Quellen der Baugeschichte des Bamberger Domes im 13. Jahrhundert," Bericht des Historischen Vereins Bamberg, CVI (1970), 13-20; and Winterfeld, Der Dom in Bamberg, I, 141-145, and passim. For important commentary that lays out key questions regarding the building's chronology, see R. Suckale, "Nach Dethard von Winterfelds Monographie über den Bamberger Dom: zum Stand der Erforschung der Domarchitektur-mit einem Hinweis auf die Bauweise des Fürstenportals," Bericht des Historischen Vereins Bamberg, CXXIII (1987), 161-169.

36. A. Hubel and M. Schuller, "Überlegungen zur frühen Baugeschichte des Bamberger Doms," "Sonderheft: Bamberger Dom," 310-325, esp. 321322; and A. Hubel, "Die älterere Bildhauerwerkstatt des Bamberger Doms," ibid., 326-346. The 1225 date for the completion of the Fürstenportal was first demonstrated in Schuller, Das Fürstenportal, 7 and 90.

37. On this fire and the later history of the building, see M. Schuller, "Eine Brandkatastrophe und ihre späten Folgen: die barocken Sanierungsarbeiten am Bamberger Dom," in Hortulus floridus bambergensis, 43-62.

38. The stylistic affinities between sculptures at Bamberg and Reims are analyzed systematically in W. Sauerländer, "Reims und Bamberg: zu Art und Umfang der Übernahmen,” ZfKg, XXXIX/2-3 (1976), 167-192; and H.-C. Feldmann, Bamberg und Reims: Die Skulpturen, 1220-1250 (Ammersbek bei Hamburg, 1992). See also idem, "Bamberg. Bauhüttenbetriebe im Vergleich: zur Dominanz von Meistern im Bauhüttenbetrieb und ihre Einflußnahme auf die Konzeption und Ausführung von Skulpturenprogrammen," in Studien zur Geschichte der europäischen Skulptur im 12./13. Jahrhundert, ed. H. Beck and K. Hengevoss-Dürkop, 2 vols. (Frankfurt, 1994), I, 87-99, and II, 24-36. Worth mention is Suckale's insistence on the distinction between the Bamberg sculpture and contemporary French works. See Suckale, "Die Bamberger Domskulpturen," esp. $39,41,45,52,53,76$ note 63 and 77 note 74 .

39. Feldmann contends that the "younger" workshop arrived in Bamberg ca. 1228 (Bamberg und Reims, 98-100); Sauerländer seems to suggest they came in the 1230s ("Reims und Bamberg," 190-192); and Paul Williamson dates the arrival to ca. 1233-1234 (Gothic Sculpture, 93-94). For a discussion of the archaeology of the Fürstenportal, supporting the arrival of the "younger" workshop to the 1220 s, see Schuller, Das Fürstenportal, 63-90 and 98, for discussion of the implications for the chronology of other monuments.

40. For more on these, see notes 109 and 119 below.

41. Discussion of Frederick II draws on T. C. Van Cleve, The Emperor Frederick II of Hohenstaufen: Immutator Mundi (Oxford, 1972); D. Abulafia, Frederick II: A Medieval Emperor (London, 1988); and E. Kantorowicz, Frederick the Second, 1194-1250, trans. E. O. Lorimer (New York, 1957).

42. I am not the first to consider Ekbert's crusade as an expiatory act. J. R. Sweeney, "Hungary in the Crusades, 1169-1218," The International History Review, III/4 (1981), 467-481, esp. 478-479.

43. There is little information on Ekbert's activity on crusade. For scattered references, see Hautum, "Ekbert von Meran," 35-38; R. Röhricht, Studien zur Geschichte des fünften Kreuzzuges (1891; rpt. Aalen, 1968), 84; and Oliverus Scholasticus, Die Schriften des Kölner Domscholasters, späteren Bischofs von Paderborn und Kardinal-Bischofs von S. Sabina, ed. H. Hoogeweg (Tübingen, 1894), 162-163 and 168. On the venture, though with little direct discussion of Ekbert, see J. M. Powell, Anatomy of a Crusade, 1213-1221 (Philadelphia, 1986), 123-135.

44. For Ekbert's itinerary, see Neumüllers-Klauser, "Die Quellen,” 36.

45. The contract of the settlement designates the funds "ad opus et utilitatem ecclesie sue," suggesting that much of the new influx of cash went to the cathedral building project. For the full passage and analysis, see Neumüllers-Klauser, "Die Quellen," 32-33. 
46. Neumüllers-Klauser argues that the linguistic construction within the treaty (cited in note 45 above) unquestionably earmarks the funds given by the emperor as a donation to the Bamberg Cathedral building project (ibid., 32-33). This contention is repeated or suggested in literature ranging from monographs to surveys. See W. R. Valentiner, The Bamberg Rider: Studies of Medieval German Sculpture (Los Angeles, 1956), 105; and Williamson, Gothic Sculpture, 91. But recently Klaus van Eickels has observed that the term opus in the document by no means necessarily refers to the cathedral's construction. Rather, the formulation "ad opus" in the context of the treaty simply signifies "for the benefit of" Bamberg Cathedral or Ekbert as representative of the institution. Further, he holds that a sum of four thousand silver marks was not excessive, and indeed it was a fair compensation for damages. $K$. van Eickels, "Die Andechs-Meranier und das Bistum Bamberg," in Bamberg, Die Andechs-Meranier in Franken, 145-156, at 155 note 41.

47. Discussed in Vorwerk, "Die Andechs-Meranier und der Neubau des Bamberger Domes," 215-216.

48. "ut hanc habeat libertatem et prerogatiuam inter cetera altaria ut nec prepositus nec decanus aut thesaurarius sive subcostus aut ullus illorum qui dicuntur ecclesiastici seu campanarii unquam aliquid iuris sibi uendicent in eo similiter et in sacerdote in illo celebrante qui ad solum episcopum habere debet respectum." From A. F. von Reitzenstein, "Die Baugeschichte des Bamberger Domes," Münchner Jahrbuch der bildenden Kunst, XI (1934), 113-152, at 149.

49. On the following, Hautum, "Ekbert von Meran," 41-47.

50. Ibid., 57-68.

51. Ibid., 42 and $47-57$.

52. In opposition to traditional literature that dubs the cathedral the "EkbertDom" (see note 35 above), scholars now stress the primary role of the chapter in the completion of the structure. See Hubel and Schuller, "Der Bamberger Dom als Erinnerungsort"; and idem, "Überlegungen zur frühen Baugeschichte," 313-314; and Frenken, "Poppo, Dompropst und Electus Bambergensis," 176-178. For a compilation of all the documents on the relation of the chapter to the cathdral, see H. Paschke, Das Domstift zu Bamberg in seinen Bauwendungen (Studien zur Bamberger Geschichte und Topographie, XLIV-XLVII) (Bamberg, 1972).

53. What follows is an analysis of the Fürstenportal as experienced during a ritual entrance to the cathedral. Many ecclesiastical rituals, however, entailed more than simple entry into the church. For instance, on feast days, the local ecclesiastical hierarchy made processions throughout the city of Bamberg, though the cathedral typically remained the departure point for these peregrinations. See X. Haimerl, Das Prozessionswesen des Bistums Bamberg im Mittelalter (Munich, 1937; rpt. Hildesheim, 1973). Furthermore, the Fürstenportal was not the only door used for ceremonial entrances. The northeast entrance (Gnadenpforte), for example, was used during Easter rituals. See P. Wünsche, "Die Kathedrale als heilige Stadt: zur liturgischen Topographie des Bamberger Doms," in Heiliger Raum: Architektur, Kunst und Liturgie im mittelalterlichen Kathedralen und Stiftskirchen, ed. F. Kohlschein and Wünsche (Münster, 1998), 25-58; this article repeats some of the findings in idem, Kathedralliturgie zwischen Tradition und Wandel: zur mittelalterlichen Geschichte der Bamberger Domliturgie im Bereich des Triduum Sacrum (Münster, 1998).

54. See Wünsche, "Die Kathedrale als heilige Stadt," 27 and note 7.

55. There are no early drawings recording the original arm gestures and attributes of Ecclesia at Bamberg, but comparison with roughly contemporaneous monumental sculptures at Reims, Strasbourg, Magdeburg, Trier, and other centers (see note 11 above) strongly suggests that she carried a chalice and triumphal banner or spear.
56. An important starting point for any analysis of high medieval sculptural styles is P. C. Claussen, "Zentrum, Peripherie, Transperipherie: Überlegungen zum Erfolg des gotischen Figurenportals an den Beispielen Chartres, Sangüesa, Magdeburg, Bamberg und den Westportalen des Domes S. Lorenzo in Genua," in Studien zur Geschichte der europäischen Skulptur, I, 665-687, and II, 424-449. See also W. Sauerländer, "Intentio vera nostra est manifestare ea, que sunt, sicut sunt: Bildtradition und Wirklichkeitserfahrung im Spannungsfeld der staufischen Kunst," in Stauferzeit: Geschichte-Literatur-Kunst, ed. R. Krohn, B. Thum, and P. Wapnewski (Stuttgart, 1978), I, 119-131 (rpt. in W. Sauerländer, Cathedrals and Sculpture [London, 1999], I, 369-392); and K. Flasch, "Ars imitatur naturam: Platonischer Naturbegriff und mittelalterliche Philosophie der Kunst," in Parusia: Festgabe für Johannes Hirschberger, ed. Flasch (Frankfurt am Main, 1965), 265-306. An important examination of the cruel power of realistic style is M. B. Merback, The Thief, the Cross, and the Wheel: Pain and the Spectacle of Punishment in Medieval and Renaissance Europe (Chicago, 1999), a study that influences my own approach.

57. It must be noted that members of the so-called older workshop also created sculptures marked by dramatic gesture and drapery, such as the reliefs at the northwestern end of the eastern Georgenchor choir screen.

58. Walter Hartleitner has analyzed traces of the multiple layers of paint (all in monochrome) on the Fürstenportal tympanum. It seems that originally the tympanum was covered with a pink-colored ocher paint with a lime-casein binder, perhaps on a thin white ground. See W. Hartleitner, "Zur Polychromie der Bamberger Domskulptur," "Sonderheft: Bamberger Dom," 366-380, at 373-375. Hartleitner generously shared his findings with me in two meetings, in November 1997 and June 2000.

59. On the polychrome of Ecclesia and Synagoga, see Hartleitner, "Zur Polychromie der Bamberger Domskulptur," 374. Hartleitner's research supersedes assessments offered in Suckale, "Die Bamberger Domskulpturen," 32; and Schuller, Das Fürstenportal, 115 note 239.

60. Hartleitner, "Zur Polychromie der Bamberger Domskulptur," 373-374. Hartleitner, though, is careful to point to the possibility that the paint could have been added up to two decades after the creation of the sculptures; ibid., 376-377.

61. This is a presumption that drives much recent art historical inquiry on thirteenth-century monumental art. Exemplary studies are Abou-El-Haj, "The Urban Setting for Late Medieval Church Building"; and W. W. Clark, "Reading Reims, I. The Sculptures on the Chapel Buttresses," Gesta, XXXIX/2 (2000), 135-145.

62. For more, see G. Gebauer and C. Wulf, Mimesis: Culture-Art-Society, trans. D. Reneau (Berkeley, 1992), 1-8; and J. D. Lyons and S. G. Nichols, introduction to Mimesis: From Mirror to Method, Augustine to Descartes (Hanover, NH, 1982), 1-19, esp. 1-4, as well as the essays in that volume.

63. Discussed in R. A. Markus, Saeculum: History and Society in the Theology of St. Augustine (Cambridge, 1970), 72-104.

64. On this development, see E. H. Kantorowicz, The King's Two Bodies: A Study in Mediaeval Political Theology (Princeton, 1957; rpt. Princeton, 1997), 87-97.

65. Ibid., 97-143. Though see the comments of Abulafia, Frederick II: A Medieval Emperor, 202-203.

66. "ut eorum [the Jews] quilibet super vestimenta que induet gestet lineum uestimentum clauum undique et tinctum colore celesti et secundum sue tempus etatis barbam nutriat et barbatus incedat, ut hec inter orthodosos et ipsos sit differentia generalis, per quam mutuo discernantur et possint melius ab illicitis abstinere." Richard of San Germano, Chronica, in Rerum italicarum scriptores, ed. L. A. Muratori (Bologna, 1938), VII, 
Part II, 96. For more on distinguishing marks for Jews, see note 102 below.

67. J. R. Marcus, The Jew in the Medieval World: A Source Book, 315-1791 (Philadelphia, 1938; rpt. New York, 1975), 138-139. For the Latin, N. P. Tanner, Decrees of the Ecumenical Councils, I, Nicaea I to Lateran V (Washington, DC, 1990), 266, Canon 68. See also note 102 below.

68. Scholars have seen this action, ultimately a rejection of the ruling of the Fourth Lateran Council, as an affront to the papacy-that is, a maneuver within the larger power struggle between Frederick II and Pope Gregory IX. See S. Simonsohn, The Apostolic See and the Jews, VII, History (Toronto, 1991), 463-464 and 464 note 4, with further references.

69. Liber Augustalis, I, 1 and 18. See J. M. Powell, trans. and ed., The Liber Augustalis or Constitutions of Melfi Promulgated by the Emperor Frederick II for the Kingdom of Sicily in 1231 (Syracuse, NY, 1971), 7-9 and 22.

70. See, for example, Kantorowicz, Frederick the Second, 343-346; Van Cleve, The Emperor Frederick II, 239-240; and G. Wolf, "Kaiser Friedrich II. und die Juden: ein Beispiel für den Einfluß der Juden auf die mittelalterliche Geistesgeschichte," Judentum im Mittelalter: Beiträge zum christlich-jüdischen Gespräch, ed. P. Wilpert (Miscellanea Mediaevalia, IV) (Berlin, 1966), 435-441.

71. For a concise statement on the range of approaches Frederick II took in his treatment of Jews-as well as Muslims-see D. Abulafia, "Ethnic Variety and Its Implications: Frederick II's Relations with Jews and Muslims," in Intellectual Life at the Court of Frederick II Hohenstaufen, ed. W. Tronzo (Studies in the History of Art, XLIV) (Washington, DC, 1994), 213-224. For earlier relevant scholarship, see W. Cohn-Breslau, "Kaiser Friedrich II. und die deutschen Juden," Monatsschrift für Geschichte und Wissenschaft des Judentums, LVIII (1919), 315-332; and J. Cohn, "Die Judenpolitik der Hohenstaufen" (Dissertation, Universität Hamburg, 1934).

72. J. Aronius, ed., with A. Dresdner and L. Lewinski, Regesten zur Geschichte der Juden im fränkischen und deutschen Reiche bis zum Jahre 1273 (Berlin, 1902; repr. Hildesheim, 1970), 206-209, Nos. 469, 472, 473 , and 474 .

73. For a thorough discussion of this case with further bibliography, see G. Langmuir, "Ritual Cannibalism," in Toward a Definition of Antisemitism (Berkeley, 1990), 263-281.

74. B. Diestelkamp, "Der Vorwurf des Ritualmordes gegen Juden vor dem Hofgericht Kaiser Friedrichs II. im Jahr 1236," in Religiöse Devianz: Untersuchungen zu sozialen, rechtlichen und theologischen Reaktionen auf religiöse Abweichung im westlichen und östlichen Mittelalter, ed. D. Simon (Frankfurt, 1990), 19-39.

75. MGH, Const. et acta publica (Legum Sectio IV), II, 274-276 (No. 204); English trans. R. Chazan, ed., Church, State and Jew in the Middle Ages (New York, 1980), 123-126; modern German translation with further references in K. van Eickels and T. Brüsch, eds., Kaiser Friedrich II.: Leben und Persönlichkeit in Quellen des Mittelalters (Düsseldorf, 2000), 317-321.

76. For the 1157 charter, see Chazan, Church, State and Jew, 63-66. For a broad discussion of Jewish legal status in the empire throughout the high Middle Ages, see G. Kisch, The Jews in Medieval Germany: A Study of Their Legal and Social Status, 2nd ed. (New York, 1970), 129-168.

77. On this ruling, see F. Lotter, "Geltungsbereich und Wirksamkeit des Rechts der kaiserlichen Judenprivilegien im Hochmittelalter," Aschkenas, I (1991), 23-64, esp. 36-37; and A. Patschovsky, "Das Rechtsverhältnis der Juden zum deutschen König (9.-14. Jahrhundert)," Zeit- schrift der Savigny-Stiftung für Rechtsgeschichte, CX (1993), 331-371, at $355-366$

78. See H. Fischer, Die verfassungsrechtliche Stellung der Juden in den deutschen Städten während des 13. Jahrhunderts (Breslau, 1931; rpt. Aalen, 1969), 3-7; S. Grayzel, The Church and the Jews in the XIIIth Century, rev. (New York, 1966), 348-351; Kisch, The Jews in Medieval Germany, 133-135 and 143-153; S. W. Baron, A Social and Religious History of the Jews, IX, Under Church and Empire, 2nd ed. (New York, 1965), 135-192; J. F. Battenberg, "Des Kaisers Kammerknechte: Gedanken zur rechtlich-sozialen Situation der Juden in Spätmittelalter und früher Neuzeit," Historische Zeitschrift, CCXLV/3 (1987), 545-599; D. Willoweit, "Vom Königsschutz zur Kammerknechtschaft: Anmerkungen zum Rechtsstatus der Juden im Hochmittelalter," in Geschichte und Kultur des Judentums: eine Vorlesungsreihe an der JuliusMaximilians-Universität Würzburg, ed. K. Müller and K. Wittstadt (Würzburg, 1988), 71-89; Lotter, "Geltungsbereich und Wirksamkeit"; and Patschovsky, "Das Rechtsverhältnis."

79. This is the fundamental argument in J. A. Watt, "The Jews, the Law, and the Church: The Concept of Jewish Serfdom in ThirteenthCentury England," in The Church and Sovereignty, c. 590-1918: Essays in Honour of Michael Wilks, ed. D. Wood (Oxford, 1991), 153172. The focus of Watt's article, however, is England, not Germany.

80. See Simonsohn, The Apostolic See and the Jews, 96-102; as well as G. Dahan, Les intellectuels chrétiens et les juifs au moyen âge (Paris, 1990), 9, 396, 518-519, and passim.

81. Augustine, De civitate Dei, XVI, 37; The City of God against the Pagans, trans. R. W. Dyson (Cambridge, 1998), 751-753, at 753. See also St. Augustine, Treatises on Marriage and Other Subjects, trans. C. T. Wilcox et al. (Fathers of the Church, XXVII) (New York, 1955), 402-405; B. Blumenkranz, "Augustin et les juifs, Augustin et le judaïsme," Recherches augustiniennes, I (1958), 225-241, esp. 234; idem, Die Judenpredigt Augustins: ein Beitrag zur Geschichte der jüdisch-christlichen Beziehungen in den ersten Jahrhunderten (Basel, 1946; rpt. Paris, 1973), 164-175, esp. 169-171; and the commentary on both Augustine and Blumenkranz in P. Fredriksen, "Divine Justice and Human Freedom: Augustine on Jews and Judaism, 392-398," in From Witness to Witchcraft: Jews and Judaism in Medieval Christian Thought, ed. J. Cohen (Wiesbaden, 1996), 29-54.

82. R. I. Moore, Formation of a Persecuting Society: Power and Deviance in Western Europe, 950-1250 (Oxford, 1987); idem, "Anti-Semitism and the Birth of Europe," in Christianity and Judaism, ed. D. Wood (Studies in Church History, XXIX) (Oxford, 1992), 33-57.

83. Recent key works on the vast topic of Christian notions of Jews and Judaism are G. Langmuir, Toward a Definition of Antisemitism (Berkeley, 1990); J. Cohen, The Friars and the Jews; idem, Living Letters of the Law: Ideas of the Jew in Medieval Christianity (Berkeley, 1999); idem, From Witness to Witchcraft; R. Chazan, Medieval Stereotypes and Modern Antisemitism (Berkeley, 1997); A. S. Abulafia, Christians and Jews: The Twelfth-Century Renaissance (New York, 1995); eadem, ed., Religious Violence between Christians and Jews: Medieval Roots, Modern Perspectives (Houndmills, UK, 2002); T. H. Bestul, Texts of the Passion: Latin Devotional Literature and Medieval Society (Philadelphia, 1996); D. Nirenberg, Communities of Violence: Persecution of Minorities in the Middle Ages (Princeton, 1996); G. Dahan, The Christian Polemic against the Jews in the Middle Ages, trans. J. Gladding (Notre Dame, IN, 1998); M. Rubin, Gentile Tales: The Narrative Assault on Late Medieval Jews (New Haven, 1999); M. A. Signer and J. Van Engen, eds., Jews and Christians in Twelfth-Century Europe (Notre Dame, IN, 2001); L. Lampert, Gender and Jewish Difference from Paul to Shakespeare (Philadelphia, 2004); and S. F. Kruger, The Spectral Jew: Conversion and Embodiment in Medieval Europe (Minneapolis, 2006). 
84. At its highest point the tympanum only reaches $1.44 \mathrm{~m}$, and the widest point at the base is $2.9 \mathrm{~m}$. See Boeck, Der Bamberger Meister, 192 note 122. For the height of Synagoga, see ibid., 197 note 258.

85. This aspect of Synagoga at Bamberg (as well as at other early-thirteenthcentury sites) has been noted by generations of scholars. See, for example, Jantzen, Deutsche Bildhauer, 150-153; and Suckale, "Die Bamberger Domskulpturen," 56.

86. See note 100 below.

87. The face of the Devil was heavily restored in 1881 (see Schuller, Das Fürstenportal, 40). An ever-expanding bibliography treats medieval Christian representations of Jews. Noteworthy studies are B. Blumenkranz, Juden und Judentum in der mittelalterlichen Kunst (Stuttgart, 1965); E. M. Zafran, "The Iconography of Antisemitism: A Study of the Representation of the Jews in the Visual Arts of Europe, 14001600" (Dissertation, Institute of Fine Arts, New York University, 1973); W. P. Eckert, “'Von Niedrigkeit umglänzt ihr reines Bildnis': Antijudaismus in der christlichen Kunst; zur Darstellung von Juden und Judentum in christlichen Kunstwerken des Mittelalters und des Barock," in Antisemitismus: Erscheinungsformen der Judenfeindschaft gestern und heute, ed. G. B. Ginzel (Bielefeld, 1991), 358-388; Vienna, Jüdisches Museum der Stadt Wien, Die Macht der Bilder: Antisemitische Vorurteile und Mythen (Vienna, 1995), ed. E. Klamper; R. Mellinkoff, Outcasts: Signs of Otherness in Northern European Art of the Late Middle Ages, 2 vols. (Berkeley, 1993); H. Schreckenberg, The Jews in Christian Art: An Illustrated History (New York, 1996); D. Hassig, "The Iconography of Rejection: Jews and Other Monstrous Races," in Image and Belief: Studies in Celebration of the Eightieth Anniversary of the Index of Christian Art, ed. C. Hourihane (Princeton, 1999), 2545; S. Lipton, Images of Intolerance: The Representation of Jews and Judaism in the "Bible moralisée" (Berkeley, 1999); D. H. Strickland (formerly Hassig), Saracens, Demons, and Jews: Making Monsters in Medieval Art (Princeton, 2003); M. Merback, "Fount of Mercy, City of Blood: Cultic Anti-Judaism and the Pulkau Passion Altarpiece," $A B$, LXXXVII/4 (2005), 589-642; and idem, Beyond the Yellow Badge. Two important new publications deal with both Jewish cultural production and Christian images of Jews: E. Frojmovic, ed., Imagining the Self, Imagining the Other: Visual Representation and Jewish-Christian Dynamics in the Middle Ages and Early Modern Period (Leiden, 2002); and Speyer, Historisches Museum der Pfalz Speyer, Europas Juden im Mittelalter (Ostfildern-Ruit, 2004), ed. A Haverkamp et al., and published simultaneously in English as The Jews of Europe in the Middle Ages (Ostfildern-Ruit, 2004), ed. A Haverkamp et al.

88. For example, Sciurie, "Ecclesia und Synagoge: Bilder von Sinnlichkeit und Gewalt," 247-249.

89. On the Jewish quarter in relation to the topography of Bamberg in general, see H. Paschke, Der Judenhof und die alte Judengasse zu Bamberg (Bamberg, 1969), 3-4; and Schimmelpfennig, Bamberg im Mittelalter, 22-23.

90. Relevant discussions of varying quality are found in A. Eckstein, Geschichte der Juden im ehemaligen Fürstbistum Bamberg (Bamberg, 1898; rpt. Bamberg, 1985); I. Elbogen, A. Freimann, and H. Tykocinski', eds., Germania Judaica, I, Von den ältesten Zeiten bis 1238 (Tübingen, 1963), 18-22; H. Friedrich-Brettinger, Die Juden in Bamberg (Bamberg, 1962), 5-8; K. Geissler, Die Juden in Deutschland und Bayern bis zur Mitte des vierzehnten Jahrhunderts (Munich, 1976), 34; Schimmelpfennig, Bamberg im Mittelalter, 86-87; and M. Toch, "The Formation of a Diaspora: The Settlement of Jews in the Medieval German Reich," Aschkenas, VII/1 (1997), 55-78.

91. Aronius, Regesten, 94, No. 204.

92. Ibid., 131, No. 307.
93. Ibid., 64-65, No. 152. Other sources pertaining to Jews in Bamberg in the thirteenth century are found in ibid., 262, No. 623 , and the references in note 96 below.

94. The bathhouse is first recorded in documents from 1354 and 1361 but may have existed earlier. See Schimmelpfennig, Bamberg im Mittelalter, 170, Table XII. In 1355 the Bamberg synagogue was converted to a church dedicated to the Virgin and possibly rebuilt. Today it is a youth center. See Paschke, Der Judenhof, 3-4; and R. Krautheimer, Mittelalterliche Synagogen (Berlin, 1927), 181-186. On the history of the dance hall (which simply presumes its existence in the thirteenth century), see Paschke, Der Judenhof, 15-18.

95. Elbogen, Freimann, and Tykocinski, Germania Judaica, 18-19; Eckstein, Geschichte der Juden, 140-144; and L. Zunz, Zur Geschichte und Literatur (Berlin, 1845), I, 34, 42-43, 101, and 193.

96. A document from 1216 tells of a Jew from Boppard who bought a plot of land from the Bamberg church (Aronius, Regesten, 180, No. 404). A document from 1253 reports that the Bamberg monastery of Saint Michaelsberg had to sell land to meet the interest charged by a Jew to whom the foundation had pawned a church vestment (ibid., 254, No. 594). A document from 1257 again deals with Saint Michaelsberg. This time the abbey pawned a book with a luxury binding to a Jew (ibid., 264-265, No. 629). For similar cases, see ibid., 288-289, No. 699, 309, No. 732. Art historians have yet to explore the intimate relation between ecclesiastical indebtedness to Jews and the profusion of church building projects in the thirteenth century.

97. For the limits of episcopal municipal authority, see Schimmelpfennig, Bamberg im Mittelalter, 40-41 and 83-84.

98. Extant records of Jewish taxation in Bamberg date only to the fourteenth century and later. See Friedrich-Brettinger, Die Juden in Bamberg, 7. For classic investigations of taxation of Jews in Germany, see I. Rösel, "Die Reichssteuern der deutschen Judengemeinden von ihren Anfängen bis zur Mitte des 14. Jahrhunderts," Monatsschrift für Geschichte und Wissenschaft des Judentums, LIII (1909), 697-708; and LIV (1910), 55-69, 206-223, 333-347, and 462-473; and O. Stobbe, Die Juden in Deutschland während des Mittelalters in politischer, socialer und rechtlicher Beziehung (Braunschweig, 1866; rpt. Amsterdam, 1968), 27-39.

99. For an introduction to the positions of the Fourth Lateran Council concerning Jews, with source texts, see Marcus, The Jew in the Medieval World, 137-141. For all canons of the council with brief commentary, see Tanner, Decrees of the Ecumenical Councils, 227-271.

100. Grayzel, The Church and the Jews, 306-309, No. IX; and Chazan, Church, State, and Jew, 197-198. There is a vast bibliography on Jews and the money trades in the high Middle Ages. For an introduction with further sources, see Lipton, Images of Intolerance, 30-53.

101. Grayzel, The Church and the Jews, 310-311, No. XI.

102. Ibid., 308-309, No. X; L. I. Newman, "Intermarriage between Jews and Christians during the Middle Ages," Jewish Institute Quarterly, II/2 (1926), 2-8, and II/3 (1926), 22-28; and J. A. Brundage, "Intermarriage between Christians and Jews in Medieval Canon Law," Jewish History, III/1 (1988), 25-40. On distinguishing marks for Jews, see G. Kisch, "The Yellow Badge in History," Historia Judaica, IV/2 (1942), 95-144; idem, The Jews in Medieval Germany, 295-299; A. Cutler, "Innocent III and the Distinctive Clothing of Jews and Muslims," Studies in Medieval Culture, III (1970), 92-116, esp. 106-112 and note 58; W. Pakter, Medieval Canon Law and the Jews (Ebelsbach, 1988), 292-301; and Simonsohn, The Apostolic See and the Jews, 135-138, with further references.

103. On the proximity of the Jewish street to the cathedral, see sources in note 89 above. 
104. S. Salfeld, Das Martyrologium des Nürnberger Memorbuches (Berlin, 1898), 148; and Elbogen, Friemann, and Tykocinski, Germania Judaica, 18

105. On Jews and Satan, see J. Trachtenberg, The Devil and the Jews: The Medieval Conception of the Jew and Its Relation to Modern Antisemitism (New Haven, 1943; rpt. Philadelphia, 1983), esp. 11-31; F. Raphaël, "Le juif et le diable dans la civilisation de l'occident," Social Compass, XIX/4 (1972), 549-566; J. Y. Gregg, Devils, Women and Jews: Reflections of the Other in Medieval Sermon Stories (Albany, NY, 1997); and Strickland, Saracens, Demons, and Jews, 61-78.

106. I owe this observation to one of the anonymous reviewers of this article.

107. This gesture is made by figures at Notre-Dame and Saint-Germain l'Auxerrois in Paris, the west choir at Naumburg, and the cathedral of Mießen, among other places. I owe these comparisons to W. Sauerländer, "Les statues royales du transept de Reims," RdA, XXVII (1975), 9-30. On regal and noble gestures in general, see J.-C. Schmitt, La raison des gestes dans l'occident médiéval (Paris, 1990), 229-232; and A. Nitschke, Körper in Bewegung: Gesten, Tänze und Räume im Wandel der Geschichte (Stuttgart, 1989), 232-239.

108. Among many possible examples is the image in a ca. 1230 Parisian Psalter, Blackburn Museum and Art Gallery, MS 20960, fol. 3v (reproduced in M. Camille, The Gothic Idol: Ideology and Image-Making in Medieval Art [Cambridge, 1989], fig. 1).

109. Though some scholars argue that the Bamberg Rider originally was installed elsewhere in the cathedral, Walter Hartleitner, following extensive technical investigation, maintains that the figure today resides in its original setting (see references in note 114 below). For a dissenting argument maintaining the Rider was moved to the site where it is today only after the Middle Ages, see Suckale, "Die Bamberger Domskulpturen," 62. For a summary of earlier scholarship on this question, see J. Traeger, "Der verschollene Name: zur Deutungsgeschichte des Bamberger Reiters," Zeitschrift des deutschen Vereins für Kunstwissenschaft, XLIX-L (1995-1996), 44-76, at 44-47. Further sculptures of the Virgin, a Sibyl, St. Denis, and an angel now are installed on the north side of the east choir. Scholars agree that few of these figures are in the spots for which they originally were designed, and thus they remain outside the scope of this investigation.

110. See R. Baumgärtel-Fleischmann, Die Altäre des Bamberger Domes von 1012 bis zur Gegenwart (Bamberg, 1987); and eadem, "Der Bamberger Dom: die Umgestaltungen des Innenraums und die Entwicklung der festen Ausstattung bis zum Ende des Mittelalters," in Heiliger Raum: Architecktur, Kunst und Liturgie in mittelalterlichen Kathedralen und Stiftskirchen, ed. F. Kohlschein and P. Wünsche (Münster, 1998), 59-99.

111. Kroos, "Liturgische Quellen zum Bamberger Dom," 115-122; and the more developed investigation in Baumgärtel-Fleischmann, "Der Bamberger Dom," 93-94.

112. It is worth noting that for many feasts, altars in the nave and aisles were chief sites for celebration of the Mass. See Wünsche, "Die Kathedrale als heilige Stadt"; Baumgärtel-Fleischmann, Die Altäre; and eadem, "Der Bamberger Dom."

113. On the chin-length wavy bob as a hairstyle specifically associated with secular nobility, see J. Bumke, Courtly Culture: Literature and Society in the High Middle Ages, trans. T. Dunlap (Berkeley, 1991), 149.

114. A summary of the latest findings on the Bamberg Rider is found in A. Hubel, "Reiterfigur," in Bamberg, Kaiser Heinrich II., 1002-1024, 402-405, No. 214. See also W. Hartleitner, "Zur Polychromie des Bamberger Reiters," in Passau, Oberhaus Museum der Stadt Passau, Bayern-Ungarn: Tausend Jahre (Regensburg, 2001), ed. W. Jahn, C. Lankes, W. Petz, and E. Brockhoff, 21-24; and idem, "Zur Polychromie der Bamberger Domskulptur," 371-373. For some of Hartleit- ner's findings, see www.historisches-franken.de/bamreiter/reiter02.htm. For an earlier assessment, see Suckale, "Die Bamberger Domskulpturen," 32 and 74 note 26 .

115. A new study analyzes the traces of paint left at the time of the nineteenthcentury restoration of the cathedral (see note 23 above): C. HansSchuller, Der Bamberger Dom: seine "Restauration." See also J. Zink, "Der Bamberger Dom und seine plastiche Ausstattung bis zur Mitte des 13. Jahrhunderts," Kunstchronik, XXVIII/11 (1975), 387-405, at 395; and W. Haas, "Die Raumfarbigkeit des Bamberger Domes," Deutsche Kunst und Denkmalpflege, XXXVI (1978), 21-36, esp. 22-24.

116. Kroos, "Liturgische Quellen zum Bamberger Dom," 138-142. See also F. Kohlschein, "Der Bamberger Dom als Ort für das "Fest des Glaubens," " in Dieses große Fest aus Stein: Bamberger Dom-Lesebuch zum 750. Weihejubiläum, ed. H.-G. Röhrig (Bamberg, 1987), 285-325.

117. The faces described here are painted directly on the pink paint of the vaults - that is, there is no trace of dirt between the ground paint layer and the paint of the faces. Thus, it seems that these faces were painted on the ceiling at the cathedral's construction in the 1230s. See Haas, "Die Raumfarbigkeit," 25.

118. See references in note 87 above.

119. Pope Clement II's tomb arguably is a further component of the image environment centered on the Fürstenportal. But because this coffin's adornment is unrelated to the Jewish themes explored here, it remains outside the scope of this investigation. For the latest on this tomb, see the essays in L. Göller, ed., Clemens II.: der Papst aus Bamberg, 24. Dezember 1046-9. Oktober 1047 (Bamberg, 1997). On the monumental crucifix, see J. Traeger, "Der Bamberger Reiter in neuen Sicht," ZfKg, XXXIII/1 (1970), 1-20.

120. For a useful summary of this literature, see Traeger, "Der verschollene Name." For more on the interpretation of this work, see L. Abramowski, "Der Bamberger Reiter: vom Endzeitkaiser zum heiligen König Stephan von Ungarn," Zeitschrift für Kirchengeschichte, XCVIII/4 (1987), 206229.

121. See Hubel, "Reiterfigur," with further references.

122. Some scholars contend that the Bamberg Rider alludes to Frederick II, casting the emperor as a modern incarnation of Constantine or St. George. See O. von Simson, "The Bamberg Rider," Review of Religion, IV/3 (1940), 257-281; and G. Ladner, "Die Anfänge des Kryptoporträts," in Michael Stettler zum 70. Geburtstag: von Angesicht zu Angesicht; Porträtstudien, ed. F. Deuchler, M. Flury-Lemberg, and K. Otavsky (Bern, 1983), 78-97.

123. Similarities between the face of the Rider and contemporary French representations of kings make plain the unlikelihood that the Bamberg figure replicates the physiognomic specifics of Frederick's face. For a related argument on monumental sculptures representing types rather than individuals, see W. Cahn, "The Tympanum of the Portal of SaintAnne at Notre Dame de Paris and the Iconography of the Division of the Powers in the Early Middle Ages," JWCI, XXXII (1969), 55-72. For recent discussions of likeness and portraiture in the premodern period, see G. S. Wright, "The Reinvention of the Portrait Likeness in the Fourteenth Century," Gesta, XXXIX/2 (2000), 117-134; T. Dale, "The Individual, the Resurrected Body, and Romanesque Portraiture: The Tomb of Rudolf von Schwaben in Merseburg," Speculum, LXXVII/3 (2002), 707-743; S. Perkinson, "Portraits and Counterfeits: Villard de Honnecourt and Thirteenth-Century Theories of Representation," in Excavating the Medieval Image: Manuscripts, Artists, Audiences; Essays in Honor of Sandra Hindman, ed. D. S. Areford and N. A. Rowe (Aldershot, UK, 2004), 13-35; and idem, "From 'Curious' to Canonical: Jehan Roy de France and the Origins of the French School," $A B$, LXXXVII/3 (2005), 507-532. On the question of likenesses of Frederick II in particular, see H. Buschhausen, "Probleme der 
Bildniskunst am Hof Kaiser Friedrichs II.," in Stauferzeit: GeschichteLiteratur-Kunst, ed. R. Krohn, B. Thum, and P. Wupnewski (Stuttgart, 1978), 220-243.

Other recent investigations of the Rider complement my own, though I depart from these scholars' definitive identifications of the sculpture with specific figures-the former with Henry II, the latter with the messiah as enemy of the Antichrist (as in Rev. 19:11-16): P. C. Claussen, "Kompensation und Innovation: zur Denkmalproblematik im 13. Jahrhundert am Beispiel der Reitermonumente in Magdeburg und Bamberg," in Studien zur Geschichte der europäischen Skulptur, ed. Beck and Hengevoss-Dürkop, I, 565-586, II, 316-331; and H. Möhring, König der Könige: der Bamberger Reiter in neuer Interpretation (Königstein im Taunus, 2004).

124. Mine is not the first study to consider the Rider in relation to other sculptures inside and outside the cathedral. See the works cited in notes $114,119,120,122$, and 123 above. A recent discussion argues that the Rider functions as witness, drawing attention to the cathedral's chief relics, the tombs of SS. Henry and Kunigunde, by gazing at visitors paying honor to the saints' tombs in the nave. See M. Zerbes, "Reiterskulptur," in Passau, Bayern-Ungarn: Tausende Jahre, 47-49, No. 1.14 .

125. For recent assessments with further bibliography, see V. R. Kaufmann, "Magdeburg Rider Group: State of Research and Preliminary Suggestions for Further Work," in Der Magdeburger Dom: ottonische Gründung und staufischer Neubau, ed. E. Ullmann (Leipzig, 1989), 205-230; eadem, "Magdeburg Rider and the Law," in Kunst im Reich Kaiser Friedrichs II. von Hohenstaufen, ed. K. Kappel et al. (Munich, 1996), 127-136; and eadem, "The Magdeburg Rider: An Aspect of the Reception of Frederick II's Roman Revival North of the Alps," in Tronzo, Intellectual Life at the Court of Frederick II, 63-88. I thank Virginia Roehrig Kaufmann for sharing her work with me.

126. Kaufmann, "The Magdeburg Rider: An Aspect."

127. For example, Valentiner, The Bamberg Rider, 98-115; and Kaufmann, "Magdeburg Rider: An Aspect," 73-75.

128. See note 138 below.

129. For the Latin text with commentary, see K. Young, The Drama of the Medieval Church, rev. (Oxford, 1951), II, 369-396. For a thorough discussion with transcription, see G. Günther, Der Antichrist: der staufische Ludus de Antichristo (Hamburg, 1970). For modern English translations with commentary, see S. F. Barrow and W. H. Hulme, "Antichrist and Adam," Western Reserve University Bulletin, XXVIII/ 8 (1925), 5-32; and J. Wright, ed. and trans., The Play of Antichrist (Toronto, 1967). For a useful summary, see H. Möhring, Der Weltkaiser der Endzeit: Entstehung, Wandel und Wirkung einer tausenjährigen Weissagung (Stuttgart, 2000), 176-184. The text of the Ludus de Antichristo likely was written by a German cleric, but not necessarily a monk of Tegernsee (for relevance, see below), about 1160. For discussion of original authorship and description of the surviving manuscript, see ibid., 184; as well as Günther, Der Antichrist, 75-88.

130. Cf. Essen, Alte Synagoge, Ecclesia und Synagoga, 16. On Ecclesia, Synagoga, and liturgical drama in general, see Weber, Geistliches Schauspiel; and G. Lutz, "Die Darstellungen von Ecclesia und Synagoge und das geistliche Spiel im späten Mittelalter," Poznanskie Towarzystwo Przyjaciól Nauk, CIX (1991), 45-52, with further references.

131. A fragment of the text also survives in a twelfth-century Bible likely created at Tegernsee, then housed at the monastery of Saint Georgenberg in Tirol. See J. Riedmann, "Ein neuaufgefundenes Bruchstück des 'Ludus de Antichristo': Beiträge zur Geschichte der Beziehungen zwischen St. Georgenberg in Tirol und Tegernsee," Zeitschrift für bayerische Landesgeschichte, XXXVI (1973), 16-38.

132. For discussion of the Andechs-Meran clan giving gifts to the Tegernsee house, see A. Schütz, "Das Geschlecht der Andechs-Meranier im europäischen Hochmittelalter," in Kloster Andechs, Herzöge und Heilige, 21129 , at $113-115$.

133. For the letter that suggests this connection, see Die Tegernseer Briefsammlung des 12. Jahrhunderts, ed. H. Plechl (Hannover, 2002), 321322 , No. 290. I thank Jonathan Lyon for bringing this source to my attention. For discussion, see Schütz, "Das Geschlecht der AndechsMeranier," 117-118, with references to debate over this question.

134. The codex is relatively small $(11.3 \mathrm{by} 16 \mathrm{~cm})$, on rough parchment filled with holes (many of them sewn up), is wholly unadorned, and is filled with abbreviations and scribal errors, some of which are corrected in a thirteenth- or fourteenth-century hand. For a full description of the manuscript and its contents, see H. Plechl, "Die Tegernseer Handschrift Clm 19411: Beschreibung und Inhalt," Deutsches Archiv für Erforschung des Mittelalters, XVIII/1 (1962), 418-501.

135. "prophetarum eximius rex David in premissa auctoritate de duobus imperatoribus prophetavit, videlicet de celesti imperatore, qui ventis et mari imperat, qui dixit et facta sunt, mandavit et creata sunt universa, et de terrestri domino $\mathrm{Fr}$ [iderico] imperatore magnifico uncto oleo leticie pre regibus universis; primo prophetavit de filio, secundario de successore in regnum." R. M. Kloos, "Nikolaus von Bari, eine neue Quelle zur Entwicklung der Kaiseridee unter Friedrich II.," Deutsches Archiv für Erforschung des Mittelalters, XI/1 (1954), 166-190, at 169 (rpt. in Stupor Mundi: zur Geschichte Friedrichs II. von Hohenstaufen, ed. G. Wolf [Darmstadt, 1982], 130-159, at 134).

136. For an expansive examination of the tension between fantasy and reality in the rule of Frederick II, see A. Sommerlechner, Stupor Mundi? Kaiser Friedrich II. und die mittelalterliche Geschichtsschreibung (Vienna, 1999). For an overview of the stories circulated about the Staufen (both pro and con), see K. Schreiner, "Die Staufen in Sage, Legende und Prophetie," in Stuttgart, Württembergisches Landesmuseum, Die Zeit der Staufer: Geschichte-Kunst-Kultur (Stuttgart, 1977), III, 249262. For useful discussions of the numinous notion of Frederick II, see H. M. Schaller, "Die Kaiseridee Friedrichs II," in Stauferzeit: ausgewählte Aufsätze (Hannover, 1993), 53-83; and idem, "Das Relief an der Kanzel der Kathedrale von Bitonto: ein Denkmal der Kaiseridee Friedrichs II.," Stauferzeit, 1-23.

137. E. Kantorowicz, "The 'King's Advent' and the Enigmatic Panels in the Doors of Santa Sabina," $A B$, XXVI/1 (1944), 207-231, esp. 209-211. This article also offers examples of ancient and medieval images of rulers accompanied by feminine personifications of Victory and other triumphal motifs, suggesting the lexicon of forms to which the Rider-EcclesiaSynagoga trio is related structurally.

138. On these tropes, see B. McGinn, Visions of the End: Apocalyptic Traditions in the Middle Ages (New York, 1998), 82-87, 117-121, and 168179; as related to Frederick II, see H. M. Schaller, "Endzeit-Erwartung und Antichrist-Vorstellungen in der Politik des 13. Jahrhunderts," in Stauferzeit, 25-52; and F. Shaw, "Friedrich II as the "Last Emperor," German History, XIX/3 (2001), 321-339.

139. The court of England, for the moment supporters of the Staufen, also promoted the notion that Frederick was special agent of the Lord, restoring the Holy Land to Christianity. See the account of Frederick's crusade in the chronicle of Roger of Wendover (d. 1236), Flores historiarum, rpt. in Eickels and Brüsch, Kaiser Friedrich II., 173-179. 